\title{
OS RECURSOS HÍDRICOS E O ZONEAMENTO AMBIENTAL: O CASO DO MUNICÍPIO DE SÃO CARLOS (SP)
}

\author{
Marcelo Montaño
}

Dissertação apresentada à Escola de Engenharia de São Carlos da Universidade de São Paulo, como parte dos requisitos para a obtenção do título de Mestre em Hidráulica e Saneamento

ORIENTADOR: Prof. Dr. Marcelo Pereira de Souza

São Carlos

2002 


\section{AGRADECIMENTOS}

Ao Prof. Marcelo Pereira de Souza, pela orientação fornecida durante a elaboração deste trabalho e, acima de tudo, pela amizade construída ao longo destes anos de convivência.

Ao Conselho Nacional de Desenvolvimento Científico e Tecnológico - CNPq, pela bolsa de estudo concedida.

Aos funcionários do Departamento de Hidráulica e Saneamento, e do Centro de Recursos Hídricos e Ecologia Aplicada, pela disposição e dedicação.

A todos os colegas do Lab, especialmente ao Vitão (eterno presidente da Acquavit), Aldo (Pexe) e Aurélio, que interferiram de forma mais direta no andamento do trabalho.

Aos meus pais, Raul e Neide, e todo o resto da família, pelo apoio irrestrito e incondicional oferecido.

À galera da banda, Gabriel, Gustavo e Celsinho, pela válvula de escape oferecida. Aos grandes amigos de sanca: Gordo, TG, Gorpeta, também extremamente valiosos, no final das contas.

À Crau e ao Chicão, pelos novos caminhos oferecidos para toda a vida. E isto é apenas o começo..... 


\section{SUMÁRIO}

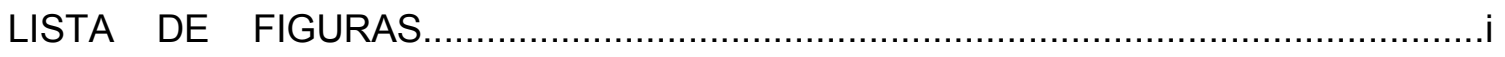

LISTA DE TABELAS ............................................................................ ii

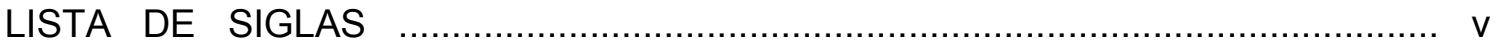

RESUMO

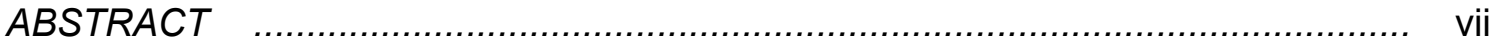

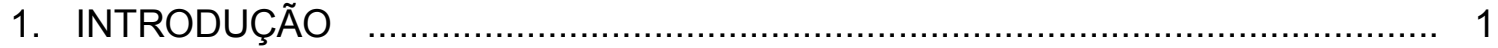

1.1. A gestão ambiental e os recursos hídricos ............................................... 4

1.2. Viabilidade ambiental, caracterização ambiental e capacidade suporte

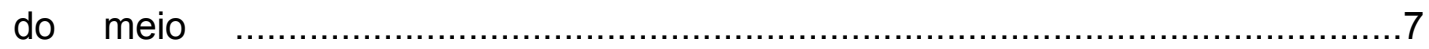

1.3. Desenvolvimento sustentável ............................................................... 8

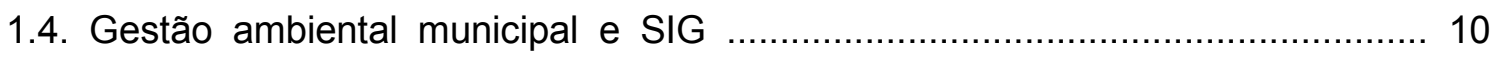

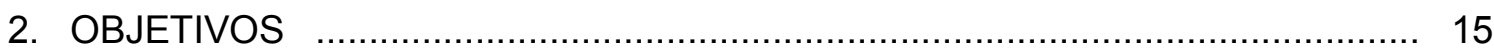

3. ZONEAMENTO ECOLÓGICO-ECONÔMICO (ZEE), ZONEAMENTO ……….......

AMBIENTAL E OS RECURSOS HÍDRICOS ……........................................16

3.1. O Zoneamento Ecológico-Econômico (ZEE) …………………................... 18

3.2. O zoneamento ambiental ................................................................ 20

3.2. Aplicações do zoneamento ambiental .................................................... 23

3.3. O zoneamento ambiental e os recursos hídricos ........................................ 27

4. MATERIAIS E MÉTODOS ……........................................................ 32

4.1. Caracterização da área de estudo ......................................................... 32

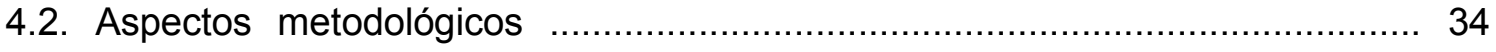

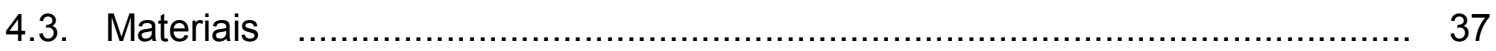

4.4. A elaboração do zoneamento ambiental .................................................. 38 
4.4.1. Suscetibilidade à erosão ............................................................... 40

4.4.2. Risco de contaminação de águas subterrâneas ...................................... 41

4.4.3. Risco de assoreamento dos corpos d'água superficiais ......................... 46

4.4.4. Determinação da aptidão para a instalação de atividades industriais ...... 48

4.4.4.1. Ponderação sobre os recursos hídricos ...................................... 51

4.4.4.2. Caracterização das atividades ..................................................... 58

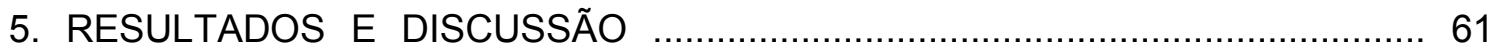

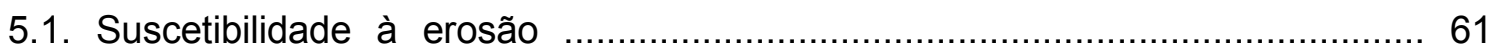

5.2. Risco de contaminação de águas subterrâneas ........................................... 64

5.3. Risco de assoreamento dos corpos d'água superficiais ............................... 66

5.4. Determinação da aptidão para a instalação de atividades industriais ............. 68

5.4.1. Ponderação sobre os recursos hídricos ............................................ 71

5.4.1.1. Indústria do TIPO 1 (indústria têxtil) ……….................................. 72

5.4.1.2. Indústria do TIPO 2 (suco de laranja) .......................................... 77

5.4.1.3. Estação de Tratamento de Esgotos (ETE) ……….......................... 82

5.4.1.4. Captação de água para abastecimento …………………………... 86

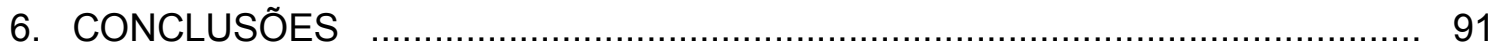

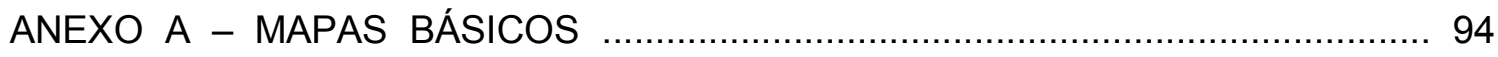

ANEXO B - PLANOS INTERMEDIÁRIOS DE INFORMAÇÃO .......................... 101

ANEXO C - MAPAS-SÍNTESE DE VULNERABILIDADES E APTIDÕES ........... 106

REFERÊNCIAS BIBLIOGRÁFICAS ........................................................... 121 


\section{LISTA DE FIGURAS}

FIGURA 1: Tipologia $x$ Localização …………................................................ 8

FIGURA 2: Localização do município de São Carlos em relação ao

Estado de São Paulo ....................................................................... 32

FIGURA 3: Unidades de Gerenciamento de Recursos Hídricos às quais pertence o município de São Carlos ………………................................. 34

FIGURA 4: esquema de execução do trabalho …………………………….... 36

FIGURA 5: Diagrama de execução do estudo de zoneamento ambiental efetuado

FIGURA 6: Diagrama esquemático para a determinação do risco de assoreamento dos corpos d'água superficiais

FIGURA 7: Esquema ilustrando o procedimento para a avaliação da aptidão para a instalação de empreendimentos industriais 50

FIGURA 8: Sub-bacias consideradas para a elaboração do estudo de caso 52

FIGURA 9: Mapa síntese de suscetibilidade à erosão para o município de

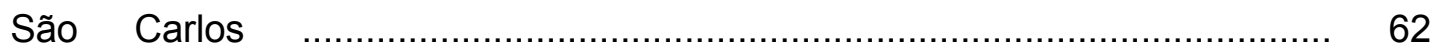

FIGURA 10: Detalhe da região do bairro Cidade Aracy .......................................63

FIGURA 11: Mapa síntese de risco de contaminação de águas subterrâneas ....... 65

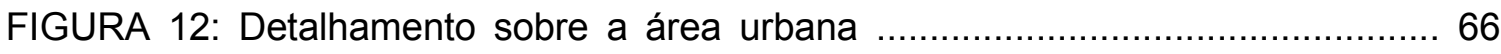

FIGURA 13: Risco de assoreamento dos corpos d'água .................................... 67

FIGURA 14: Plano de informação Aptidão1 ………………………………….... 69

FIGURA 15: Aptidão p/ a instalação de empreendimentos .................................. 70

FIGURA 16: Áreas consideradas aptas para a instalação do empreendimento Indústria TIPO 1, associadas às aptidões apresentadas pelas sub-bacias em que se localizam, considerando a vazão $Q_{\text {méd }}$.................................... 75

FIGURA 17: Áreas consideradas aptas para a instalação do empreendimento Indústria TIPO 1, associadas às aptidões apresentadas pelas sub-bacias em que se localizam, considerando as vazões $Q_{95}$ e $Q_{7,10}$ 
FIGURA 18: Áreas consideradas aptas para a instalação do empreendimento Indústria TIPO 2, associadas às aptidões apresentadas pelas sub-bacias

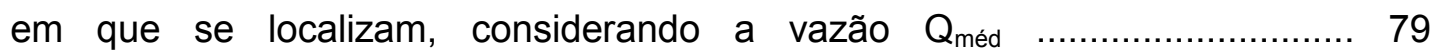

FIGURA 19: Áreas consideradas aptas para a instalação do empreendimento Indústria TIPO 2, associadas às aptidões apresentadas pelas sub-bacias

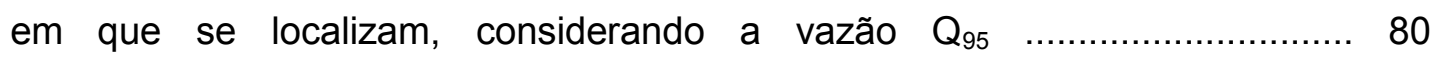

FIGURA 20: Áreas consideradas aptas para a instalação do empreendimento Indústria TIPO 2, associadas às aptidões apresentadas pelas sub-bacias

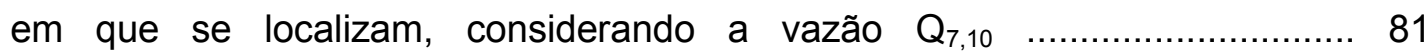

FIGURA 21: Áreas consideradas aptas para a instalação do empreendimento Estação de Tratamento de Esgotos, associadas às aptidões apresentadas pelas sub-bacias em que se localizam, considerando a vazão $Q_{\text {méd }}$

FIGURA 22: Áreas consideradas aptas para a instalação do empreendimento Estação de Tratamento de Esgotos, associadas às aptidões apresentadas pelas sub-bacias em que se localizam, considerando a vazão $Q_{95}$

FIGURA 23: Áreas consideradas aptas para a instalação do empreendimento Estação de Tratamento de Esgotos, associadas às aptidões apresentadas pelas sub-bacias em que se localizam, considerando a vazão $Q_{7,10}$ 86

FIGURA 24: Áreas aptas para a instalação de empreendimentos sobre aptidão para captação de água para abastecimento, para a vazão $Q_{\text {méd }}$ 88

FIGURA 25: Áreas aptas para a instalação de empreendimentos sobre aptidão para captação de água para abastecimento, para a vazão $Q_{95}$ 


\section{LISTA DE TABELAS}

TABELA 1 - Ponderação aplicada para a determinação da suscetibilidade

à erosão

TABELA 2 - Ponderação adotada para o fator permeabilidade

TABELA 3 - Classes de vulnerabilidade para o fator espessura dos materiais, considerando-se a profundidade dos solos

TABELA 4 - Classes de vulnerabilidade adotadas para o fator substrato rochoso

TABELA 5 - Classes de vulnerabilidade adotadas para o fator declividade

TABELA 6 - Classes de vulnerabilidade adotadas para o fator densidade hidrográfica

TABELA 7 - Pesos atribuídos aos fatores considerados para estimar a vulnerabilidade do aqüífero

TABELA 8 - Ponderação para o fator pedologia 49

TABELA 9 - Ponderação para o fator declividade 49

TABELA 10 - Ponderação para o fator geologia 49

TABELA 11 - Vazões estimadas nos exutórios das sub-bacias consideradas 53

TABELA 12 - valores admitidos para OD e DBO para as classes dos corpos d'água

TABELA 13 - Classes de aptidão preliminar, em função dos índices para

DBO e OD estimados 56

TABELA 14 - Classes de aptidão em função dos índices para OD estimados 57

TABELA 15 - Classes de aptidão em função dos índices para OD crítico 57

TABELA 16 - Classes de aptidão em função do índice para a oferta 58

TABELA 17 - Valor das áreas obtidas para as diferentes classes de suscetibilidade à erosão encontradas

TABELA 18 - Risco de assoreamento para os corpos d'água do município 66

TABELA 19 - Classes de aptidão para as sub-bacias consideradas, em função dos valores para as concentrações iniciais de DBO e OD (atividade Indústria ... do TIPO 1), para o período de vazão $Q_{\text {méd }}$ 
TABELA 20 - Classes de aptidão para as sub-bacias consideradas, em função dos valores para as concentrações iniciais de DBO e OD (atividade Indústria ....

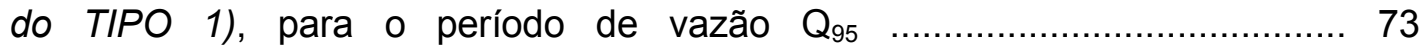

TABELA 21 - Classes de aptidão para as sub-bacias consideradas, em função dos valores para as concentrações iniciais de DBO e OD (atividade Indústria ....

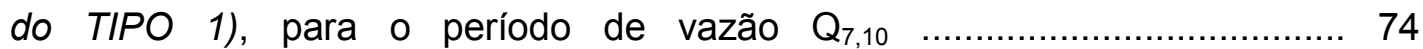

TABELA 22 - Classes de aptidão para as sub-bacias consideradas, em função dos valores para as concentrações iniciais de DBO e OD (atividade Indústria ....

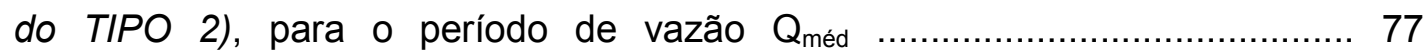

TABELA 23 - Classes de aptidão para as sub-bacias consideradas, em função dos valores para as concentrações iniciais de DBO e OD (atividade Indústria ....

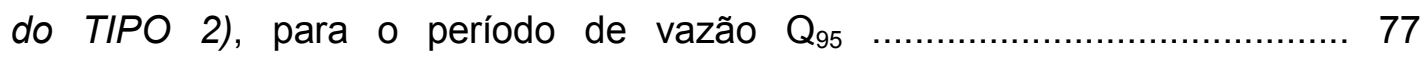

TABELA 24 - Classes de aptidão para as sub-bacias consideradas, em função dos valores para as concentrações iniciais de DBO e OD (atividade Indústria ....

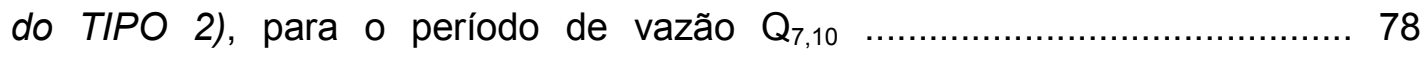

TABELA 25 - Classes de aptidão para as sub-bacias consideradas, em função dos valores para as concentrações iniciais de DBO e OD (atividade ETE),

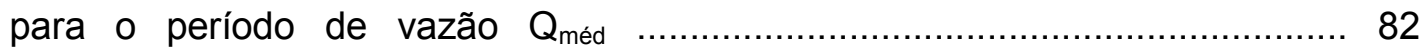

TABELA 26 - Classes de aptidão para as sub-bacias consideradas, em função dos valores para as concentrações iniciais de DBO e OD (atividade ETE),

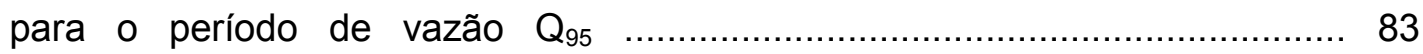

TABELA 27 - Classes de aptidão para as sub-bacias consideradas, em função dos valores para as concentrações iniciais de DBO e OD (atividade ETE), para o período de vazão $Q_{7,10}$ 83

TABELA 28 - Classes de aptidão para as sub-bacias consideradas, em função do índice para a oferta, obtido para o período de vazão $Q_{\text {méd }} \ldots . . .87$ TABELA 29 - Classes de aptidão para as sub-bacias consideradas, em função do índice para a oferta, obtido para o período de vazão $Q_{95}$ 87

TABELA 30 - Síntese das aptidões apresentadas pelo território do município frente às diferentes situações consideradas 
LISTA DE SIGLAS

APP - Área de Preservação Permanente

CETESB - Companhia de Tecnologia de Saneamento Ambiental

CPRM - Companhia de Pesquisa em Recursos Minerais (Serviço Geológico do Brasil)

DAEE - Departamento de Águas e Energia Elétrica

DBO - Demanda Bioquímica de Oxigênio

DEPRN - Departamento Estadual de Proteção aos Recursos Naturais

IBGE - Instituto Brasileiro de Geografia e Estatística

INPE - Instituto Nacional de Pesquisa Espacial

IPEA - Instituto de Pesquisa Econômica Aplicada

OD - Oxigênio Dissolvido

SAE - Secretaria de Assuntos Estratégicos da Presidência da República

SIG - Sistemas de Informação Geográfica

ZEE - Zoneamento Ecológico-Econômico 


\section{RESUMO}

MONTAÑO, M. (2002). Os recursos hídricos e o zoneamento ambiental: o caso do município de São Carlos (SP). São Carlos, 129 p. Dissertação (Mestrado). Escola de Engenharia de São Carlos, Universidade de São Paulo.

Dentre os mecanismos de planejamento à disposição do Poder Público passíveis de serem utilizados no planejamento territorial é possível perceber que, nos anos recentes, o zoneamento ambiental tem se destacado como um instrumento estratégico de planejamento regional, que busca a compatibilização entre o desenvolvimento econômico e a qualidade ambiental. O presente trabalho procura trazer subsídios para que se discuta a gestão ambiental a partir dos resultados oriundos da elaboração de um zoneamento ambiental que observe os preceitos estabelecidos pelo desenvolvimento sustentável, conjugando a procura do desenvolvimento econômico à observação das limitações impostas pelo meio ambiente. Tomando como área de estudo o município de São Carlos (SP), o trabalho apresenta algumas análises elaboradas para o território do município procurando-se determinar algumas das aptidões e suscetibilidades apresentadas pelos fatores ambientais em conjunto frente à eventual necessidade de instalação de alguns empreendimentos. Considerando os recursos hídricos como um fator ambiental relevante para a definição do local em que serão instalados, o trabalho apresenta uma proposta de ponderação, a ser inserida nos estudos de zoneamento ambiental, para a determinação da aptidão apresentada pelo território do município referente à instalação da atividade. Os resultados encontrados servem de base para uma discussão a respeito da definição de políticas de desenvolvimento mais apropriadas ao que talvez esteja se tornando um novo paradigma para a sociedade: a manutenção da qualidade ambiental.

Palavras-chave: gestão ambiental, zoneamento ambiental, recursos hídricos 


\section{ABSTRACT}

MONTAÑO, M. (2002). Water resources and the environmental zoning: the case of São Carlos municipality. São Carlos, 129 p. Dissertação (Mestrado). Escola de Engenharia de São Carlos, Universidade de São Paulo.

Considering the mechanisms available to be used on territorial planning, in recent years, the environmental zoning has been noted as a strategical regional-planning tool, in order to make compatible economical development and environmental quality. This work presents some information that can be used to discuss the environmental management, starting with the evaluation of the results obtained from an environmental zoning, that must include the concepts of sustainable development, searching for an economical growth that respects the environment's limitations. Taking as the study area the São Carlos municipality, located at São Paulo state, Brazil, this work presents some analysis made for the territory trying to determinate the feasibilities and susceptibilities presented by the environment, supposing the installation of different activities. As the factor water resources can be considered relevant to define the best place to install an activity, the work presents a ponderation to be inserted at environmental zoning studies to determine the territory's feasibility. The results are the basis for a discussion about the definition of development policies that are more appropriated under the point-of-view of a new paradigm: the environmental quality maintenance.

Keywords: environmental management, environmental zoning, water resources 


\section{INTRODUÇÃO}

Ao se discorrer sobre o papel do Poder Público na definição dos rumos a serem adotados de modo a se alcançar um nível satisfatório de desenvolvimento econômico e social, percebe-se de imediato a relevância das questões ambientais. Observa-se claramente que ao trato da questão ambiental, por afetar direta ou indiretamente todas as outras áreas da administração pública, deve ser atribuída uma grande importância no processo de desenvolvimento. Dessa maneira, seria desejável que se estabelecesse um relacionamento mais harmonioso entre o crescimento econômico e a qualidade ambiental.

Não se trata, entretanto, de adotar um posicionamento favorável ao meio ambiente ou ao desenvolvimento isolados mas, de maneira oposta, o que se propõe é que a escolha seja feita entre modos de desenvolvimento sensíveis ao meio ambiente. Esse, aliás, é um dos princípios encontrados na AGENDA 21, em que pode ser lido (princípio 4): "A fim de alcançar o Desenvolvimento Sustentável, a proteção do meio ambiente deverá constituir-se como parte integrante do processo de desenvolvimento e não poderá ser considerada de forma isolada" (SATO \& SANTOS, 1999, pág. 17).

Nas palavras de SACHS (1993), “(...) isso não significa que se deva buscar esse objetivo mediante a transformação de milhões de quilômetros quadrados de terra em parques nacionais ou reservas ecológicas de proteção absoluta, sem considerar as necessidades imediatas de populações locais e o potencial de ecodesenvolvimento dessas áreas" (pág. 27). Ao concluir o raciocínio, o autor ainda afirma que "o não-desenvolvimento não é, de modo algum, uma solução para o ‘mau-desenvolvimento”' (pág. 28).

É possível identificar, no aumento do interesse em relação às questões ambientais observado nas décadas mais recentes, a existência de um questionamento a modelos de desenvolvimento econômico que consideram a 
natureza somente como fonte de recursos a serem explorados, sem considerar a necessidade de sua conservação (BARBIERI, 1997; VIEIRA, 2001). Modos de organização econômica predadores dos recursos finitos da natureza revelam-se, cada vez mais, insustentáveis (CAVALCANTI, 2001). À medida em que novos conceitos e novos valores são incorporados pelos cidadãos, aumenta também a pressão exercida nos tomadores de decisão (decision makers - notadamente nesse caso, os participantes do Poder Público) para que seja adotada uma nova postura no trato das questões ambientais.

O Poder Público está, portanto, desafiado a pensar o desenvolvimento em harmonia com a natureza. Este desafio, nas palavras do sociólogo Herbert de Souza (SOUZA, 1992), estende-se na realidade "a todo o pensamento democrático, que deveria considerar o desenvolvimento de toda a humanidade como parte do próprio desenvolvimento da natureza e não como apropriador externo e predador de uma natureza vista única e exclusivamente como matéria-prima do desenvolvimento humano" (pág. 13).

Ao aceitar enfrentar este desafio é preciso que os atores envolvidos no processo decisório percebam, num primeiro momento, que a execução de políticas ambientais e econômicas sérias não são, de maneira alguma, mutuamente exclusivas (a bem da verdade, é praticamente impossível que uma decisão de ordem econômica possa ser tomada sem que traga implicações para o meio ambiente, e nenhuma alteração ambiental pode ocorrer sem que ocorra impacto na economia).

De acordo com BRANCO (1997), a verdadeira incompatibilidade situa-se entre a preservação do meio ambiente e o acúmulo privilegiado de riquezas, e não entre aquela e o desenvolvimento, pois "o desenvolvimento de uma nação não se faz amontoando riquezas: desenvolvimento é tudo o que traz felicidade a um povo, e não será feliz um povo que tiver suas matas destruídas, sua paisagem alterada e sua saúde corrompida".

Um outro aspecto a ser considerado por parte dos representantes do Poder Público, fundamental para o estabelecimento de um novo conjunto de políticas para o desenvolvimento, refere-se à necessidade de inclusão, no processo decisório, de fatores que busquem a manutenção e, se possível, a melhoria da qualidade do meio circundante. De acordo com CAVALCANTI (2001), "na montagem de uma 
sociedade sustentável, a política de desenvolvimento não poderia desprezar de modo algum as relações entre o Homem e a natureza que ditam o que é possível frente ao que é desejável" (pág. 25). Em outras palavras, se o que se procura é uma compatibilização entre o crescimento econômico e a qualidade ambiental condições essenciais para a sustentabilidade - as limitações impostas pelo meio ambiente devem ser consideradas (e observadas) pelos administradores, quando da implementação e execução de suas políticas de desenvolvimento econômico.

Dentre os diversos setores sobre quais o Poder Público tem o dever de atuar todos eles possuidores de uma importância destacada - e, considerando a necessidade de compatibilização entre o crescimento econômico e a qualidade ambiental, um dos mais importantes é o que trata do ordenamento territorial, por cuidar de uma questão básica ao desenvolvimento das atividades (qual seja, a definição dos locais em que estas atividades serão implantadas).

Responsável pelo disciplinamento do uso do solo e pela oferta de condições adequadas para a instalação dos empreendimentos, não cabe mais ao Poder Público aceitar que argumentos do tipo "geração de empregos" e "aumento de arrecadação", ainda que possuidores de um forte apelo nos dias atuais, justifiquem a inobservância das limitações impostas pelo meio ambiente. Mesmo porque, a inexistência de uma contabilidade que considere o valor dos bens e serviços ambientais $^{\text {t }}$ contribui de maneira significativa para que o raciocínio dos administradores públicos fique restrito ao aparente ciclo "aumento da capacidade produtiva-acumulação de capital-desenvolvimento econômico e social".

Sobre esse aspecto, aliás, o comentário de MERICO (1996) mostra que: “(..) grande parte dos problemas enfrentados pela humanidade estão interligados. Queda da produtividade econômica, queda da qualidade de vida e degradação do capital natural possuem vínculos muito estreitos" (pág. 142).

É um processo semelhante ao que ALMEIDA et al. (1999) denominam "crise dentro da crise". Para os autores, o atual modelo de desenvolvimento apresenta problemas na base energética de sustentação da produção, o que afeta o custo da

\footnotetext{
${ }^{1}$ Os bens ambientais podem ser representados pelos recursos naturais renováveis e não-renováveis (o capital natural). Como exemplo de serviços ambientais, podem ser citados o ciclo hidrológico, a ciclagem de nutrientes, a absorção de resíduos, enfim, a manutenção das condições propícias à vida - basicamente os serviços de fonte (suprimento de matérias-primas para a economia humana) e de fossa (absorção dos dejetos das sociedades).
} 
produção e a circulação no mercado dos bens e do capital. A crise econômica retroalimenta a crise energética, surgindo também a crise ambiental, desencadeada a partir da implantação do modelo econômico vigente, que se incorpora às outras duas, formando outro complexo interativo de retroalimentação crescente.

É necessário, portanto, uma rápida adequação do processo vigente, sobretudo, no que se refere à adoção de uma nova maneira de encarar o desenvolvimento, que incorpore a questão ambiental de maneira efetiva, que procure reduzir ao mínimo os impactos sobre o meio ambiente. Ao se refletir sobre a situação encontrada nas médias cidades brasileiras, percebe-se que as possibilidades de se efetuar uma gestão ambiental adequada ainda são bastante limitadas ou, nos casos em que é possível perceber o contrário, a mesma ainda é realizada de maneira incipiente, bastante tímida, talvez por não existir por parte do Poder Público um real comprometimento com o estabelecimento de um desenvolvimento que ocorra em bases efetivamente sustentáveis.

\subsection{A gestão ambiental e os recursos hídricos}

A água, um elemento fundamental à manutenção da vida, é um recurso essencial a todas as atividades humanas. Em países como o Brasil, infelizmente, um de seus usos mais freqüentes é como corpo receptor (e depurador) de resíduos.

Em condições de abundância e uso pouco intensivo, são desnecessários maiores cuidados com o controle, em termos de quantidade e qualidade. Porém, quando em situações de escassez relativa, essa medida precisa ser exercida considerando o controle do regime de uso, da poluição, da erosão do solo e do assoreamento (BARTH et al., 19872 apud LIMA, 1997).

Um conjunto de procedimentos organizados que visam atender às demandas de água, considerando a disponibilidade restrita desse recurso define, segundo o referido autor, o planejamento em recursos hídricos.

Como mecanismo complementar ao planejamento, a gestão de recursos hídricos envolve, na opinião de LIMA (1997), a caracterização ambiental, a

2 BARTH, F. T. et al. (1987). Modelos para gerenciamento de Recursos Hídricos. São Paulo, Nobel/ABRH. Coleção ABRH de Recursos Hídricos, v. 1. 
avaliação dos impactos de atividades já existentes e das que irão se instalar, a investigação da capacidade de assimilação de um corpo receptor, o monitoramento ambiental e a retroalimentação do processo de gestão como um todo, de forma a permitir o aperfeiçoamento do sistema adotado.

Um significado mais amplo é atribuído ao termo 'gestão' quando se trata do meio ambiente como um todo. SOUZA (2000) entende a gestão ambiental como o conjunto de procedimentos que visam a conciliação entre o desenvolvimento e a qualidade ambiental, a partir da observância da capacidade de suporte do meio ambiente e das necessidades identificadas tanto pela sociedade civil quanto pelo governo.

A gestão ambiental, assim entendida, mostra-se totalmente indissociável das políticas ambientais adotadas. É necessário, portanto, que se procure compatibilizar a gestão territorial com a gestão de recursos hídricos (o que faz crer na necessidade de um intercâmbio de informações quando da elaboração de políticas específicas para estes fins, para que os objetivos estabelecidos não se mostrem conflitantes).

Percebe-se a necessidade de mecanismos que propiciem ao Poder Público a execução de uma gestão ambiental apropriada, que aplique os princípios e procure alcançar os objetivos estabelecidos por uma política ambiental. Nesse sentido, convém destacar alguns dos princípios da Política Nacional de Meio Ambiente (Lei $\mathrm{n}^{\circ}$ 6938, de 31 de agosto de 1981), que visa "assegurar, no País, condições ao desenvolvimento sócio-econômico, aos interesses da segurança nacional e à proteção da dignidade da vida humana". Dentre os princípios mencionados, estão relacionados, em seu artigo $2^{\circ}$, a necessidade de "ação governamental na manutenção do equilíbrio ecológico, considerando o meio ambiente como um patrimônio público a ser necessariamente assegurado e protegido, tendo em vista o uso coletivo"; a "racionalização do uso do solo, do subsolo, da água e do ar"; o "planejamento e fiscalização do uso dos recursos ambientais"; a "proteção aos ecossistemas, com a preservação de áreas representativas"; o "controle e zoneamento das atividades potencial ou efetivamente poluidoras"; e a "proteção de áreas ameaçadas de degradação" (incisos I a V, IX).

A Constituição Federal de 1988 estabelece como competência da União e dos Estados legislarem de maneira complementar sobre os recursos hídricos 
superficiais, cabendo aos municípios poucas oportunidades para tanto, excetuandose as peculiaridades apresentadas pelos mesmos (Constituição Federal, artigo 30, incisos I e II). Por outro lado, atribui quase que completamente aos municípios a incumbência de legislar sobre o uso do solo, através de Planos Diretores e políticas de ordenamento territorial. Percebe-se, portanto, em se tratando do Poder Público municipal, que uma das únicas formas de interferência de maneira mais direta na gestão dos recursos hídricos que atravessam seu território é através da gestão territorial.

Ao exercitar essa incumbência, atribuindo metas específicas de uso e ocupação do solo relacionadas à preservação dos recursos hídricos pertencentes ao seu território, o município estaria dando um passo significativo em direção à sustentabilidade ambiental, uma vez que teria em mãos mecanismos apropriados para fazer valer as diretrizes estabelecidas por uma política ambiental (que se supõe comprometida com a preservação de seus recursos naturais e com a compatibilização entre o desenvolvimento econômico e a qualidade ambiental). Para MILARÉ (1999), inclusive, o disciplinamento do uso do solo seria o instrumento ideal para a gestão ambiental municipal, uma vez que abrangeria todas as atividades exercidas no espaço urbano, além de itens de preservação ambiental.

Mais especificamente em relação aos objetivos do presente trabalho, dentre os instrumentos criados pela Política Nacional de Meio Ambiente de modo a tornar possível alcançar seus objetivos destaca-se o zoneamento ambiental (art. $9^{\circ}$, inciso II), instrumento de natureza técnica e política que possibilitaria a otimização do planejamento do uso do espaço e sua conjugação com as políticas públicas.

Decorridos 20 anos de sua criação, existe a necessidade de uma discussão mais ampla e mais aprofundada, de maneira a se chegar a um consenso em relação à sua real finalidade e sobre qual seria a melhor maneira de proceder à sua elaboração. No escopo do presente trabalho, o termo zoneamento ambiental não deve ser entendido apenas como o processo de parcelamento de um determinado espaço com o intuito de estabelecer os usos permitidos em sua ocupação. Envolve, acima de tudo, um comprometimento com uma política de desenvolvimento previamente estabelecida, tendo como função primária fornecer subsídios concretos para a aplicação desta política. 
Sendo assim, os estudos de localização de empreendimentos ${ }^{\text {[ }}$ _ ou atividades econômicas - inseridos no contexto da gestão ambiental, encontrariam nas informações extraídas a partir da elaboração de um zoneamento ambiental a base para a realização de uma análise acerca da viabilidade ambiental da atividade a ser implantada. Além da preocupação em garantir ao empreendedor a existência de condições adequadas em termos de infra-estrutura, mercado consumidor, etc., haveria a procura pela minimização de impactos ambientais negativos, procurandose apontar locais que sejam aptos a suportar a instalação do empreendimento em questão.

\subsection{Viabilidade ambiental - caracterização ambiental e capacidade de suporte do meio}

Para SOUZA (2000), uma das mais importantes etapas da gestão ambiental é cumprida pela caracterização ambiental, responsável pela indicação das vocações e suscetibilidades naturais dos fatores ambientais em conjunto. Observa o autor que a caracterização ambiental proporciona uma visão pró-ativa dos projetos a serem implementados, afinal, tendo em mãos o conhecimento relativo às características do meio ambiente e da atividade a ser implantada, é possível proceder-se a uma análise ambiental de caráter preventivo, que busque determinar a viabilidade ambiental do empreendimento em questão.

De posse dessas informações - a caracterização do meio ambiente e da atividade a ser implantada - é possível a análise de um ponto essencial no estudo de viabilidade ambiental: o binômio tipologia-localização. Dessa forma, ainda de acordo com SOUZA (2000), o planejamento da ocupação do espaço geográfico deve se basear no reconhecimento das potencialidades e fragilidades dos fatores físicos, biológicos e antrópicos que compõem o meio ambiente ante as características e especialidades das atividades a serem acomodadas.

O uso da natureza não pode comprometer as funções ecológicas nem os ciclos existentes. Segundo BEGOSSI (2001), esta questão está intimamente relacionada

\footnotetext{
3 Neste trabalho, adota-se para o termo empreendimento o mesmo significado encontrado em SÁNCHEZ (2001), onde pode ser lido: "O conceito de empreendimento (...) é amplo e inclui não só indústrias manufatureiras mas também os ramos das indústrias extrativas, da construção civil, da produção de energia, do tratamento e disposição de resíduos e, de modo geral, qualquer atividade econômica que produza bens ou matérias-primas em escala industrial (...)"
} 
ao conceito de capacidade de suporte da ecosfera. Sendo assim, as políticas de governo para o desenvolvimento sustentável devem procurar acima de tudo admitir as limitações impostas pelo meio e aceitar a impossibilidade de se obter um crescimento infinito (CAVALCANTI, 2001).

Dependendo do local em que será inserida, uma determinada atividade pode provocar impactos ambientais de diferentes magnitudes (Figura 1). Sendo assim, a observação da capacidade de suporte do meio é condição essencial para a determinação da viabilidade ambiental de uma atividade.

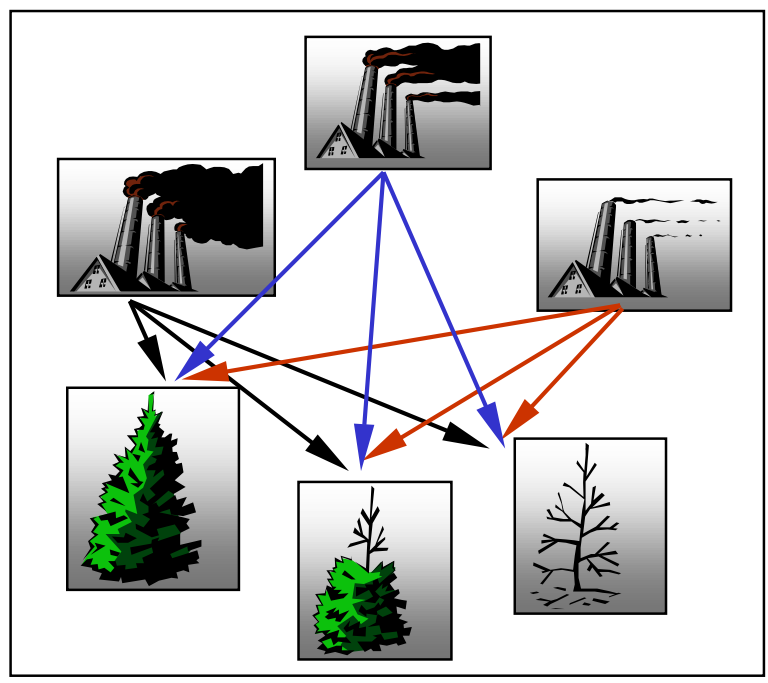

Fonte: MAGNANI (2000)

FIGURA 1: Tipologia x Localização

FILET (1995) define como capacidade de suporte do ambiente a sua habilidade em acomodar, assimilar e incorporar um conjunto de atividades antrópicas sem modificar suas funções naturais em termos de produtividade primária e, ainda assim, proporcionar padrões de vida aceitáveis às populações que habitam esses ambientes.

\subsection{Desenvolvimento Sustentável}

Desenvolvimento sustentável, ou sustentabilidade, tem se tornado um termo comum nos mais diversos campos da atividade humana, com inúmeras interpretações. Pelo seu significado mais simples, de acordo com MERICO (1996), sustentabilidade significa tornar as coisas permanentemente disponíveis ou duráveis. Desenvolvimento sustentável significaria, então, discutir a permanência ou durabilidade da estrutura de funcionamento de todo o processo produtivo. 
Para tanto, segundo o autor, uma das condições fundamentais é a manutenção ou aumento do estoque de capital natural, o que garantiria a possibilidade do meio ambiente continuar desempenhando sua função complementar no sistema econômico. Estas funções incluem o suprimento direto de recursos naturais (matéria-prima) para o processo de produção, o fornecimento de serviços ambientais de suporte à vida (ciclos biogeoquímicos, regulação climática, etc.), a capacidade de assimilação dos resíduos oriundos do processo produtivo e, ainda, como fonte direta de bem-estar através da utilização da natureza para apreciação, contemplação, recreação, etc.

Uma associação comum, embora equivocada, é feita entre desenvolvimento e crescimento econômico, o qual dependeria do aumento no consumo de energia e recursos naturais. Segundo DALY (1991), não se deve confundir crescimento (expansão) com desenvolvimento (realização de um potencial). Esse tipo de equívoco tende a conduzir à insustentabilidade, à depleção dos recursos naturais essenciais, dos quais dependem não somente o próprio crescimento econômico, como também a existência do ser humano e da diversidade biológica. Uma vez que crescimento significa sempre alguma forma de degradação do meio ambiente (GEORGESCU-ROEGEN, 1974, apud CAVALCANTI, 2001), o processo econômico deve se servir da natureza de um modo mais duradouro do que tem mostrado a prática atual

Para BINSWANGER (2001), o conceito de desenvolvimento sustentável deve ser aplicado como uma alternativa ao conceito de crescimento econômico, o qual está associado a crescimento material, quantitativo, da economia. Segundo suas palavras, "isso não quer dizer que, como resultado de um desenvolvimento sustentável, o crescimento econômico deva ser totalmente abandonado" (pág. 41). Segundo o autor, sendo a natureza a base essencial para o pleno desenvolvimento da economia moderna, bem como para as vidas das gerações presentes e futuras, desenvolvimento sustentável significa qualificar o crescimento e reconciliar o desenvolvimento econômico com a necessidade de se preservar o meio ambiente.

Não são mais aceitáveis políticas de desenvolvimento calcadas em argumentos apenas quantitativos, buscando um crescimento econômico que, muitas vezes,

${ }^{4}$ GEORGESCU-ROEGEN, N. (1974). Energy and Economic Myths. In: BURCH, W. \& BORMAN, F. (orgs.). Limits to Growth: the Equilibrium State and Human Society. San Francisco. W. H. Freeman. 
nada tem a ver com desenvolvimento em sentido verdadeiro que resulte numa melhor qualidade de vida para seus agentes. Diversos autores, ao discorrerem sobre a sustentabilidade, pregam a necessidade de uma efetiva modificação no atual modelo de desenvolvimento econômico que possibilite a inclusão, nos processos econômicos, de critérios de caráter ambiental. Sem que isso ocorra, talvez a espécie humana esteja correndo um sério risco de sobrevivência (WCED, 1987; SACHS, 1993; BINSWANGER, 2001; CAVALCANTI, 2001; FLAVIN, 2001). A opinião dos autores converge, ainda, no sentido de que a distribuição dos resultados obtidos pelo desenvolvimento é algo desejado e requerido pela sustentabilidade.

Para ser aplicado com sucesso, afirma ZHOU (1998), o desenvolvimento sustentável deve trazer a perspectiva de que um ambiente saudável é essencial para uma economia próspera. Tal enfoque encara sociedade, economia e meio ambiente como elementos essenciais de um sistema, que se suportam mutuamente. Cada elemento deve ser considerado prioritário na tomada de decisões, fazendo com que as ações sejam baseadas numa estratégia de "antecipar e prevenir". O desenvolvimento sustentável também afirma que os recursos do meio ambiente devem ser examinados tanto pelo seu valor atual quanto futuro, baseado nos princípios de vida dentro de parâmetros ecológicos globais de longo prazo.

\subsection{Gestão ambiental municipal e SIG}

A fim de que uma sociedade possa assegurar para si um meio ambiente saudável e, dessa forma, alcançar a sustentabilidade existe a necessidade de se reconsiderar a gestão ambiental municipal (BUSTRÖM \& KORHONEN, 2001). Dentre os diferentes aspectos da gestão ambiental municipal contemporânea encontra-se a gestão ambiental territorial, relacionada com o planejamento e gerenciamento territoriais, que envolve a gestão dos recursos naturais (água e solo) dentro do território do município.

Há que se considerar a necessidade da existência de uma estrutura adequada que permita aos administradores municipais utilizarem de maneira apropriada os diferentes instrumentos de política ambiental disponíveis, considerando fundamentalmente aspectos relacionados à qualidade das informações com as quais se pretende trabalhar, observando o fato de que as informações produzidas 
são totalmente dependentes da qualidade dos dados de entrada utilizados no processo.

A elaboração de um zoneamento ambiental para o território de um município requer, num primeiro momento, a definição clara do quê se pretende alcançar. Sendo assim, uma questão fundamental a ser ponderada diz respeito à escala de trabalho - que não pode ser muito pequena a ponto de inutilizar as informações produzidas (em função do baixo nível de detalhamento), e nem muito grande a ponto de desvirtuar o zoneamento elaborado (que, num primeiro momento, não deve ter a preocupação de responder a questões pontuais, como qual seria o local ideal para a instalação de um empreendimento, mas sim fornecer indicativos a respeito de regiões ou áreas pertencentes ao território avaliado, com relação à capacidade do meio ambiente em suportar possíveis impactos advindos de eventuais atividades que vierem a se instalar).

RANIERI (2000), em estudo semelhante, apresenta algumas justificativas para a adoção do município como unidade territorial básica para a execução do zoneamento ambiental, ao afirmar que há "uma convergência entre os autores" (por ele estudados) "no sentido da adoção de espaços territoriais não muito extensos para evitar excessivas generalizações e permitir a participação dos atores sociais envolvidos - e com autonomia administrativa, para tornar possível a execução das políticas públicas" (pág. 10). Nesse caso, considera-se que não seria muito eficiente se o zoneamento ambiental fosse elaborado para um território que apresentasse diretrizes administrativas diferentes (como poderia ser o caso de uma bacia hidrográfica que englobasse mais de um município, por exemplo).

A elaboração de um zoneamento ambiental conforme preconizado pelo presente trabalho, por exigir um grande esforço por parte dos envolvidos, prescinde de ferramentas que auxiliem na organização e manipulação da grande quantidade de dados necessária. Sendo assim, não há como imaginar a execução deste estudo sem que se recorra aos recursos oferecidos pelos Sistemas de Informação Geográfica.

O termo Sistemas de Informação Geográfica (SIG) é aplicado para sistemas que realizam o tratamento matemático (através de algoritmos computacionais) de dados geográficos (DAVIS \& FONSECA, 2001). Como característica fundamental, um SIG armazena a geometria e os atributos dos dados que estão 
georreferenciadosǿ isto é, localizados na superfície terrestre e representados numa projeção cartográfica. Ainda, de acordo com EASTMAN (1997), o SIG pode ser entendido como um sistema de banco de dados que tem a capacidade de adquirir, guardar, manipular e mostrar dados referenciados espacialmente, utilizado como ferramenta na busca pela solução de problemas complexos em pesquisa, planejamento e gerenciamento.

Uma das áreas de maior sucesso na aplicação de SIG - segundo GOODCHILD (1993) - tem sido a identificação de problemas ambientais, valendose de suas habilidades em mapeamento, processamento de dados e modelagem.

Dados geográficos possuem características peculiares que fazem com que sua modelagem seja mais complexa do que a de dados convencionais. Modelar os aspectos espaciais é de fundamental importância na criação de um banco de dados geográfico, principalmente porque se está lidando com uma abstração da realidade geográfica onde a visão, ou a percepção, que os usuários têm do mundo real pode variar, dependendo do que eles necessitam representar e do que eles esperam extrair desta representação. (BORGES ${ }^{6}, 1997$ apud DAVIS Jr., 1999).

A possibilidade de combinar informação cartográfica e tabular, bem como embutir conhecimento específico e/ou subjetivo em uma análise, torna um sistema de geoprocessamento uma ferramenta especialmente útil para fins de planejamento. Pode-se entender o planejamento como a aplicação racional do conhecimento do homem ao processo de tomada de decisões para conseguir uma ótima utilização dos recursos, a fim de obter o máximo de benefícios para a coletividade (SANTOS \& NASCIMENTO, 1992).

De acordo com BATTHI \& DENSHAM (1996), o planejamento e o gerenciamento são baseados num processo genérico de resolução de problemas que inicia com a definição e descrição do problema, envolve várias formas de análise (as quais podem incluir simulação e modelagem), passa pela previsão e finalmente alcança a proposição de soluções e alternativas para o problema. Cada etapa deste processo é caracterizada pela tomada de decisões, uma vez que a

\footnotetext{
${ }^{5}$ O termo georreferenciamento, aqui empregado, está grafado de acordo com o encontrado em EASTMAN (1998). Ao que parece, esta é a forma que será adotada pelos autores, embora ainda não se tenha uma consolidação ortográfica para esse termo.

${ }^{6}$ BORGES, K. A. V. (1997). Modelagem de Dados Geográficos: Uma Extensão do Modelo OMT para Aplicações Geográficas, Dissertação de Mestrado, Fundação João Pinheiro, Belo Horizonte.
} 
implementação do plano ou da política escolhidos envolve esta seqüência novamente, numa clara demonstração de sua iteratividade.

No contexto do geoprocessamento, o processo de tomada de decisão envolve vários conceitos, aplicáveis ao estudo que se pretende realizar. Para DAVIS Jr. (1999), uma decisão é uma escolha entre algumas alternativas, que surge após a observação de algum critério. Um critério é alguma base mensurável e avaliável utilizada para uma tomada de decisão, podendo ser um fator ou uma restrição. Um fator realça ou ameniza a aptidão de uma alternativa específica para um propósito em consideração e uma restrição limita as alternativas em consideração. Uma regra de decisão é o procedimento pelo qual critérios são combinados para uma determinada avaliação que visa um objetivo específico.

A abstração de conceitos sobre objetos existentes no mundo real é uma parte importante da criação de sistemas de informação. Além disso, o sucesso da implementação de um sistema de informação é dependente da qualidade da transposição dos objetos do mundo real e suas interações para um banco de dados informatizado (DAVIS Jr., 1999). Novamente se percebe a importância da escala de trabalho e da qualidade dos dados utilizados para a geração de informações.

De acordo com (BUSTRÖM \& KORHONEN, 2001), o maior obstáculo às municipalidades em obter sucesso na gestão ambiental está na ausência de recursos, que pode simplesmente forçar as autoridades a sacrificar suas estratégias de planejamento futuro e atentar apenas aos casos críticos, que exigem uma solução imediata.

O uso da tecnologia de sistemas de informações geográficas vem intensificar e aprimorar os estudos sobre localização de atividades, permitindo aos administradores municipais o direcionamento do crescimento dos municípios para regiões que possuam maior aptidão para receber os empreendimentos, ou seja, apresentam uma maior capacidade de assimilação dos possíveis impactos ambientais advindos dessas atividades, a um custo relativamente pequeno.

Em se tratando da procura pela viabilidade ambiental de empreendimentos, orientados por uma política de desenvolvimento definida, que inclua o meio ambiente como fator a ser considerado no desenvolvimento das atividades 
humanas (conforme preconizado pelo desenvolvimento sustentável), a conjugação dos conceitos até aqui expostos é condição essencial para a obtenção de resultados satisfatórios. É correto afirmar que um comprometimento com a qualidade dos recursos e serviços ambientais demanda, necessariamente, a incorporação de novos valores por parte dos administradores públicos, que deverão permear todo o processo decisório a fim de que se alcance um nível mais elevado e equilibrado de desenvolvimento econômico e social.

O presente trabalho procura discutir os benefícios para a gestão ambiental oriundos da elaboração de um zoneamento ambiental que observe os preceitos estabelecidos pelo desenvolvimento sustentável, conjugando a procura do desenvolvimento econômico à observação das limitações impostas pelo meio ambiente.

Tomando como área de estudo o município de São Carlos (SP), o trabalho apresenta algumas análises elaboradas para o território do município procurandose determinar algumas das aptidões e suscetibilidades apresentadas pelos fatores ambientais em conjunto frente à eventual necessidade de instalação de alguns empreendimentos. Considerando os recursos hídricos como um fator ambiental relevante para a definição do local em que serão instalados, o trabalho apresenta uma proposta de ponderação, a ser inserida nos estudos de zoneamento ambiental, para a determinação da aptidão apresentada pelo território do município referente à instalação da atividade.

O trabalho está estruturado da seguinte forma: no primeiro capítulo introdução - apresentam-se a justificativa e a contextualização da pesquisa; a seguir, são expostos o objetivo geral do trabalho e os objetivos específicos; no terceiro capítulo é apresentada uma revisão bibliográfica a respeito dos temas pertinentes a este trabalho, procurando-se mostrar de que maneira é encarada a elaboração de estudos de zoneamento ambiental no país e se ocorre a inclusão valendo-se do mesmo instrumento - das questões relativas à gestão dos recursos hídricos; em seguida são apresentados os materiais e métodos utilizados no desenvolvimento do estudo de caso para que, no capítulo seguinte, possam ser expostos os resultados e as discussões pertinentes ao tema; por fim, o capítulo contendo as conclusões contempla as conclusões gerais da pesquisa; ao final, é apresentada a bibliografia utilizada para a elaboração da pesquisa. 


\section{OBJETIVOS}

O objetivo geral deste trabalho é apresentar a variável recursos hídricos como fator a ser ponderado na elaboração do zoneamento ambiental para um determinado território, procurando-se definir as aptidões e vulnerabilidades apresentadas pelo território em relação ao desenvolvimento de atividades específicas (considerando, em algum momento, aspectos como demanda, disponibilidade, escassez e qualidade do recurso hídrico), e refletir sobre sua influência na eficácia do processo de gestão ambiental do município de São Carlos $(\mathrm{SP})$.

Para tanto, deverão ser atingidos os seguintes objetivos específicos:

- Elaboração de mapas síntese que provoquem uma reflexão sobre as vulnerabilidades apresentadas pelo território do município com relação à preservação da qualidade dos recursos hídricos, a saber: risco de contaminação de águas subterrâneas, risco de assoreamento de corpos d'água, capacidade de diluição de efluentes e disponibilidade do recurso para abastecimento;

- Elaboração do zoneamento ambiental para o município (ressaltando-se que os resultados obtidos são dependentes da escala das informações utilizadas como entrada), com a confecção de mapas síntese que reflitam as vulnerabilidades e aptidões apresentadas pelo território quanto à instalação de algumas atividades econômicas, considerando-se alguns fatores ambientais tidos como relevantes para a avaliação em questão, além dos recursos hídricos;

- Apresentação de áreas que possam ser consideradas atrativas em se tratando de empreendimentos que sejam compatíveis com as potencialidades ambientais do território. 


\section{ZONEAMENTO ECOLÓGICO-ECONÔMICO (ZEE), ZONEAMENTO AMBIENTAL E OS RECURSOS HÍDRICOS}

Dentre os mecanismos de planejamento à disposição do Poder Público passíveis de serem utilizados no planejamento territorial é possível perceber que, nos anos recentes, o zoneamento ambiental tem se destacado entre as políticas públicas como um instrumento estratégico de planejamento regional, que busca a compatibilização entre o desenvolvimento econômico e a qualidade ambiental. Entretanto, apesar de sua crescente utilização, a prática envolvendo a aplicação deste instrumento é caracterizada pela ausência de uma definição a respeito de suas reais atribuições.

O conceito de zoneamento, no Brasil, está ligado a pelo menos duas tradições (NITSCH, 1998; SAE/PR, 2000; MILLIKAN \& PRETTE, 2000). Uma primeira diz respeito ao planejamento agrícola sob a forma dos zoneamentos agroecológicos ou agrícolas, nos quais se faz um estudo da aptidão dos solos e do clima de uma dada área para diversos tipos de cultura, ou, ao contrário, procura-se identificar as áreas mais adequadas para uma determinada cultura. Trata-se nesse caso de um instrumento técnico, de caráter indicativo, para subsidiar o agricultor em suas decisões de investimento, ou o setor público no que concerne a concessão de créditos para a agricultura (NITSCH, 1998; SAE/PR, 2000).

Uma outra tradição, mais fortalecida pela prática, está ligada à regulação do uso do solo urbano, que se consubstancia, geralmente, em instrumentos legais e normativos - o que fica evidente nas palavras de Paulo Afonso Leme Machado, quando diz que "(...) o zoneamento consiste em dividir o território em parcelas nas quais se autorizam determinadas atividades ou interdita-se, de modo absoluto ou relativo, o exercício de outras atividades". (MACHADO, 1992, p. 96). Para GRINOVER (1989), essa prática de zoneamento, criada pela tecnologia do planejamento territorial desde as primeiras décadas do século $\mathrm{XX}$, expõe suas 
deficiências ao se tentar introduzir a dimensão ambiental no processo de planejamento, uma vez que "não consegue traduzir de forma eficiente a dinâmica das relações de todo tipo e de todos os níveis que se estabelecem no território".

Apesar de ter sido criado há mais de 20 anos, inserido na Política Nacional de Meio Ambiente (Lei $n^{\circ} .6 .938$ de 31/08/81) e, desse modo, constituir um instrumento de gestão ambiental, a regulamentação da legislação sobre o zoneamento ambiental e sua implementação prática (especialmente em termos da estrutura necessária para a sua implementação) ainda não avançaram substancialmente. Talvez devido ao fato de que os primeiros exercícios de zoneamento "de caráter ambiental" (não se deve confundir com o zoneamento ambiental propriamente dito) foram executados com o objetivo de propor um determinado parcelamento do solo do território, a conceituação sobre zoneamento ambiental assumiu, conforme menciona MILLIKAN (1998), um caráter normativo, restritivo, para fins de proteção do meio ambiente.

$\mathrm{Na}$ fronteira Amazônica, por exemplo, no atual momento, o Zoneamento Ecológico-Econômico (ZEE) tem sido apresentado como um instrumento capaz de reverter alguns dos problemas de ocupação desordenada, que tanto despertam a atenção da opinião pública internacional desde os anos 80: desmatamento acelerado, expansão agropecuária em terras de baixa aptidão agrícola, exploração madeireira insustentável, invasões de áreas indígenas e unidades de conservação, entre outros (BECKER \& EGLER, 1996; NITSCH, 1998). No entanto, ao prevalecer o estabelecimento de uma determinada divisão do território em termos das atividades que podem ou não ser desenvolvidas, a elaboração de um zoneamento desse tipo acaba por não cumprir com a verdadeira atribuição de um instrumento de política ambiental, qual seja a provisão de subsídios concretos a serem utilizados pelos administradores na solução de eventuais conflitos que possam surgir.

Sendo assim, há que se deixar claro a distinção existente entre algumas vertentes do zoneamento. Devido ao objetivo do presente trabalho, a discussão se concentra nos processos de zoneamento ecológico-econômico (instrumento amplamente divulgado e, pode-se dizer, utilizado em nosso país) e de zoneamento ambiental (um termo bastante discutido, para o qual não se obteve até o momento 
um consenso quer seja na comunidade científica, quer seja no meio técnicopolítico).

\subsection{O Zoneamento Ecológico-Econômico (ZEE)}

Desde fins da década de oitenta o Governo Brasileiro, reconhecendo os impactos negativos causados pela ocupação desordenada do território nacional, vem promovendo ações para a formulação de uma estratégia que viabilize sua ocupação ordenada e a recuperação de áreas degradadas. Segundo a Secretaria de Estado de Meio Ambiente e Desenvolvimento Sustentável do Rio de Janeiro, tal estratégia requer uma base de conhecimento técnico-científico e de informação acurada sobre a diversidade territorial (NITSCH, 1998, SEMADS, 2000).

A partir de setembro de 1990, quando foi instituída a Comissão Coordenadora do Zoneamento Ecológico-Econômico do Território Nacional - CCZEE (Decreto n. ${ }^{\circ}$ 99.540, de 21/09/90), o governo federal vem desenvolvendo ações para implementar um programa descentralizado de zoneamento ecológico-econômico em todo o território nacional.

Segundo diretrizes da CCZEE, o zoneamento ecológico-econômico do Território Nacional ao nível macrorregional e regional é atribuição do Governo Federal e norteará a elaboração dos planos nacionais e regionais de ordenação do território (SEMADS, 2000). Os Governos Estaduais são convidados a integrar a Comissão, na condição de membros, quando áreas de seus respectivos territórios forem objeto de zoneamento e, através dos estados, prevê-se ainda a participação dos municípios.

O zoneamento ecológico-econômico (ZEE) foi criado para ser um instrumento político e técnico do planejamento com a finalidade de otimizar o uso do espaço e as políticas públicas afins. É um instrumento técnico de informação integrada sobre o território, ao passo em que o classifica segundo suas potencialidades e vulnerabilidades. É um instrumento político de regulação do uso do território, visto que favorece a integração de políticas públicas em uma base geográfica descartando o convencional tratamento setorializado e informatiza o processo de tomada de decisão contribuindo para a negociação entre várias esferas de Governo, e entre estas, o setor privado e a sociedade civil (NITSCH, 1998). 
Para Ab'SABER (1989), o estabelecimento do ZEE deveria equivaler ao estudo de determinação das potencialidades e restrições de todos os subespaços que compõem um certo território, levando-se em conta suas potencialidades econômicas. Isso implicaria em um cruzamento dos conhecimentos sobre os fatores fisiográficos e ecológicos com os fatores da conjuntura econômica, demográfica e social da região.

Seria, de acordo com BECKER \& EGLER (1996), um instrumento ativo para o desenvolvimento sustentável, e não apenas um instrumento corretivo e restritivo como freqüentemente se pensa. E, embora pautado na identificação de zonas homogêneas, na verdade buscaria tirar partido da diversidade territorial, promovendo a compatibilidade sistêmica entre as zonas.

Percebe-se que a conceituação teórica do ZEE o coloca claramente como um instrumento regulador das atividades antrópicas, cuja finalidade seria a de compatibilizar o desenvolvimento econômico de um território com a necessária preservação dos recursos e serviços ambientais. Contudo, ao menos até este momento, as maiores críticas a esse instrumento incidem na falta de clareza quanto aos critérios adotados em sua metodologia - e à falta de consistência científica para sua aplicação (NITSCH, 1998) e quanto à insustentabilidade política encontrada em suas propostas, devido à centralização excessiva de seu processo de elaboração - agravada pela falta de compatibilização entre as diretrizes do zoneamento e as políticas públicas em curso (MILLIKAN, 1998). De forma complementar às críticas anteriores, NITSCH (1998) ainda salienta que o papel do técnico e do cientista é compreender a realidade como ela é ("ser"), e não dizer como as coisas "devem ser". Ou seja, a definição do "dever ser" deve ficar por conta das legítimas instituições democráticas da sociedade.

Uma visão predominante, de acordo com MILLIKAN \& PRETTE (2000), é que a implementação dos programas de zoneamento ecológico-econômico deve basearse na elaboração de um mapa prescritivo, contendo normas sobre atividades permitidas e proibidas entre diferentes "zonas" do território, tipicamente respaldado através de uma lei estadual. Ao longo dos anos, a experiência tem demonstrado as limitações técnicas e políticas desse tipo de zoneamento, principalmente quando 
envolve grandes extensões territoriais. Segundo SCHUBARTðூ(1997) apud NITSCH (1998), “(...) nas escalas de abrangência territorial significativas para o ZEE não há como implementar leis globais de zoneamento, que resultam no fato já observado de que todos ficam contra todos, tornando o zoneamento politicamente insustentável".

HOMMA (2000) salienta que se o produto final de um estudo de ZEE for traduzido em um único mapa onde se alocaria os potenciais e limitações para o desenvolvimento de atividades produtivas, levando-se em conta as condicionantes de solo, clima, tecnologia, aspectos sociais e econômicos, vulnerabilidade, entre outros, este deve ser feito sem pressões políticas. Resulta daí que "a elaboração do estudo de ZEE constitui apenas o passo inicial, em que a maior dificuldade estaria na sua implementação, para não se transformar em meros mapas para enfeitar as paredes das instituições públicas". Por isso, segue o autor, a participação das comunidades nas discussões para a implementação do ZEE é fundamental para garantir um compromisso coletivo da utilização adequada do espaço que se quer proteger ou utilizar.

\subsection{O zoneamento ambiental}

Em 1981, a Lei n. ${ }^{\circ}$ 6.938, que dispõe sobre a Política Nacional do Meio Ambiente enumera, entre os princípios que regem essa política, a racionalização do uso do solo, do subsolo, da água e do ar, o planejamento e fiscalização do uso dos recursos ambientais, a proteção dos ecossistemas, com a preservação de áreas representativas, o controle das atividades potencial ou efetivamente poluidoras, a recuperação de áreas degradadas, e a proteção de áreas ameaçadas de degradação.

Mais adiante (artigo $9^{\circ}$ ), a mesma lei menciona entre seus instrumentos o zoneamento ambiental (inciso II) e a criação de espaços territoriais especialmente protegidos pelo Poder Público Federal, estadual e municipal (inciso VI), tais como áreas de proteção ambiental, de relevante interesse ecológico e reservas extrativistas. Infelizmente, ao mencionar o zoneamento ambiental entre seus

\footnotetext{
7 SCHUBART, H. O. R. (1997). Programa de macrozoneamento ecológico-econômico da SAE conceitos e aplicações. Brasília. Secretaria de Assuntos Estratégicos da Presidência da República.
} 
instrumentos, o texto da lei não avança em sua definição, ficando seu entendimento à mercê da interpretação do texto como um todo.

O termo zoneamento ambiental - como instrumento de planejamento e ordenamento territorial - é utilizado de várias formas, cada qual possuindo um enfoque específico. Segundo de ROO (2000), o instrumento zoneamento ambiental teria como objetivo investigar os conflitos de uso da terra que poderiam surgir devido à aplicação de normas e padrões ambientais e suas conseqüências no planejamento, chamado pelo autor de "Planejamento para a Qualidade Ambiental".

Em sua linha de pesquisa, desenvolvida no Departamento de Planejamento Urbano e Regional da Faculdade de Ciências Espaciais da Universidade de Gröening - Holanda, considera a crescente preocupação a respeito da necessidade em aplicar os princípios do desenvolvimento sustentável em todas as facetas do meio ambiente construído pelo homem, dada a variedade de impactos e atores envolvidos. De acordo com ASHWORT (1995), qualquer expansão no meio ambiente construído (em virtude de alguma atividade antrópica) normalmente conduz a alguns conflitos com o ambiente natural.

No escopo do presente trabalho, o entendimento atribuído ao termo zoneamento ambiental não deve ser restrito ao processo de parcelamento de um determinado espaço com o intuito de estabelecer os usos permitidos em sua ocupação. Segundo MACEDO (1998), a elaboração de um zoneamento ambiental parte de uma questão básica: sua elaboração deve ser feita a partir de uma política de desenvolvimento que se deseja implementar ou manter em um dado território. Se bem utilizado, segue o autor, o zoneamento ambiental constitui-se no melhor instrumento de auxílio aos gestores desta política e a todas as demais partes envolvidas: investidores, empresários, trabalhadores, mercados, Poder Público, etc.

Acima de tudo, enquanto instrumento de uma política ambiental, sua utilização requer a existência de uma ligação com outros instrumentos - dentre os instrumentos criados pela Lei 6938 e que atuariam em conjunto com o zoneamento ambiental, encontram-se, entre outros, a Avaliação de Impactos Ambientais, a criação de espaços territoriais especialmente protegidos e o estabelecimento de normas e padrões a serem observados - de modo a aumentar a eficácia na utilização dos mesmos. 
Para SOUZA (2000):

"a existência do zoneamento ambiental de forma consolidada daria um dinamismo muito maior à aplicação de diversos instrumentos e mecanismos da política ambiental, na medida em que forneceria a base, o conhecimento global da área de estudo de forma sistemática, o que faria com que os estudos de impactos ambientais, por exemplo, obtivessem uma outra dinâmica nas tomadas de decisão no que se refere à viabilidade ambiental do empreendimento" (pág. 39).

Nesse sentido, complementa o autor, o zoneamento se associa à caracterização ambiental, possibilitando a determinação das vocações e suscetibilidades do meio ambiente, considerando fatores ambientais específicos.

Sendo a função básica do zoneamento ambiental o fornecimento de informações que permitam a avaliação da situação existente em um determinado território, em termos das restrições e limitações impostas pelos fatores ambientais no que diz respeito ao desenvolvimento de atividades, percebe-se claramente o caráter preventivo associado à correta utilização deste instrumento. Ao possibilitar a visualização da distribuição das áreas com maior ou menor aptidão (ou potencial) para a implantação de determinadas atividades, o zoneamento ambiental surge como um instrumento essencial para a definição das estratégias de ocupação do território levando-se em consideração as limitações impostas pelo meio ambiente.

O que se entende no presente trabalho como zoneamento ambiental passa, inicialmente, pelo processo de determinação das vulnerabilidades e aptidões do território, sem que seja preestabelecido qualquer tipo de uso para o mesmo. De acordo com MACEDO (2001), antes disso é imprescindível efetuar o levantamento, não de uma, mas de todas as vocações do território analisado, para depois, num segundo momento, ordenar-se as atividades que mais se adaptam às comunidades que podem ser beneficiadas, às determinações das culturas locais diretamente envolvidas, às expectativas dos mercados disponíveis para os produtos/serviços a serem oferecidos e que apresentam compatibilidade com o espaço biofísico em que irão ser realizadas.

Ressaltando um aspecto que sem dúvida traria a necessária legitimidade ao processo, a elaboração de um zoneamento ambiental deveria culminar com uma 
ampla discussão envolvendo o Poder Público e a sociedade, com a finalidade de encontrar o melhor caminho para a implementação da referida política de desenvolvimento, que determinará a destinação a ser dada para o território em questão. O zoneamento ambiental deve ser visto, portanto, como um instrumento cuja finalidade é auxiliar a formulação de políticas e estratégias de desenvolvimento a serem implementadas em um determinado território.

\subsection{Aplicações do zoneamento ambiental}

Ao longo da pesquisa efetuada sobre o tema, foi possível perceber de maneira bastante clara que o termo zoneamento está fortemente associado ao processo de parcelamento do solo e ao estabelecimento de usos específicos, especialmente aplicados ao meio urbano, através de leis e decretos. Isso explica em parte a relutância dos diversos atores envolvidos com o planejamento do uso do solo (órgãos gestores, empresários, cidadãos em geral) em aceitar propostas mais concretas relativas ao zoneamento, por entenderem que a sua possível aplicação acarretaria em uma série de restrições e complicações para todas as partes.

Alguns autores entendem, inclusive, que a elaboração do zoneamento ambiental seria desnecessário, uma vez que já existiriam mecanismos capazes de controlar e ordenar a ocupação do território. Na opinião de CHARLES (1998), o zoneamento seria um instrumento de comando e controle facilmente substituível por mecanismos baseados na estrita aplicação dos direitos de propriedade, incentivos de mercado e descentralização na tomada de decisões.

O autor defende a idéia de que a aplicação do zoneamento com a finalidade de preservação dos recursos naturais (incluindo-se a proteção de florestas, preservação de áreas cultiváveis) seria desnecessária frente aos mecanismos de mercado e inovações tecnológicas que teriam condições de suprir uma eventual queda na provisão de serviços ambientais (produção de alimentos, apenas para citar um argumento utilizado). Mas, mesmo assim, reconhece que a prevenção e/ou mitigação dos efeitos negativos advindos do uso da terra, como a poluição e outras perturbações é uma razão legítima para a regulação do uso de terras privadas.

No escopo do presente trabalho, o interesse maior deixa de ser a aplicação do instrumento zoneamento enquanto mecanismo controlador do uso do solo para recair na sua utilização como provedor de subsídios concretos para a formulação 
de políticas de desenvolvimento que tenham como objetivo a contemplação das premissas do desenvolvimento sustentável, ou seja, a determinação da viabilidade ambiental dos empreendimentos juntamente com sua viabilidade econômica.

É sob esse aspecto que se enquadra o instrumento zoneamento ambiental. Ainda que seja feita uma distinção entre as diferentes vertentes do zoneamento, não existe uma definição consolidada para o termo zoneamento ambiental, quer seja no meio científico, quer seja no meio técnico. A seguir, são apresentados algumas aplicações encontradas para o instrumento zoneamento ambiental.

O Brasil experimenta uma tentativa de consolidação desse instrumento, criado pela Política Nacional de Meio Ambiente de modo a auxiliar sua implementação, por meio da elaboração de zoneamentos ecológico-econômico (ZEE), utilizado em larga escala pelos Estados a partir do final da década de 80, com uma acentuada predominância durante a segunda metade da década de 90, sobretudo nos Estados amazônicos, incentivado - de acordo com MILLIKAN \& PRETTE (2000) - por programas de financiamento promovidos por fontes externas, especialmente o Subprograma de Políticas de Recursos Naturais (SPRN) do Programa Piloto para a Proteção das Florestas Tropicais no Brasil (PP/G-7).

Essa tentativa, incontestavelmente válida - por se tratar da primeira vez que instrumentos de gestão e planejamento ambientais foram utilizados de maneira sistematizada com o intuito de preservação dos fatores ambientais, acabou por se mostrar - infelizmente - apenas como um recurso para validar o processo de desenvolvimento vigente até então.

Os exemplos de ZEEs executados pelos estados amazônicos mostram o quanto pode ser distorcido este instrumento e arriscado executá-lo, sem que sejam definidos "as diretrizes nacionais, os parâmetros de um zoneamento macroeconômico, tantas vezes prometido quanto adiado pelo governo federal, nos últimos doze anos" (JOHN, 2001). Ao avaliar a metodologia utilizada até aquele momento nos ZEE elaborados para os estados amazônicos, NITSCH (1998) se refere a esse tipo de ZEE como sendo um "exercício caro, cientificamente obscuro e ecologicamente contraproducente", ao destacar vários pontos falhos na metodologia utilizada, principalmente no que se refere à clareza dos conceitos aplicados e à falta de viabilidade política do zoneamento proposto. 
O Zoneamento Ecológico-Econômico elaborado para Rondônia, por exemplo, dividiu o estado em 3 regiões distintas: áreas de uso agrícola (zona 1), onde o desmatamento pode chegar a $80 \%$ de cada propriedade; áreas mistas (zona 2) e áreas de preservação (zona 3), que correspondem aos parques, estações ecológicas, reservas biológicas, reservas extrativistas, reservas de desenvolvimento sustentável e terras indígenas, sendo os três últimos ocupados por comunidades tradicionais, com exploração de produtos florestais (RONDÔNIA (ESTADO), 2001).

A zona 1 corresponde à metade do estado, sendo que em $26 \%$ do território está previsto o desmatamento até $80 \%$ e em $13 \%$ o desmatamento até $60 \%$, ambos ilegais perante a lei federal vigente (Código Florestal, Lei n 4771/65 e alterações). A zona 3, de preservação, corresponde a $36 \%$ e o restante, 14\%, é zona 2. Segundo os textos disponibilizados pela Secretaria de Meio Ambiente de Rondônia (RONDÔNIA (ESTADO), 2001), os critérios que nortearam a divisão das zonas foram "situações reais", ou seja, o que já está desmatado entrou na zona agropecuária e o que ainda está em pé entrou na zona de preservação. A justificativa, segundo JOHN (2001), seria garantir a sobrevivência econômica de 100 mil famílias, que vivem de agropecuária em Rondônia.

Percebe-se claramente que critérios técnicos para a divisão das zonas, tais como aptidão dos solos, tipo de clima, sensibilidade à erosão, proteção a nascentes, proteção das espécies animais e vegetais mais raras ou ameaçadas, tipo de relevo, regime fluvial, ocorrência/abundância de espécies comerciais, etc., foram relegados a um segundo plano, "como se essas 100 mil famílias pudessem viver de costas para estes fatores e não dependessem da água, da fertilidade da terra e do equilíbrio específico de cada ecossistema, para alcançar o mencionado sucesso econômico" (JOHN, 2001).

MERCADANTE (2001), ao comentar sobre o mesmo ZEE elaborado, afirma que talvez fosse possível obter-se praticamente o mesmo mapa final apenas observando-se as imagens de satélite, que obviamente retratam a situação do território imageado apenas naquele momento em que as cenas foram adquiridas. Isso se deve, segundo o autor, à adoção do "custo de oportunidade" como fator primordial de ponderação, um fator que se refere ao valor que seria necessário despender para se ocupar um determinado território. Dessa forma, os locais que já se encontravam com um grau de ocupação relativamente acentuada - o que, para 
a região amazônica, significa dizer que já estão "cortados" por uma estrada - foram decretados como zonas de ocupação intensiva. De maneira similar, as áreas em que a floresta ainda mantinha suas características próximas das originais - sem estradas de acesso e, portanto, representam um alto custo de oportunidade para serem exploradas - foram declaradas como zonas de uso restrito.

Ao mesmo tempo em que são elaborados estudos de ZEE como o de Rondônia, existem exemplos que indicam que mesmo esse tipo de ZEE elaborado até então mostra sinais de que uma nova percepção em relação à metodologia de execução está se formando. O ZEE elaborado para o Estado do Acre, por exemplo, em sua primeira aproximação já dedica um espaço considerável à participação popular, tendo inclusive levado em consideração o "Zoneamento que a História realizou", nas palavras do então governador do Estado (ACRE, 2000). Um outro aspecto positivo com relação a esse ZEE elaborado é o fato de atribuir como objetivo central desse instrumento "subsidiar processos de planejamento participativo, visando a implementação de políticas públicas voltadas para um novo estilo de planejamento regional e ordenamento territorial, norteado por princípios de Desenvolvimento Sustentável" (ACRE, 2000). Ou seja, subsídios para a tomada de decisões sobre o desenvolvimento do Estado, contribuindo para o planejamento de ações governamentais e políticas públicas estratégicas.

Atualmente, encontra-se em andamento o programa de elaboração do ZEE para todo o território nacional, após a instalação, pelo Ministério do Meio Ambiente, do Consórcio ZEE-Brasil. Composto por diversas entidades, como IBGE, IPEA, CPRM, INPE, EMBRAPA, todas com experiência em elaboração de zoneamentos, alguns específicos para certas áreas, este consórcio recebeu como primeira missão a ser executada a definição de uma metodologia unificada para a elaboração do ZEE no Brasil. Segundo as palavras do então ministro do Meio Ambiente, José Sarney Filho, “...encontrando a metodologia do ZEE brasileiro, sua implementação será muito mais rápida" (conforme texto do próprio MMA, em fevereiro de 2002).

Em alguns casos de aplicação encontrados, o termo zoneamento ambiental não é aplicado de maneira explícita, porém uma análise sobre metodologia utilizada permite uma identificação direta com a conceituação a ser seguida neste trabalho. É o caso, dentre tantos, de KRONEMBERGER \& CARVALHO (1999), que apresentam uma proposta de aplicação de metodologia de apoio à gestão 
ambiental, considerando as potencialidades e vulnerabilidades naturais do território e as características intrínsecas à sociedade local, para o município de Angra dos Reis (RJ). As autoras procuram explorar cenários de mudanças no uso do solo a partir de decisões ambientais simuladas e avaliar as suas conseqüências, com o intuito de contribuir para facilitar a ocupação dos diversos espaços municipais por atividades econômicas compatíveis com suas potencialidades e vulnerabilidades.

\subsection{O zoneamento ambiental e os recursos hídricos}

Mais especificamente em relação aos objetivos deste trabalho, foi possível perceber que a inexistência de uma metodologia consolidada e, antes, de uma definição mais precisa a respeito dos objetivos do instrumento zoneamento ambiental acaba por provocar algumas distorções em relação à sua utilização. Isso explica, em parte, o fato da questão da inserção dos recursos hídricos como fator a ser ponderado no momento da elaboração de um zoneamento ambiental surgir como um elemento secundário, que devesse ser considerado apenas em casos mais específicos, numa etapa posterior.

Em se tratando da procura do local para o assentamento de atividades econômicas pode-se dizer que esta vem sendo definida, via de regra, avaliando-se fundamentalmente os parâmetros que possuem maior relevância para os empresários na escolha de sua área, que minimizem os custos de instalação, produção e distribuição (AYRES, 1991). Fatores como mercado consumidor, custos de transportes e localização da matéria-prima se comportam como variáveis matemáticas na definição do melhor local para a instalação, tornando este ou aquele local mais ou menos atrativo, de acordo com os interesses do empreendedor.

De acordo com o processo vigente até então, percebe-se que apenas muito raramente, os fatores ambientais são considerados como relevantes dentro do processo de decisão - a menos que exista alguma implicação de ordem legal ou econômica, os recursos naturais são vistos como meros coadjuvantes (até mesmo como empecilho) para o desenvolvimento de um território, e não poderia ser diferente em se tratando dos recursos hídricos.

Segundo JOURAVLEV (2001), em muitos locais se deseja manejar o meio ambiente de forma abrangente, porém freqüentemente se esquece de que a gestão dos recursos hídricos deve ocupar um lugar de destaque na gestão ambiental. Não 
se avançou o suficiente na organização e operação de entidades de gestão que garantam o uso múltiplo da água, existindo uma tendência em reduzir a importância relativa dos recursos hídricos no contexto da preocupação pelo meio ambiente como um todo.

Um dos aspectos mais importantes, que justificam a necessidade de reformas no que diz respeito à gestão de recursos hídricos, é a necessidade de melhorar a gestão e o aproveitamento da água para enfrentar a crescente necessidade por seu uso múltiplo, em particular devido ao incremento da demanda pela água em grandes concentrações urbanas, na indústria, na agricultura - irrigação - e para geração de energia. Ressaltando a relevância da questão, FLAVIN (2001) afirma que "a combinação do crescimento populacional com o aumento do consumo deverá provocar um salto no número de pessoas que vivem em países com déficit hídrico, de 505 milhões para mais de 2,4 bilhões, nos próximos 25 anos".

À medida em que a água disponível está cada vez mais escassa - tanto em quantidade quanto em qualidade e tempo de ocorrência - em relação às demandas crescentes da sociedade, a atenção dos governos se desloca gradualmente do interesse em expandir e subsidiar o desenvolvimento do setor - o que quer dizer a gestão da oferta - para a geração de ingressos e o restabelecimento da água disponível - a gestão da demanda (JOURAVLEV, 2001). De acordo com ARAÚJO et al (1999), o estabelecimento de uma distinta ligação entre os diversos usos da água e seus requisitos de qualidade é fundamental. Determinados usos da água são considerados nobres, exigindo, portanto, um rigoroso controle da qualidade, enquanto outros são mais permissivos e não estão vinculados a rígidos critérios de qualidade.

Dentre as diversas formas de uso e ocupação do solo por empreendimentos, algumas delas possuem notório potencial gerador de impactos sobre os recursos hídricos superficiais. CANTER (1996) afirma que muitos tipos de empreendimentos, planos, programas ou políticas apresentam impactos para as águas superficiais. Os efeitos podem ser representados por alterações quanti ou qualitativas que, por sua vez, podem trazer implicações para a fauna e flora aquáticas. Exemplos de projetos potencialmente impactantes para as águas superficiais incluem:

- indústrias descarregando efluentes provenientes de operações rotineiras ou de acidentes e derramamentos; 
- resíduos provenientes de estações de tratamento de água e esgoto, após tratamento primário, secundário ou terciário;

- projetos envolvendo aterros ao longo de rios, estuários e áreas costeiras;

- mineração superficial, com resultante alteração na hidrologia e fontes não pontuais de poluição;

- construção de represas para abastecimento, regulação de vazão ou geração de energia;

- canalização de rios para melhorias no escoamento;

- desmatamento e desenvolvimento agrícola resultando em poluição difusa carregada com nutrientes e pesticidas, e projetos de irrigação;

- resíduos perigosos provenientes do comércio, aterros sanitários, industriais, com poluição difusa;

- loteamentos urbanos e rurais.

Ainda sobre os impactos nos recursos hídricos relacionados ao uso do solo, LIMA-E-SILVA et al. (2000) ressaltam que os corpos d'água sofrem toda a sorte de danos, resultantes da exploração dos recursos naturais e da simples ocupação humana em determinadas áreas. O ciclo hidrológico é alterado pelo uso inadequado da terra, como desmatamento e agricultura intensiva, ou sobre a área urbana, que provoca um aumento no escoamento superficial em detrimento da infiltração, dando início a processos erosivos intensos. Para reforçar estas colocações, BASTOS \& FREITAS (2000) afirmam que em áreas de agricultura intensiva ou em processo de obras de urbanização, a carga de sedimentos que alcança os rios sofre um aumento considerável. Estes fatos poderiam ser considerados, de certa forma, como similares aos ocorridos nos períodos de erosão natural, não fosse o fato da ação do homem abreviar o tempo e intensificar o efeito destas mudanças.

Durante o levantamento bibliográfico efetuado para a obtenção de informações relativas a aplicações de zoneamentos ambientais, foi possível perceber a inexistência de um número expressivo de trabalhos que incluíssem os recursos hídricos como fator a ser ponderado no momento da elaboração do zoneamento ambiental e que sejam compatíveis com a proposta do presente trabalho. 
PARIZZI et al (2001) apresentam um zoneamento geotécnico que leva em consideração aspectos qualitativos relativos aos recursos hídricos, fundamentalmente procurando estabelecer a suscetibilidade de contaminação de águas subterrâneas. A partir da elaboração deste zoneamento, os autores puderam detectar alguns conflitos de ocupação em ambientes frágeis e efetuaram uma proposta de uso do solo apropriado às condições locais.

Uma interpretação para o termo zoneamento ambiental que se aproxima bastante dos objetivos do presente trabalho é encontrada em Di BONA (2000). autor se refere a uma nova metodologia de planejamento do uso do solo, desenvolvida pela Charles River Watershed Association (algo como um comitê de bacia hidrográfica, sediada em Auburndale, Massachusetts), que busca integrar aos Planos Diretores tradicionais a preocupação com a sustentabilidade dos recursos hídricos. Este "zoneamento ambiental" procura acima de tudo a observação do ciclo hidrológico, reconhecendo o recurso hídrico como um fator limitante ao crescimento. O processo se inicia com a identificação de áreas aptas para a disposição de efluentes, recarga e das regiões importantes para a proteção da qualidade das águas e, através de um processo bastante participativo (prevê a participação da comunidade envolvida por meio de consultas e reuniões), procura apresentar sugestões que complementariam as leis de zoneamento locais.

Como resultado, ocorre uma melhoria em termos qualitativos e quantitativos do recurso hídrico, através de um zoneamento legalmente amparado, elaborado com base em informações científicas e legitimado pela extensa participação pública. Para Di BONA (2000), este tipo de zoneamento permite às cidades um controle sobre o seu próprio destino, direcionando o desenvolvimento às áreas realmente aptas a suportá-lo.

Com relação à localização mais adequada para a implantação de uma atividade, qualquer que seja, embora sendo de difícil determinação, pode-se afirmar que a municipalidade, mas também e principalmente o Estado, devem assegurar que a tecnologia e os processos que serão utilizados sejam adequados para minimizar impactos e riscos ambientais (SÃO PAULO (ESTADO), 1991). Percebese que a existência de estudos de zoneamento ambiental para um determinado território, comprometidos com a manutenção da qualidade ambiental, poderia 
facilitar bastante o papel dos administradores e dos responsáveis pelo licenciamento das referidas atividades.

Em outras palavras, ao conciliarem-se os fatores desejados pelos empreendedores, de natureza técnica e econômica, com alguns fatores limitantes ou potencializadores ditados pelo meio ambiente, observadas ainda as normas legais $^{8}$ que regem determinadas atividades, seria dado um grande passo rumo à sustentabilidade e à conseqüente compatibilização entre o desenvolvimento econômico e a qualidade ambiental.

\footnotetext{
${ }^{8}$ Com relação ao disciplinamento do uso dos recursos hídricos, objeto maior do presente trabalho, no Estado de São Paulo a autorização de uso referente ao recurso é estabelecida mediante um mecanismo de outorga. A Portaria DAEE 717/96, de 12 de dezembro de 1996, estabelece, dentre outras coisas, que "a implantação de empreendimento, que demande a utilização de recursos hídricos superficiais ou subterrâneos, dependerá de manifestação prévia do DAEE, por meio de uma autorização", sem no entanto, que isso signifique o direito de uso (artigo $2^{\circ}$ ) Em outro artigo $\left(5^{\circ}\right)$, determina que "dependerão de outorga, passada pelo DAEE, (...) os lançamentos de efluentes nos corpos d'água...”. Existem ainda diversos dispositivos legais específicos para o Estado de São Paulo, que regem o uso dos recursos hídricos, como por exemplo a Lei de Preservação de Mananciais, Lei n. ${ }^{\circ}$ 966/97. Em nível nacional, destaca-se a Política Nacional de Recursos Hídricos, Lei $n^{\circ}$ 9.433/97.
} 


\section{MATERIAIS E MÉTODOS}

\subsection{Caracterização da área de estudo}

A seguir, é apresentada uma breve caracterização do município de São Carlos, escolhido para a realização do estudo de caso. A figura 2 mostra a localização do município em relação ao Estado de São Paulo.

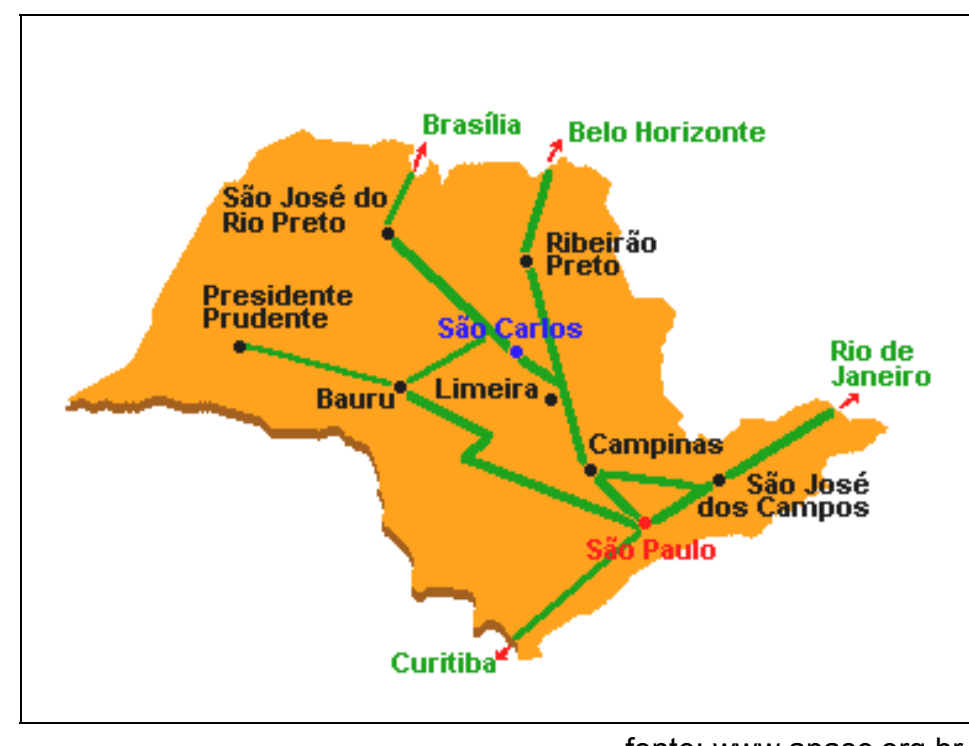

fonte: www.apasc.org.br

FIGURA 2: Localização do município de São Carlos em relação ao Estado de São Paulo

O município de São Carlos está situado na região central do estado de São Paulo, na província geomorfológica das Cuestas Basálticas (PONÇANO et al., 1981), onde havia o predomínio da vegetação de Cerrado e da Floresta Estacional Semidecídua (remanescentes de Mata Atlântica). Atualmente, os remanescentes destes ecossistemas situados na região de São Carlos sofrem grande pressão devido à expansão da atividade agrícola (principalmente cana-de-açúcar e laranja), mineração e silvicultura (reflorestamento de pinus e eucaliptus para as indústrias de lápis, papel e celulose) (ESPÍNDOLA et al., 2000). 
A fauna da região é composta por animais de porte variado, alguns inclusive em vias de extinção: tamanduá, tatu, ema, seriema, cascavel, lobo-guará, cervo, carcará e tucano, dentre outros, ainda podem ser observados nas áreas remanescentes de Cerrado, assim como, nas matas, algumas espécies de mico, capivara, anta, jararaca, etc. (SÉ, 1992)

O clima da região é o Tropical de Altitude, com verões chuvosos e invernos secos, caracterizando seis meses quentes e úmidos e seis meses frios e secos. As temperaturas médias são: máxima em torno de $26,9^{\circ}$ e mínima, $16,2^{\circ} \mathrm{C}$. As variações médias entre os períodos da manhã e da noite são de $5^{\circ} \mathrm{C}$. A precipitação pluviométrica está em torno de 1.500 mm anuais (SÉ, 1992).

O município dista aproximadamente $240 \mathrm{~km}$ da cidade de São Paulo, fazendo limite com os seguintes municípios: ao Norte, Rincão, Luiz Antônio e Santa Lúcia; ao Sul, Ribeirão Bonito, Brotas e Itirapina; a Oeste, Ibaté, Araraquara e Américo Brasiliense, e a Leste, Descalvado e Analândia. O município de São Carlos possui, de acordo com os arquivos gerados, uma área tota ${ }^{9}$ de $1.137,66 \mathrm{~km}^{2}$, sendo que a área urbana cobre cerca de $40 \mathrm{~km}^{2}$.

O território do município está situado em duas Unidades de Gerenciamento de Recursos Hídricos - UGRHI, observando-se a divisão efetuada pela Lei Estadual n. ${ }^{\circ}$ 7.633/91 para o Estado de São Paulo (de acordo com IPT (2000), 39.35\% do território está situado na UGRHI 13 - Tietê-Jacaré, e 60.65\% na UGRHI 9 - MogiGuaçu). Toda a área urbana, excetuando-se o condomínio Samambaia, os distritos de Água Vermelha e Santa Eudóxia, está situada na Bacia do Tietê-Jacaré (UGRHI 13), mais especificamente na bacia do Alto Jacaré-Guaçu, sendo que a maior parte desta é drenada pela bacia do rio do Monjolinho, afluente do rio Jacaré-Guaçu (que perfaz o limite ao Sul do município), e que por sua vez é afluente do rio Tietê. A porção Norte do território do município é limitada pelo rio Mogi-Guaçu.

A figura 3, a seguir, ilustra a situação exposta nos parágrafos anteriores:

\footnotetext{
${ }^{9}$ Esse dado difere ligeiramente do obtido junto ao IBGE, através do site Cidades (www.ibge.gov.br), que é de $1141 \mathrm{~km}^{2}$, provavelmente devido aos erros de digitalização da divisa estabelecida pelo rio Mogi-Guaçu. Para efeito comparativo, note que IPT (2000) menciona outro valor para a área total do município $\left(1145,46 \mathrm{~km}^{2}\right)$.
} 

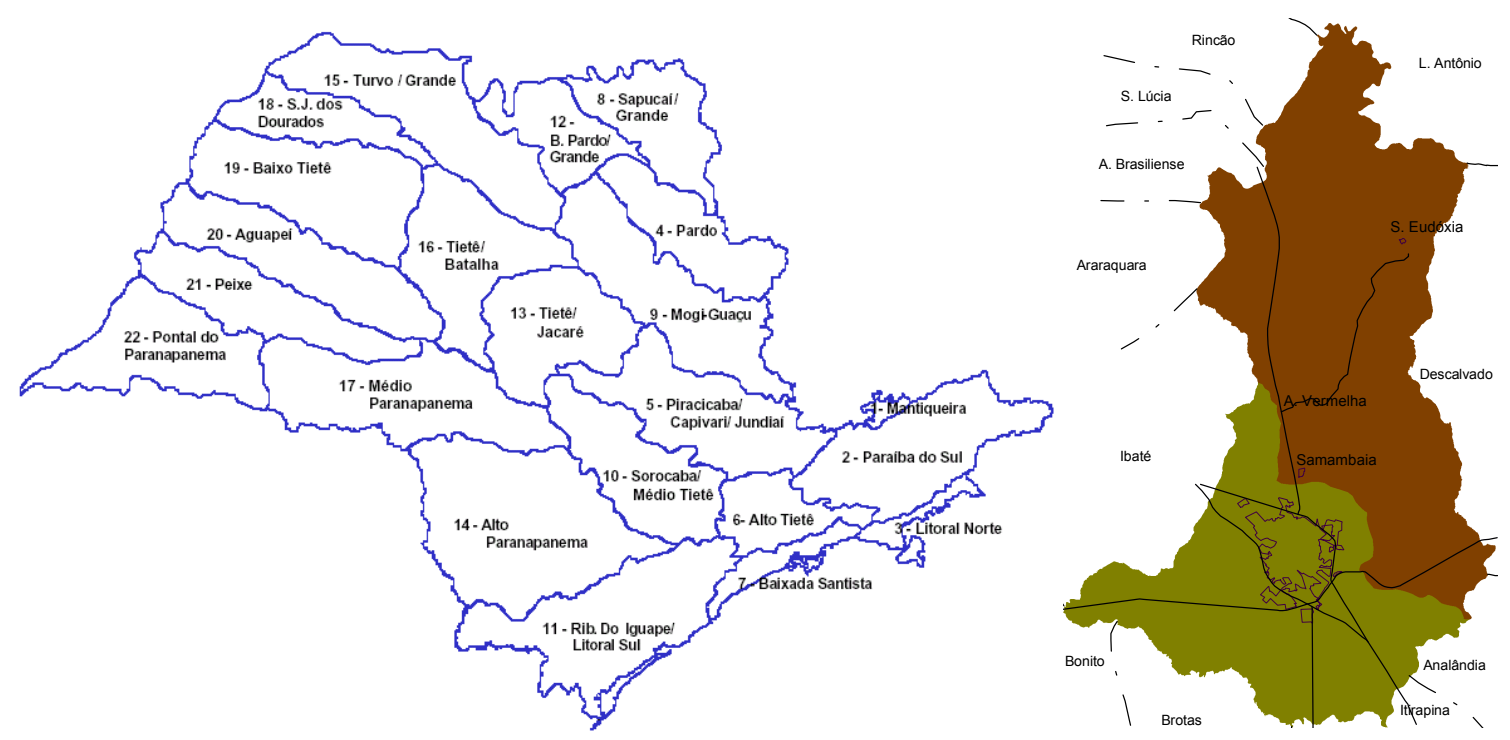

FIGURA 3: Unidades de Gerenciamento de Recursos Hídricos às quais pertence o município de São Carlos

Com uma população próxima dos 200.000 habitantes (192.998 habitantes, de acordo com o censo 2000, divulgado pelo IBGE ${ }^{10}$, uma receita orçamentária da ordem de R\$ 60 milhões (para o ano de 1998) e uma renda per capita estimada em R\$ 7 mil anuais, São Carlos apresenta uma economia bastante diversificada, com destaque para as indústrias de cerâmica, de aparelhos computadorizados, metalúrgica, de transformação de plásticos, têxtil, de motores e compressores, bem como a produção de leite e derivados, a cana-de-açúcar e a laranja (IPT, 2000). Dados do IBGE apontam que a área ocupada por estabelecimentos agropecuários correspondia, em 1995 $\frac{11}{1}$, a 88138 ha, da qual a área antropizada por estes estabelecimentos correspondia a cerca de $54 \%$ do território do município, ou cerca de 61.600 ha.

\subsection{Aspectos metodológicos}

Dado o objetivo fundamental deste trabalho, qual seja o de verificar a possibilidade de inserir uma ponderação referente aos recursos hídricos, considerando as restrições e potencialidades relacionadas às suas características, em um processo de elaboração de um estudo de zoneamento ambiental, foi dada

\footnotetext{
${ }^{10}$ Estes dados, bem como os seguintes, foram obtidos juntamente ao Instituto Brasileiro de Geografia e Estatística (IBGE), www.ibge.gov.br, e ao Programa Educar, do CNPq, http://educar.sc.usp.br/biologia, em 27/12/2001.

${ }^{11}$ Informação obtida junto ao site Cidades@, do IBGE, www.ibge.gov.br.
} 
ênfase àquelas atividades que tivessem o recurso hídrico como um fator ambiental importante para o seu desenvolvimento, ou seja, que fossem usuárias do mesmo. Além disso, efetuou-se uma série de avaliações que permitiram estabelecer um panorama acerca das vulnerabilidades apresentadas pelo meio no que se refere à qualidade dos recursos hídricos. Sendo assim, o presente trabalho apresenta algumas avaliações para o território do município envolvendo os temas: suscetibilidade à erosão, determinação do risco de contaminação das águas subsuperficiais, risco de assoreamento dos corpos d'água superficiais, além da determinação dos potenciais para as atividades: instalação de indústria (usuária de recurso hídrico), captação de água superficial para abastecimento público e instalação de Estação de Tratamento de Esgotos (ETE).

Levando-se em consideração a procura pela determinação da aptidão apresentada pelo território frente à implantação das atividades elencadas o estudo de caso ora apresentado foi efetuado, observando-se as etapas apresentadas na figura 4, conforme segue:

- Criação da base de dados digital georreferenciada:

- levantamento e aquisição das informações existentes que fossem relevantes para o estudo em questão;

- armazenamento das informações em formato digital através da transformação dos mapas em papel para o formato digital, pelo processo de digitalização;

- edição dos arquivos para posterior manipulação.

- Definição das atividades a serem consideradas, cujas características fossem adequadas para ilustrar a avaliação apresentada;

- Levantamento bibliográfico sobre as ponderações a serem efetuadas para os diferentes fatores ambientais, de acordo com a atividade considerada;

- Síntese das informações levantadas - manipulação do banco de dados digital, em ambiente de Sistema de Informação Geográfica, de modo a permitir a sobreposição das informações;

- Aplicação para o território do município, para cada atividade considerada. 


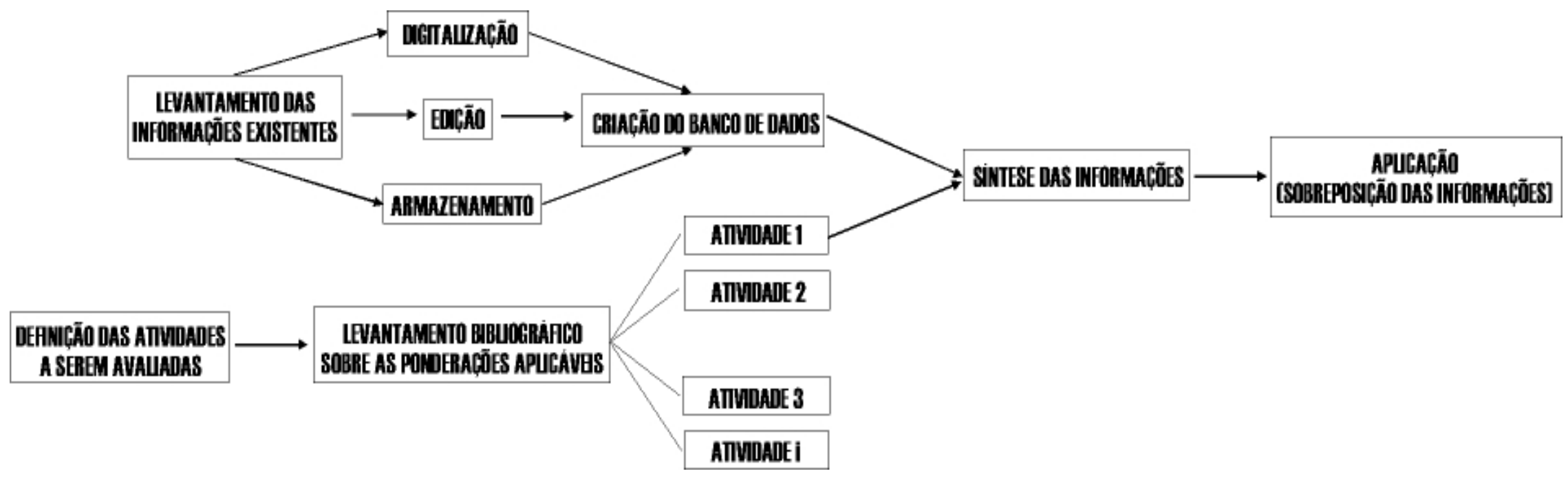

FIGURA 4: esquema de execução do trabalho 


\subsection{Materiais}

Para a geração da base de dados digitais, utilizou-se o software CartaLinx, versão 1.2, para a geração de arquivos vetoriais, e o software Idrisi for Windows, versão 132.11, para o tratamento e manipulação dos dados, ambos desenvolvidos pela Graduate School of Geography, da Clark University, Massachusetts.

As informações relativas aos fatores ambientais considerados foram extraídas de mapeamentos executados e publicados por diversas fontes, a saber:

- Topografia, hidrografia e infra-estrutura (rodovias, ferrovias e rede de alta tensão): extraídos do levantamento topográfico efetuado pelo IBGE e publicado em 1971, em escala 1:50.000, utilizando-se as folhas Corumbataí, Descalvado, Ibaté, Porto Pulador, Ribeirão Bonito e São Carlos;

- Pedologia: Levantamento Pedológico Semidetalhado do Estado de São Paulo, realizado pelo Instituto Agronômico de Campinas - IAC, publicado em 1981, em escala 1:100.000, utilizando-se as quadrículas São Carlos, Descalvado e Brotas;

- Geologia: Mapa Geológico do Estado de São Paulo, efetuado pelo DAEE, publicado em 1982, em escala 1:250.000, utilizando-se parte das folhas Bauru, Campinas e Ribeirão Preto;

- Vegetação natural: mapa contendo os fragmentos de vegetação natural utilizado pelo DEPRN, plotado em mapa escala 1:50.000, e complementado por interpretação visual de imagem de satélite, sensor TM-LANDSAT, órbita-ponto 220_75, obtida em 28/09/1997.

- Além destas fontes de informação, é válido ressaltar que os planos de informação criados para a infra-estrutura e os limites da área urbana também foram, na medida do possível, complementados pela interpretação da imagem mencionada.

Todos os arquivos gerados foram georreferenciados a partir do sistema de referências UTM-23s, que adota a Projeção Universal transversa de Mercator, com 
origem da quilometragem no Equador e Meridiano $45^{\circ} \mathrm{W}$. Gr (acrescidas as constantes $10000 \mathrm{~km}$ e $500 \mathrm{~km}$, respectivamente), e datum horizontal: Córrego Alegre, MG. São apresentados, juntamente com os planos de informação intermediários gerados, nos Anexos A e B.

Neste momento se mostra oportuno ressaltar a dependência entre a qualidade das informações produzidas por meio do zoneamento ambiental e a qualidade das informações primárias, especialmente no que diz respeito ao refinamento das informações produzidas, dada a escala em que se apresentam os dados de entrada.

\subsection{A elaboração do zoneamento ambiental}

Além das informações básicas necessárias à elaboração do zoneamento ambiental para a área de estudo, referentes aos fatores ambientais considerados relevantes para a avaliação da aptidão do território para a instalação de uma determinada atividade, uma série de estudos poderia ser realizada com o intuito de gerar subsídios que permitissem um aprofundamento na discussão referente às potencialidades apresentadas e, consequentemente, facilitassem o processo de tomada de decisão - por parte do poder público - relativa à definição dos rumos a serem adotados para nortear o desenvolvimento do município.

Especificamente envolvendo a gestão dos recursos hídricos, destacam-se os temas relacionados ao risco de contaminação das águas sub-superficiais (vulnerabilidade do aqüífero) e ao risco de assoreamento dos corpos d'água encontrados no município, que também são avaliados no presente trabalho.

De forma resumida, a elaboração do zoneamento ambiental proposto para o município de São Carlos apresenta a seguinte estruturação: 


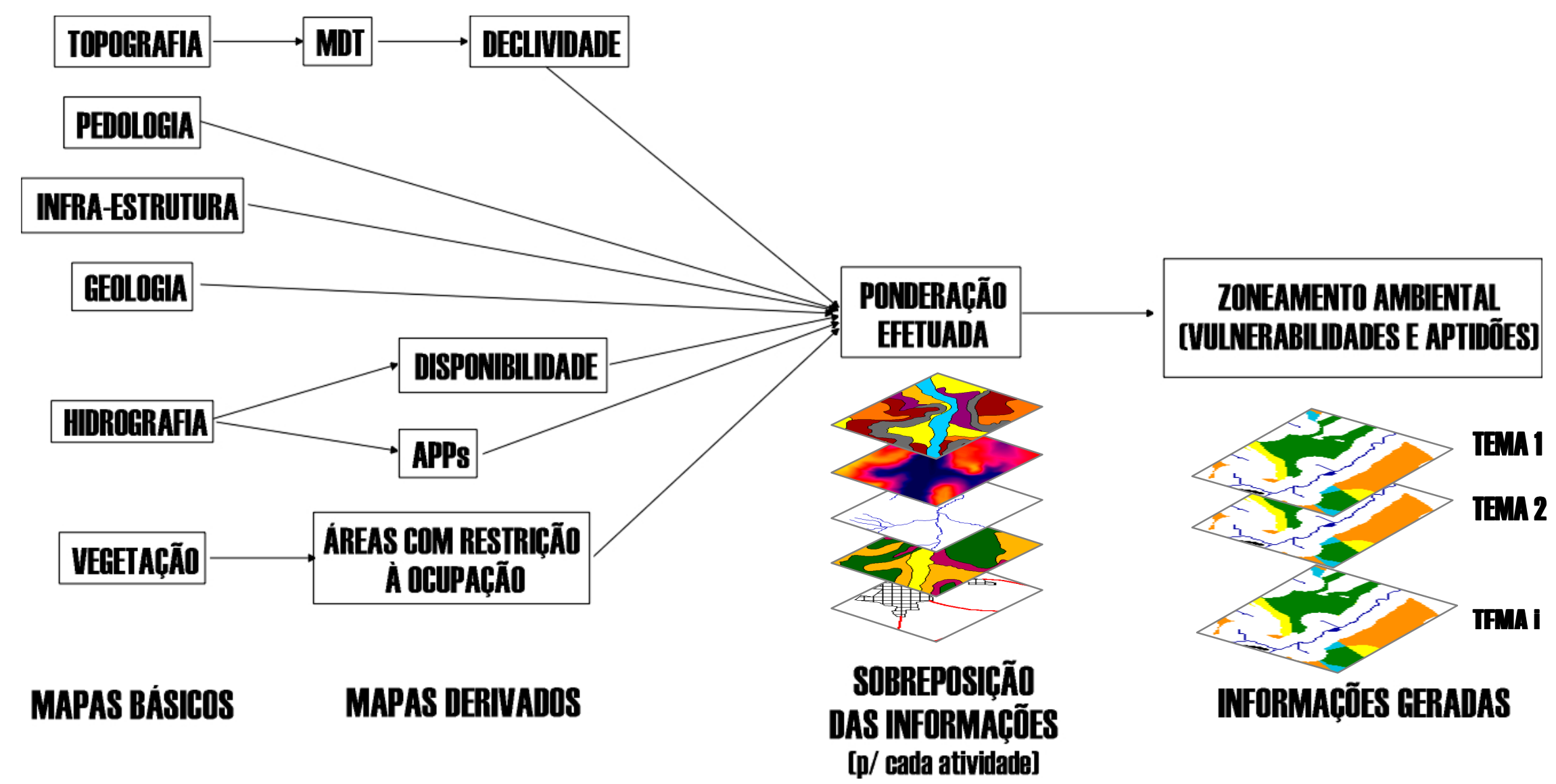

FIGURA 5: Diagrama de execução do estudo de zoneamento ambiental efetuado 
As metodologias e ponderações adotadas - procurando-se reproduzir algumas metodologias encontradas na literatura - para a execução de cada uma das avaliações efetuadas, são apresentadas a seguir. O presente trabalho não tem a pretensão de efetuar uma revisão metodológica com relação aos temas, uma vez que todas as ponderações utilizadas já foram, de alguma forma, avaliadas pela academia.

\subsubsection{Suscetibilidade à erosão.}

No presente trabalho efetua-se uma avaliação relativa à erosão causada pela desagregação das partículas do solo causada pelo escoamento superficial, empregando-se uma metodologia baseada nos trabalhos de RANIERI (1996), que se mostra apropriada para esta escala de trabalho e para este objetivo, e RANIERI (2000). De acordo com BERTONI \& LOMBARDI (1990), a erosão deste tipo tem grande influência sobre a qualidade e disponibilidade dos recursos hídricos, pela possibilidade de assoreamento dos corpos d'água e pela poluição causada, seja pelo aporte de sedimentos ou pelo carreamento de poluentes provenientes de fontes difusas.

Para a geração do mapa síntese de suscetibilidade à erosão é aplicado um método qualitativo, considerado mais apropriado para grandes áreas, nas quais se deseja efetuar uma avaliação com o intuito de ser considerada no planejamento do uso do solo (RANIERI, 1996).

A geração do mapa de suscetibilidade à erosão leva em consideração somente dois fatores: a declividade do terreno e o tipo de solo existente (considerando-se apenas os grandes grupos). Além deste fatores, a intensidade da chuva e o tipo de cobertura do solo existente também influenciam diretamente no grau de erosão sofrido (BERTONI \& LOMBARDI, 1990), contudo, ao se desconsiderar o tipo de uso do solo, e supondo uma intensidade de chuva uniforme para todo o território avaliado, supõe-se que o resultado obtido reflete uma situação que se aproxima da vulnerabilidade "natural" à erosão apresentada pelo solo.

A ponderação efetuada para os fatores considerados é aplicada conforme a tabela 1, apresentada a seguir. 
TABELA 1 - Ponderação aplicada para a determinação da suscetibilidade à erosão

\section{Tipo de solo Classe de declividade}

\begin{tabular}{cccccc} 
& 0 a $2 \%$ & 2 a $5 \%$ & 5 a $10 \%$ & 10 a $20 \%$ & $>20 \%$ \\
$L R$ & B & B & B & A & MA \\
$L E$ & B & B & B & A & MA \\
$L V$ & B & B & M & A & MA \\
$\boldsymbol{P V}$ & M & A & A & MA & MA \\
$T E$ & B & B & M & A & MA \\
$\boldsymbol{A Q}$ & M & M & A & MA & MA \\
$L i$ & M & A & MA & MA & MA \\
$H i$ & NS & NS & NS & NS & NS \\
\hline & & & & Fonte: (RANIERI, 2000)
\end{tabular}

Em que:

$$
\begin{aligned}
& \text { LR - Latossolo Roxo; } \\
& \text { LE - Latossolo Vermelho Escuro; } \\
& \text { LV - Latossolo Vermelho Amarelo; } \\
& \text { PV - Podzólico Vermelho Amarelo; } \\
& \text { TE - Terra Roxa Estruturada; } \\
& \text { AQ - Areias Quartzosas Profundas; } \\
& \text { Li - Solos Litólicos; } \\
& \text { Hi - Solos Hidromórficos. }
\end{aligned}
$$

\subsubsection{Risco de contaminação de águas subterrâneas.}

GRECCHI (1998), em sua dissertação de Mestrado, apresenta uma metodologia - aplicada para a região de Piracicaba - para a determinação da vulnerabilidade do aqüífero em relação à contaminação das águas sub-superficiais (aqüífero livre), que permite estabelecer as áreas mais frágeis em termos de 
infiltração de contaminantes, a partir das características do meio físico. Assim, para ilustrar, áreas com solos permeáveis, pouco espessos e com declividades baixas são consideradas muito favoráveis à infiltração (alta vulnerabilidade).

Os fatores considerados são: permeabilidade e espessura dos materiais inconsolidados, declividade do terreno, densidade hidrográfica e substrato rochoso. Para cada um destes fatores é estabelecida uma hierarquização relativa à condição de vulnerabilidade; sendo assim, por exemplo, aos terrenos arenosos é atribuído um fator que indica uma maior vulnerabilidade à infiltração, ao contrário dos terrenos argilosos.

A ponderação adotada para os fatores considerados foi efetuada a partir das considerações apresentadas pela referida autora, após sofrerem as devidas adaptações, dadas as condições do presente trabalho.

\section{- Permeabilidade:}

O trabalho de GRECCHI (op. cit.) parte de ensaios de granulometria efetuados por PEJON $\sqrt{12}$ (1992) para estimar a permeabilidade do material, e estabelecer uma hierarquização para as combinações de solos e substratos rochosos encontradas em sua área de estudo.

No caso do presente trabalho, devido à inexistência estudos que permitam repetir o procedimento utilizado, opta-se por considerar os diferentes teores de argila encontrados em função do tipo de solo para estimar a permeabilidade. Baseado nos trabalho de MAGNANI et al. (1999) e RANIERI (2000), a ponderação adotada é estabelecida conforme a tabela 2:

\footnotetext{
${ }^{12}$ PEJON, O. (1992). Mapeamento geotécnico regional da folha de Piracicaba-SP (escala 1:100.000): estudo de aspectos metodológicos, de caracterização e de apresentação dos atributos. São Carlos, 224 p. Tese (Doutorado). Escola de Engenharia de São Carlos, Universidade de São Paulo.
} 
TABELA 2 - Ponderação adotada para o fator permeabilidade

\begin{tabular}{cc} 
Permeabilidade (vulnerabilidade) & tipo de solo \\
\hline BAIXA & $\mathrm{LR}, \mathrm{TE}$ \\
MÉDIA & $\mathrm{LV}, \mathrm{LE}, \mathrm{PV}$ \\
ALTA & $\mathrm{AQ}, \mathrm{Li}$ \\
MUITO ALTA & $\mathrm{Hi}$ \\
\hline
\end{tabular}

Fonte: adaptado de MAGNANI et al.(1999) e RANIERI (2000)

- Espessura dos materiais inconsolidados:

De acordo com GRECCHI (op. cit.), ao considerar-se a espessura isoladamente, pode-se afirmar que quanto mais espesso for o material sobre o lençol freático, menor será a vulnerabilidade à contaminação do aqüífero.

No trabalho efetuado pela autora, foi considerado que ocorre uma coincidência entre as áreas de solo espesso e a existência de zonas não-saturadas também espessas.

No presente trabalho, novamente devido à ausência de dados concretos com relação à espessura dos materiais, agrupa-se os tipos de solo em 3 classes de espessura a partir das considerações apresentadas por OLIVEIRA \& PRADO (1984) com relação à profundidade dos solos encontrados na região de São Carlos, conforme a tabela 3.

TABELA 3 - Classes de vulnerabilidade para o fator espessura dos materiais, considerando-se a profundidade dos solos

\begin{tabular}{|c|c|c|}
\hline Profundidade & $\begin{array}{c}\text { Classe de } \\
\text { vulnerabilidade }\end{array}$ & Tipo de solo \\
\hline Muito profundo & BAIXA & LR, LE, LV \\
\hline $\begin{array}{l}\text { Moderadamente profundo } \\
\text { a profundo }\end{array}$ & MÉDIA & $A Q, T E, P V$ \\
\hline Rasos & ALTA & $\mathrm{Li}, \mathrm{Hi}$ \\
\hline
\end{tabular}

Fonte: baseado em OLIVEIRA \& PRADO (1984) 


\section{- Substrato rochoso:}

A ponderação referente ao substrato rochoso da área de estudo tem como objetivo considerar possíveis áreas de recarga de aqüífero, bastante significativas no contexto regional. No caso do presente trabalho, baseado nas informações relativas à descrição do substrato rochoso encontradas em IPT (1981) e IPT (2000), compõe-se a tabela 4:

TABELA 4 - Classes de vulnerabilidade adotadas para o fator substrato rochoso

$$
\text { Classes de vulnerabilidade Substrato rochoso }
$$

BAIXA

MÉDIA

ALTA

MUITO ALTA

não aplicável

formação Serra Geral ${ }^{* 1}$, magmatitos básicos cobertura da serra de São Carlos ${ }^{* 2}$

formações Botucatu e Pirambóia

depósitos aluviais

Fonte: baseado em IPT (1981) e IPT (2000)

\footnotetext{
${ }^{* 1}$ Trata-se de uma formação basáltica, porém devido ao fato de ser comum a existência de
} fraturas foi considerado que apresenta uma vulnerabilidade média.

*2 São formações descritas como "coberturas sedimentares, (...), arenitos conglomeráticos", de acordo com IPT (1981), o que poderia justificar uma classificação mais rigorosa, porém observa-se que o aqüífero apresenta uma extensão limitada e descontínua (IPT, 2000).

- Declividade e densidade hidrográfica:

Estes fatores influenciam diretamente o escoamento superficial e conseqüentemente a infiltração: quanto maior forem estes fatores mais dificultoso será a possibilidade de infiltração e menor a vulnerabilidade apresentada.

As classes de vulnerabilidade, adotadas em função da declividade são apresentadas na tabela 5 , a seguir: 
TABELA 5 - Classes de vulnerabilidade adotadas para o fator declividade

\section{Classe de vulnerabilidade Intervalos de declividade}

BAIXA

MÉDIA

ALTA acima de $15 \%$

de 5 a $15 \%$;

de 0 a $5 \%$;

Fonte: GRECCHI (1998)

Com relação à densidade hidrográfica, a mesma foi calculada levando-se em consideração o número de canais de primeira ordem dividido pela área da bacia considerada, resultando na densidade de drenagem, em [canais $/ \mathrm{km}^{2}$ ].

O número de canais de primeira ordem foi estimado considerando-se a realidade do presente trabalho, uma vez que a escala utilizada (1:50.000) para a obtenção do deste número não oferece o detalhamento necessário para uma aplicação satisfatória deste fator. Sendo assim, após uma estimativa da relação entre o número de canais de primeira ordem contados a partir da escala 1:50.000 e o mesmo número contado num mapa elaborado em escala 1:10.000, obtém-se um fator que permite estimar quantos canais de primeira ordem seriam contados em uma escala mais detalhada. Dessa maneira, considera-se que o número de canais de primeira ordem é $45 \%$ maior do que o efetivamente contado a partir da escala 1:50.000.

A ponderação adotada para o fator densidade hidrográfica - a partir da ponderação encontrada em GRECCHI (op. cit.) - implica nas seguintes classes de vulnerabilidade, tabela 6 :

TABELA 6 - Classes de vulnerabilidade adotadas para o fator densidade hidrográfica

\section{Classe de vulnerabilidade Densidade hidrográfica}

BAIXA

MÉDIA

ALTA acima de 4 canais por $\mathrm{km}^{2}$

de 2 a 4 canais por $\mathrm{km}^{2}$

de 0 a 2 canais por $\mathrm{km}^{2}$ 
Como forma de se efetuar a ponderação e o cruzamento referente aos fatores considerados, utilizou-se o módulo $\mathrm{MCE}^{13}$ (multi criterial evaluation), disponível no software empregado no presente trabalho, adotando-se os parâmetros sugeridos por GRECCHI (1998), tabela 7:

TABELA 7 - Pesos atribuídos aos fatores considerados para estimar a vulnerabilidade do aqüífero

\begin{tabular}{lc} 
Fator & $\begin{array}{c}\text { peso atribuído } \\
(\Sigma=1)\end{array}$ \\
\hline Permeabilidade & 0,2222 \\
Espessura & 0,2222 \\
Geologia & 0,2222 \\
Declividade & 0,2222 \\
Densidade Hidrográfica & 0,1111 \\
\hline
\end{tabular}

Fonte: GRECCHI (1998)

\subsubsection{Risco de assoreamento dos corpos d'água superficiais.}

Baseado no trabalho de FONTES (1997), a avaliação efetuada procura estimar o risco de assoreamento para os corpos d'água superficiais combinado com a presença ou a ausência da vegetação ciliar. Para tanto, procurou-se identificar considerando as áreas de preservação permanente (APPs) no entorno dos cursos d'água e de reservatórios - os locais que apresentassem alta suscetibilidade à erosão e que estivessem desprovidos de cobertura vegetal. Entende-se que, para uma determinada bacia hidrográfica, considerando uma certa quantidade de sedimentos carreados pelo escoamento superficial, os corpos d'água estariam tão mais protegidos quanto maior for a presença de cobertura vegetal em suas margens, uma vez que a vegetação, nesse caso, serviria para dificultar o aporte de sedimentos no corpo d'água e evitar a erosão de suas margens.

\footnotetext{
${ }^{13}$ O módulo MCE é uma ferramenta encontrada no software utilizado no presente trabalho, que possibilita a realização de uma avaliação multi-criterial a fim de se tomar uma decisão entre diversas alternativas, baseado em critérios definidos e atribuindo-se alguns parâmetros aos fatores considerados que reflitam sua importância em relação à avaliação efetuada. No caso apresentado, os parâmetros assumidos mostram que os fatores considerados têm a mesma importância relativa, exceto o fator densidade hidrográfica (que possui a metade do peso atribuído aos outros). Ressalta-se a necessidade de que a soma dos fatores atribuídos seja igual a 1.
} 
Para a realização desta avaliação, é gerado um plano de informação indicando as áreas consideradas como APP, de acordo com a legislação vigente (Código Florestal, Lei n. ${ }^{\circ} 4771 / 65$, alterada pela Lei n. ${ }^{\circ} 7803 / 89$, e Resolução CONAMA n. ${ }^{\circ}$ 004/85). Considera-se como APP as faixas compreendidas a uma distância de 30 metros a partir das margens de cursos d'água de até 10 metros de largura, de 100 metros a partir das margens de cursos d'água cuja largura seja de 50 a 100 metros (o que, para o presente estudo, recai sobre o rio Mogi-Guaçu), de 50 metros a partir das nascentes, e de 100 metros ao redor de reservatórios.

Reclassificando-se o mapa de suscetibilidade à erosão, obtido numa etapa anterior, de modo a considerar somente duas classes de suscetibilidade (alta composta pelas classes de muito alta e alta suscetibilidade, e baixa - composta pelas classes de média e baixa suscetibilidade), e sobrepondo-o ao plano de informação gerado anteriormente (APPs), obtém-se o mapa indicativo do risco de assoreamento dos corpos d'água superficiais para o território estudado, denominado nesta etapa de RISCO.

Numa etapa final, considerando que a presença de vegetação natural poderia minimizar ao máximo o risco de degradação dos corpos d'água, uma vez que impediria a erosão de suas margens, foram sobrepostos os mapas VEGETAÇÃO e RISCO, gerando o mapa síntese denominado "Risco de assoreamento dos corpos d'água superficiais - Prioridade de recomposição da mata ciliar".

A figura 6 ilustra o procedimento adotado para a execução desta etapa:

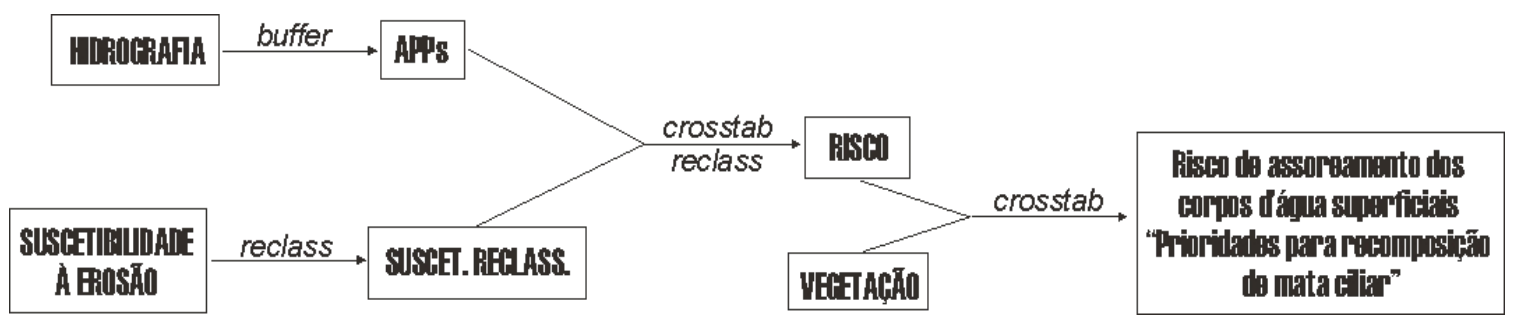

FIGURA 6: Diagrama esquemático para a determinação do risco de assoreamento dos corpos d'água superficiais 


\subsubsection{Determinação da aptidão para a instalação de atividades industriais}

O procedimento para a determinação de locais aptos a receber a instalação de atividades industriais é executado com o intuito de determinar a aptidão apresentada pelo território do município com relação à instalação de empreendimentos industriais, usuários dos recursos hídricos.

Para esta avaliação, baseado no trabalho de MAGNANI et al. (1999), considera-se os seguintes fatores ambientais: declividade, pedologia, geologia, vegetação natural, infra-estrutura e hidrografia (considerando, num primeiro momento, apenas as restrições legais) ${ }^{14}$. São ponderados, em função de suas características, de acordo com sua influência no processo de instalação de uma indústria, levando-se em consideração as fases de instalação e operação, fundamentalmente.

Tome-se, por exemplo, o fator pedologia (tipos de solo): para a instalação de uma indústria, ou de um distrito industrial, conforme o presente estudo de caso, pode ser necessário a execução de uma obra de grande porte, o que requereria a verificação da estabilidade do solo, ou uma grande movimentação de terra, no caso de ser necessário o aterramento do local. Isso significa que solos que apresentam uma resistência maior à erosão possuem uma aptidão maior para a instalação da referida indústria. Além disso, durante a fase de operação, muitas vezes (devido a diversos fatores) pode ocorrer a deposição de algum tipo de contaminante no solo, o que significa que solos menos permeáveis se mostram mais adequados. Levando-se em consideração estes aspectos, em termos de execução de obras civis e da operação de uma indústria, pode-se considerar que o teor de argila encontrado nos solos é o fator primordial decorrente desta análise - quanto maior o teor de argila, maior a resistência à erosão e menor a permeabilidade. Sendo assim, os solos são agrupados em função do teor de argila encontrado, conforme a tabela 8.

\footnotetext{
${ }^{14}$ Pode-se questionar a ausência, nesta lista, de um fator que considere os ventos predominantes no território de estudo, a fim de se avaliar um possível impacto na população que habite o entorno do local em que a atividade está instalada, principalmente pela propagação de odores provenientes das atividades industriais instaladas. A justificativa para tal "esquecimento" é dada pela ausência de informações relevantes que permitam equacionar a dinâmica climática e prever, de maneira satisfatória, a movimentação das massas de ar. Sendo assim, nesse caso, entende-se que a direção dos ventos predominantes apresenta pouca importância.
} 
TABELA 8 - Ponderação para o fator pedologia

\begin{tabular}{ccc}
$\begin{array}{c}\text { Aptidão } p / \\
\text { indústrias }\end{array}$ & Teor de argila & Tipo de solo \\
\hline $\begin{array}{c}\text { RESTRITIVA } \\
\text { (nula) }\end{array}$ & - & Solos hidromórficos \\
BAIXA & de 0 a $15 \%$ & AQ, Li \\
MÉDIA & de 15 a $35 \%$ & LV, LE, PV \\
ALTA & de 35 a $100 \%$ & LR, TE \\
\hline & \multicolumn{3}{r}{ Fonte: MAGNANI et al. (1999) }
\end{tabular}

Com relação à topografia do terreno, de modo geral, é possível considerar que quanto menos íngreme apresenta melhores condições para a instalação de indústrias. De acordo com SÃO PAULO (ESTADO) (1991), considera-se as seguintes classes de declividade, tabela 9:

TABELA 9 - Ponderação para o fator declividade

\begin{tabular}{cc}
$\begin{array}{c}\text { Aptidão } p / \\
\text { indústrias }\end{array}$ & $\begin{array}{c}\text { Intervalos de } \\
\text { declividade }\end{array}$ \\
\hline BAIXA & acima de $10 \%$ \\
MÉDIA & de 5 a $10 \%$ \\
ALTA & de 0 a $5 \%$ \\
\hline
\end{tabular}

Fonte: adaptado de SÃO PAULO (ESTADO) (1991)

Ao se considerar o fator geologia, utiliza-se a mesma ponderação aplicada para a determinação do risco de contaminação de águas subterrâneas, conforme executado no item 4.4.2, considerando como restrição a instalação da indústria sobre os depósitos aluviais devido à grande permeabilidade apresentada por este substrato. Sendo assim, a ponderação referente a este fator segue a tabela 10:

TABELA 10 - Ponderação para o fator geologia

\begin{tabular}{cc}
$\begin{array}{c}\text { Aptidão p/ } \\
\text { indústrias }\end{array}$ & Geologia (substrato rochoso) \\
\hline $\begin{array}{c}\text { RESTRITIVA } \\
\text { (nula) } \\
\text { BAIXA }\end{array}$ & depósitos aluviais \\
MÉDIA & $\begin{array}{c}\text { formações Botucatu e Pirambóia } \\
\text { cobão Serra Geral, magmatitos básicos }\end{array}$ \\
ALTA & - \\
\hline
\end{tabular}


O passo seguinte refere-se à sobreposição das informações relativas a estes fatores, multiplicando os valores atribuídos aos mesmos (numa escala crescente de aptidão, o valor 0 é atribuído à classe restritiva e o valor 3 é atribuído para a aptidão alta), produzindo dessa forma o plano de informação intermediário denominado aptidão1. Os resultados refletem a aptidão do território para a instalação de atividades industriais, em função dos fatores considerados até o momento.

Como forma de se ponderar as informações contidas no plano de informação aptidão1, de modo a dar prosseguimento à avaliação pretendida, agrupou-se os resultados obtidos em 6 classes de aptidão: nula, mínima, baixa, média, média-alta e máxima, sendo que a classe de aptidão nula foi complementada pelas restrições de ordem legal (a determinação dada pela Portaria Minter n. ${ }^{\circ} 124 / 80$, de se manter um afastamento de 200 metros entre atividades potencialmente poluidoras e qualquer corpo d'água) e pela restrição à supressão dos remanescentes de vegetação natural, conforme amplamente sugerido pela literatura consultada ou pela legislação pertinente (Decreto-Lei n. ${ }^{\circ}$ 750/93; SÃO PAULO (ESTADO), 1995; SÃO PAULO (ESTADO), 1997; MITTERMEIER et al., 2000; IPT, 2000).

A metodologia empregada até esse momento é apresentada de maneira esquemática pela figura 7 :

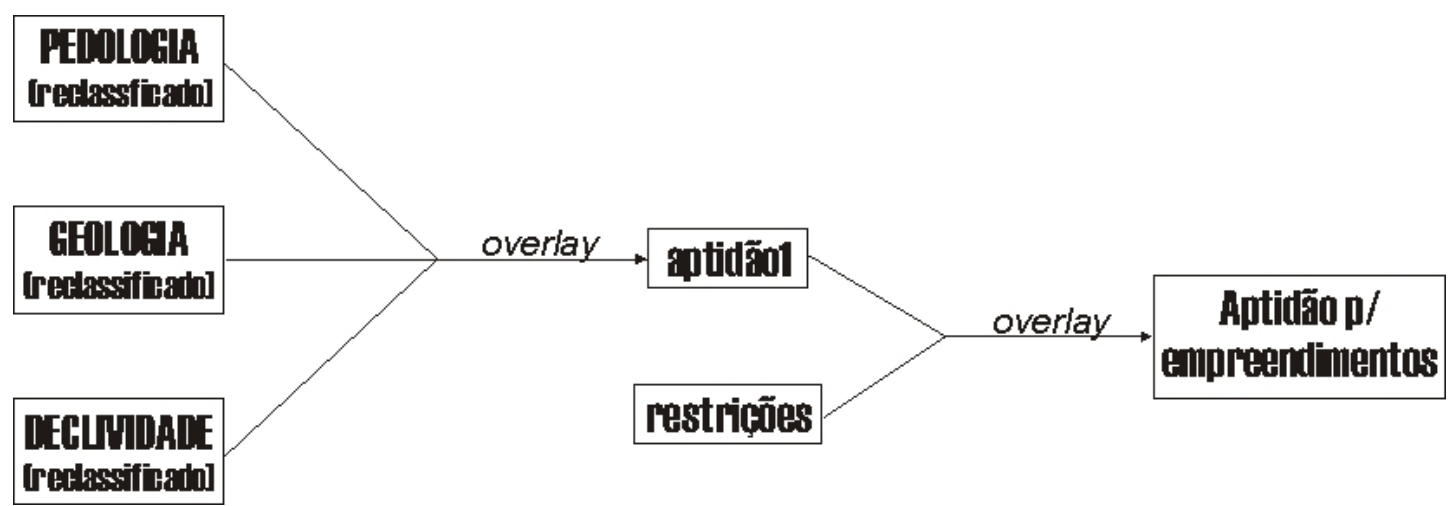

FIGURA 7: Esquema ilustrando o procedimento para a avaliação da aptidão para a instalação de empreendimentos industriais

O presente trabalho avança um pouco mais na análise da aptidão do território, ao considerar a instalação de atividades industriais que tenham o recurso hídrico como um insumo relevante para o desenvolvimento de seus processos produtivos, procurando garantir seu uso racional em termos de disponibilidade e qualidade. 


\subsubsection{Ponderação sobre os recursos hídricos}

A ponderação efetuada, referente aos recursos hídricos, observa fundamentalmente a escassez do recurso, levando-se em consideração a disponibilidade do mesmo e a solicitação exercida por uma determinada atividade.

No presente trabalho, em virtude da impossibilidade de se efetuar um levantamento de dados mais elaborado, supõe-se uma situação em que toda a oferta do recurso está - num primeiro momento - disponível, deixando de lado a demanda atual. Assim, considera-se algumas atividades que ilustram diferentes tipos de uso do recurso hídrico (industrial e domiciliar), levando-se em consideração situações de uso consuntivo (e que, portanto, diminuem a oferta do recurso), e situações que, embora não seja consumido (ou o consumo seja pouco expressivo), a oferta do recurso poderia ser comprometida em função da diminuição de sua capacidade de diluição.

Num primeiro momento, o território do município foi dividido em função de algumas das sub-bacias existentes, como mostra a figura 8 , a partir das quais é feita a ponderação apresentada.

O traçado das sub-bacias consideradas foi feito considerando os rios principais pertencentes ao território do município e considerando seus respectivos exutórios na divisa do mesmo. Em algumas ocasiões, o traçado da sub-bacia foi realizado do software BcDAEE-2000, o mesmo utilizado para estimar as vazões nos exutórios. Em outras ocasiões, este traçado foi feito a partir das informações de topografia, armazenadas em meio digital.

Neste momento, cabe destacar o fato de que este estudo tem como objetivo principal efetuar uma discussão centrada nos aspectos metodológicos apresentados, de modo que a inexistência de informações que pudessem ser utilizadas foi encarada simplesmente como uma situação conjuntural, não se tornando em momento algum um entrave para o prosseguimento do estudo. É preciso esclarecer que existe a possibilidade de se refazer todo o caminho percorrido por este estudo, refinando-se as informações e procurando-se atingir um nível mais elevado de precisão em relação à realidade ou às necessidades do novo estudo. 


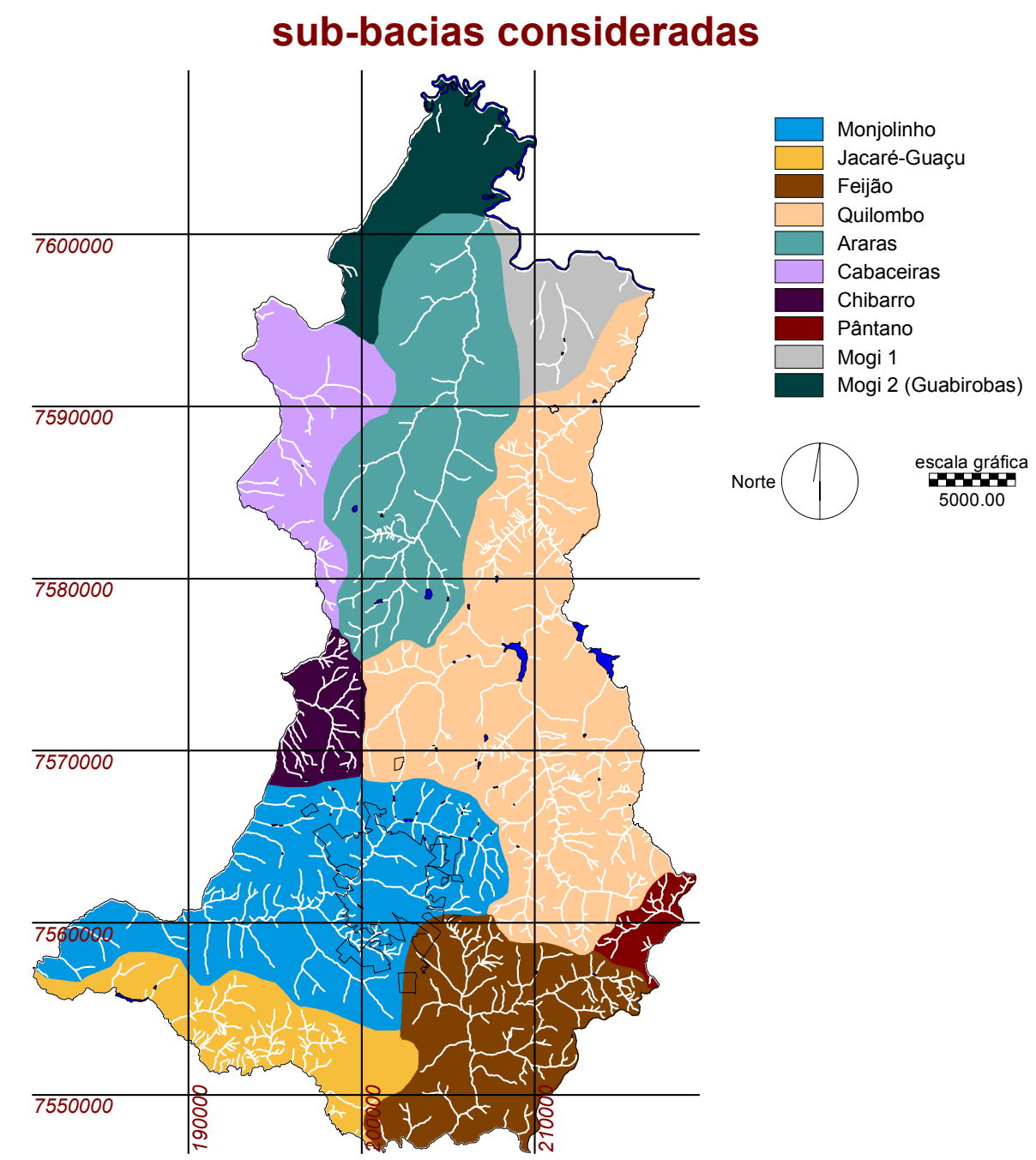

FIGURA 8: Sub-bacias consideradas para a elaboração do estudo de caso

De acordo com o Departamento de Água e Energia Elétrica (DAEE, 1988):

"Freqüentemente, nos estudos para aproveitamento dos recursos hídricos das bacias hidrográficas, o hidrólogo é convocado para avaliar a disponibilidade hídrica superficial em locais onde não existe série histórica de vazões ou, se existe, a extensão da série observada é pequena. Nesses casos, é necessário aplicar técnicas que permitam a transferência de informações de outros locais para a bacia hidrográfica em questão. Uma das técnicas de transferência de informações comumente empregada é a regionalização hidrológica".

"Por outro lado, para a adequada gestão dos recursos hídricos, especialmente nas atividades de administração como, por exemplo, na 
concessão de uso da água para uma dada finalidade, a disponibilidade hídrica precisa ser conhecida, já que o balanço demanda-disponibilidade é um indicador importante na manifestação favorável ou não à solicitação pretendida. Novamente a regionalização hidrológica é uma ferramenta que possibilita esta avaliação de maneira rápida, de acordo com a agilidade de que a administração dos recursos hídricos requer para suas decisões".

"Deve-se ter em conta ainda, que a variável hidrológica disponibilidade hídrica a ser regionalizada é função da finalidade do projeto ou uso do recurso hídricos. (...)”.

Sendo assim, as informações levantadas relativas às vazões no exutório das sub-bacias consideradas foram extraídas, em sua maioria, utilizando-se o software BcDAEE 2000 - Banco Pluviométrico, Fluviométrico e Regionalização Hidrológica do Estado de São Paulo, desenvolvido pelo DAEE, que permite estimar as vazões apresentadas por qualquer ponto do território do Estado de SP. As vazões estimadas de acordo com esse procedimento são apresentadas na tabela 11 , a seguir:

TABELA 11 - Vazões estimadas nos exutórios das sub-bacias consideradas

\begin{tabular}{|c|c|c|c|c|}
\hline \multirow[b]{2}{*}{ Sub-bacia } & \multirow{2}{*}{$\begin{array}{c}\text { área de } \\
\text { contribuiçãa } \\
\text { aproximada }\left(\mathrm{km}^{2}\right)\end{array}$} & \multicolumn{3}{|c|}{ vazão estimada } \\
\hline & & $Q_{m e ́ d}\left(m^{3} / s\right)$ & $Q_{95}\left(m^{3} / s\right)$ & $Q_{7,10}\left(m^{3} / s\right)$ \\
\hline Monjolinho $^{1}$ & 273 & 2.329 & 1.202 & 0.961 \\
\hline Jacaré-Guacu ${ }^{2}$ & 809 & 7.275 & 3.754 & 3.003 \\
\hline Feijão $^{3}$ & 250 & 2.275 & 1.174 & 0.939 \\
\hline Quilombo $^{4}$ & 466 & 6.613 & 2.401 & 1.609 \\
\hline Araras $^{4}$ & 184 & 3.128 & 1.135 & 0.761 \\
\hline Cabaceiras $^{4}$ & 143 & 2.463 & 0.894 & 0.559 \\
\hline Chibarro $^{4}$ & 50 & 0.712 & 0.259 & 0.173 \\
\hline Pântano 4 & 24 & 0.293 & 0.106 & 0.071 \\
\hline Mogi $1^{2,5}$ & 12483 & 230.938 & 83.830 & 56.187 \\
\hline Mogi 2 (Guabirobas), & 12733 & 235.434 & 85.462 & 57.281 \\
\hline Posto DAEE 4c-007 & 12291 & 227.386 & 82.541 & 55.323 \\
\hline
\end{tabular}

$1{ }^{1} \mathrm{O}$ valor da área foi obtido a partir do trabalho de ESPÍNDOLA et al. (2000)

${ }^{2}$ A área foi estimada a partir do software BcDAEE 2000

${ }^{3}$ A área foi estimada a partir do traçado da bacia publicado por SANTOS (1993)

${ }^{4} \mathrm{~A}$ área foi estimada a partir do arquivo de topografia digitalizado

${ }^{5}$ A vazão foi estimada a partir dos dados obtidos junto ao posto fluviométrico 4c-007, localizado no rio Mogi-Guaçu 
De modo a incluir em um estudo de zoneamento ambiental uma ponderação sobre os recursos hídricos, e devido ao objetivo primordial deste instrumento ser a provisão de informações que sirvam como subsídio para a tomada de decisão relativa à proposição de uma política de desenvolvimento para o território, a ponderação realizada procura avaliar qual seria a "resposta" deste fator frente a uma eventual solicitação, de modo que o poder público municipal pudesse se precaver com relação aos aspectos qualitativos e quantitativos relacionados aos recursos hídricos.

Os aspectos relativos aos recursos hídricos foram considerados, no momento da avaliação da aptidão do território para a instalação de atividades industriais, supondo-se duas situações:

I. Uma situação supõe que a solicitação sobre o recurso se dá apenas em termos de consumo, não ocorrendo nenhum tipo de lançamento. A avaliação efetuada, neste caso, trata de verificar se o volume consumido pela atividade não estaria comprometendo a disponibilidade do recurso, observados os períodos de vazão média $\left(Q_{\text {méd }}\right)$ e de vazão mínima durante $95 \%$ do tempo $\left(Q_{95}\right)$, limitados pela vazão mínima que se mantém durante 7 dias consecutivos, com período de retorno de 10 anos $\left(Q_{7,10}\right)$. Dessa maneira considera-se, para cada um dos períodos descritos, que a "oferta" do recurso $(\Delta Q)$ é dada pela vazão resultante da subtração dos valores de $Q_{\text {méd }}$ e $Q_{95}$ com o valor da $Q_{7,10}$;

II. Uma outra avaliação é efetuada no momento da verificação da capacidade de diluição (ou depuração) de um eventual efluente, lançado por uma determinada atividade, considerando as vazões média $\left(Q_{\text {méd }}\right)$, a vazão mínima que permanece $95 \%$ do tempo $\left(Q_{95}\right)$ e a vazão crítica $\left(Q_{7,10}\right)$. Procura-se avaliar, nesse caso, se a solicitação efetuada pela atividade seria compatível com as características do corpo d'água receptor, observando-se os parâmetros estabelecidos pelo enquadramento dos corpos d'água, através da resolução CONAMA 20, de 18/06/1986, associada ao Decreto Estadual n. ${ }^{\circ} 10.755$, de 22/11/1977.

Os parâmetros adotados em função dos fatores qualitativos considerados são mostrados na tabela 12 , a seguir: 
TABELA 12 - valores admitidos para OD e DBO para as classes dos corpos d'água

\begin{tabular}{ccc} 
CLASSE & OD (mín.) & DBO $_{5}$ (máx.) \\
\hline CLASSE 2 & $5 \mathrm{mg} / \mathrm{l}$ & $5 \mathrm{mg} / \mathrm{l}$ \\
CLASSE 3 & $4 \mathrm{mg} / \mathrm{l}$ & $10 \mathrm{mg} / \mathrm{l}$ \\
CLASSE 4 & $2 \mathrm{mg} / \mathrm{l}$ & - \\
\hline \multicolumn{3}{c}{ Fonte: Resolução CONAMA n. ${ }^{\circ} 20 / 86$}
\end{tabular}

Vale ressaltar que, para o território do município de São Carlos, de acordo com o Decreto Estadual n. ${ }^{\circ}$ 10.755/77, somente o córrego do Gregório e o rio do Monjolinho (após a confluência com o Gregório) são enquadrados como sendo Classe 4, e o rio Chibarro é enquadrado como classe 3. Todos os demais cursos d'água são enquadrados como classe 2.

A verificação da capacidade de diluição de efluentes apresentada por corpos d'água, feita por meio de equações descritas na literatura, se mostra bastante limitada, sobretudo devido à necessidade de se utilizar uma série de coeficientes que se mostram bastante dependentes das características do corpo d'água. Sendo assim, a avaliação efetuada neste momento é feita considerando-se somente a concentração no local do lançamento (determinada através de um simples balanço de massa considerando a mistura do efluente com a água do rio), obtidos por meio das equações (1) e (2).

$$
\begin{aligned}
& L_{0}=\frac{L_{\text {efluente }} \times Q_{\text {efluente }}+L_{\text {rio }} \times Q_{\text {rio }}}{Q_{\text {efluente }}+Q_{\text {rio }}} \\
& C_{0}=\frac{C_{\text {efluente }} \times Q_{\text {efluente }}+C_{\text {rio }} \times Q_{\text {rio }}}{Q_{\text {efluente }}+Q_{\text {rio }}}
\end{aligned}
$$

Em que:

Lo - concentração de DBO (Demanda Bioquímica de Oxigênio) da mistura, após o lançamento do efluente, [mg/l];

Co - concentração de OD (Oxigênio Dissolvido) da mistura, após o lançamento, [mg/l];

$\mathrm{L}_{\text {efluente }}, \mathrm{C}_{\text {efluente }}$ - concentrações de DBO e OD do efluente lançado, [mg/l];

$Q_{\text {efluente }}$ - vazão do efluente lançado, [l/s]; 
$\mathrm{L}_{\text {rio, }} \mathrm{C}_{\text {rio }}$ - concentrações de DBO e OD do corpo receptor antes do lançamento, $[\mathrm{mg} / \mathrm{l}]$

$Q_{\text {rio }}$ - vazão do corpo d'água receptor antes do lançamento, [l/s].

Para a estimativa dos valores de $L_{0}$ e $C_{0}$ adota-se os valores de $1.5 \mathrm{mg} / \mathrm{l}$ para a DBO inicial do corpo d'água $\left(L_{\text {rio }}\right)$ e de $6.5 \mathrm{mg} / \mathrm{l}$ para o OD antes do lançamento $\left(\mathrm{C}_{\text {rio }}\right)$, considerados representativos das condições naturais dos corpos d'água. Para os efluentes, supõe-se que apresentam uma concentração de 0 mg/l de oxigênio dissolvido, a situação mais crítica.

A avaliação da aptidão apresentada pelos recursos hídricos, com relação às atividades consideradas, é feita observando-se os parâmetros $L_{0}$ e $C_{0}$ para a mistura dos efluentes provenientes das diferentes atividades, considerando diferentes regimes de vazão $\left(Q_{\text {méd, }} Q_{95}\right.$ e $\left.Q_{7,10}\right)$. A partir daí, estabelecem-se índices que relacionam estes valores aos valores de DBO máxima e OD mínimo admitidos para as diferentes classes de corpos d'água, atribuindo-se finalmente a classe de aptidão resultante da análise efetuada, conforme a tabela 13:

TABELA 13 - Classes de aptidão preliminar, em função dos índices para DBO e OD estimados

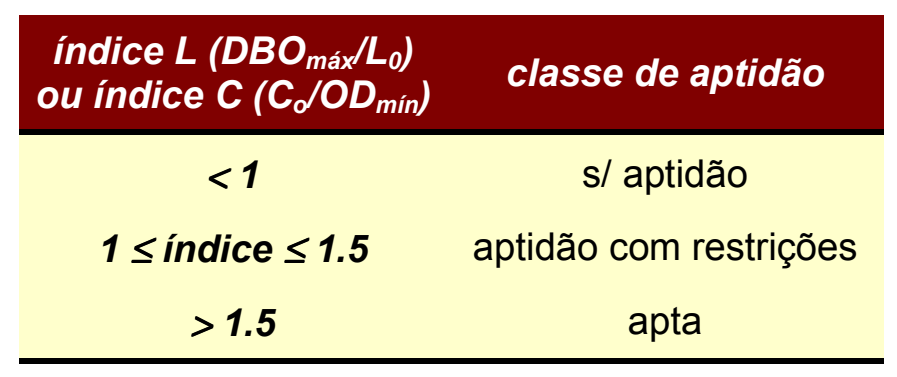

Cabe ressaltar, de modo bastante incisivo, que a diluição do Oxigênio Dissolvido apresenta como característica um decaimento, após o lançamento do efluente, e uma recuperação à jusante. Sendo assim, o valor de Oxigênio Dissolvido mínimo se dará - impreterivelmente - em um ponto mais à jusante do lançamento. Uma vez que o presente trabalho pretende avaliar a capacidade do corpo d'água em suportar um eventual lançamento - e, portanto, atribuir ao conjunto dos fatores ambientais uma aptidão para a instalação de um empreendimento - ressalta-se a necessidade de se realizar uma avaliação mais 
criteriosa com relação à curva de decaimento para o oxigênio dissolvido, determinando-se qual é a concentração mínima atingida $\left(\mathrm{C}_{\text {critica }}\right)$, nos casos em que $\mathrm{C}_{0} / \mathrm{OD}_{\min }>1$. Nesse caso, para fins de uma avaliação criteriosa, observar-se-ia as tabelas 14 e 15 :

TABELA 14 - Classes de aptidão em função dos índices para OD estimados

\begin{tabular}{cc} 
índice $C\left(C_{0} / O D_{\min }\right)$ & classe de aptidão \\
\hline$<1$ & s/ aptidão \\
$1 \leq$ índice & avaliar $\mathrm{C}_{\text {critica }}$ \\
\hline
\end{tabular}

TABELA 15 - Classes de aptidão em função dos índices para OD crítico

\begin{tabular}{cc} 
índice $C_{c}\left(C_{d} / O D_{\text {min }}\right)$ & classe de aptidão \\
$<1$ & s/ aptidão \\
$1 \leq$ índice $\leq 1.3^{1}$ & aptidão com restrições \\
$>1.3$ & apta \\
\hline
\end{tabular}

${ }^{1}$ Os extremos dos intervalos foram alterados em virtude da maior confiabilidade adquirida após uma avaliação da concentração mínima de oxigênio, de modo a refletir ainda a relação entre a concentração de saturação (aproximadamente $8,5 \mathrm{mg} / \mathrm{l}$, a $23^{\circ} \mathrm{C}$ ) e a concentração inicial adotada $(6,5$ $\mathrm{mg} / \mathrm{l})$.

Devido ao fato de que a avaliação da quantidade mínima de oxigênio dissolvido no corpo d'água depender de estudos de autodepuração, e estes necessitarem do estabelecimento de uma série de coeficientes específicos para cada corpo d'água avaliado (coeficiente de reoxigenação e velocidade do corpo d'água, fundamentalmente), esta avaliação relativa à concentração mínima de oxigênio não será efetuada neste trabalho. Deve-se entender, portanto, que os resultados apresentados têm que ser interpretados sob essa ótica, qual seja a de uma abordagem simplificada, sem considerar o fenômeno de autodepuração.

De modo semelhante, é estabelecido um índice relacionando a oferta do recurso $\left(\Delta Q=Q_{\text {rio }}-Q_{7,10}\right)$ com a solicitação em termos de consumo (vazão captada), observando-se as diferentes vazões $\left(Q_{\text {rio }}=Q_{\text {méd }}\right.$ ou $\left.Q_{95}\right)$, conforme a tabela 16: 
TABELA 16 - Classes de aptidão em função do índice para a oferta

\begin{tabular}{cc}
$\begin{array}{c}\text { índice oferta } \\
\left(\Delta Q / Q_{\text {atividade }}\right)\end{array}$ & classe de aptidão \\
$<1$ & s/ aptidão \\
$1 \leq$ índice $\leq 1.5$ & $\begin{array}{c}\text { aptidão com } \\
\text { restrições } \\
\text { apta }\end{array}$ \\
\hline
\end{tabular}

\subsubsection{Caracterização das atividades}

Baseado nas considerações de SOUZA (2000), para quem a determinação da viabilidade ambiental de empreendimentos deve conjugar as características da atividade a ser instalada com as características do meio que irá receber esta atividade (e, provavelmente, seus rejeitos), são feitas algumas avaliações relativas às seguintes atividades:

\subsection{Indústria do TIPO 1 (indústria têxti ${ }^{15}$ ):}

A água utilizada no processo produtivo é captada em poço, a uma vazão de 35 $\mathrm{m}^{3} / \mathrm{h}$ (ou $9,72 \mathrm{l} / \mathrm{s}$ ). Para atender aos padrões de lançamento, a empresa possui uma Estação de Tratamento de Efluentes que trata a água proveniente do processo produtivo, apresentando uma DBO de $400 \mathrm{mg} / \mathrm{l}$, e a lança nos coletores municipais a uma vazão de $18 \mathrm{~m}^{3} / \mathrm{h}$ (ou $5 \mathrm{l} / \mathrm{s}$ ), com uma DBO de $30 \mathrm{mg} / \mathrm{l}$.

Para fins de avaliação da aptidão do território para a instalação de uma indústria deste tipo, é considerado que a área a ser ocupada receberá um distrito industrial com capacidade para 5 indústrias cujas atividades apresentem as mesmas características. Sendo assim, supõe-se que o efluente a ser lançado apresenta uma vazão de $25 \mathrm{l} / \mathrm{s}$.

\footnotetext{
${ }^{15}$ Os dados referentes à atividade considerada foram obtidos junto a uma indústria de grande porte instalada no município de São Carlos (comunicação verbal).
} 


\subsection{Indústria do TIPO 2 (suco de laranja ${ }^{1}$ )}

As informações relativas a esta atividade dão conta que o efluente lançado após o processamento do suco de laranja apresenta uma vazão de 45,28 I/s e uma DBO de $47 \mathrm{mg} / \mathrm{l}$. Não há informação sobre o consumo de água e, novamente, a indústria não forneceu os dados relativos à OD do efluente lançado, adotando-se por essa razão o valor zero, que reflete uma situação mais severa.

Em função do porte da atividade considerada, a avaliação recai sobre a instalação de apenas uma indústria desse tipo.

\subsection{Estação de Tratamento de Esgotos}

Levando-se em consideração a necessidade do município de São Carlos dispor seus efluentes de maneira apropriada (atualmente, todo o esgoto coletado é lançado em cursos d'água no município), procedeu-se ao dimensionamento de uma eventual ETE que atendesse às necessidades do município.

A vazão de projeto estimada para a estação, considerando como solicitação mais exigente a hora de maior consumo, segue a equação (3), adaptada de CAMPOS (1990):

$$
\mathrm{Q}=\frac{\mathrm{C} \times \mathrm{k}_{1} \times \mathrm{k}_{2} \times \mathrm{N} \times \mathrm{q}}{86400}
$$

Em que:

c: relação entre a vazão de esgotos que tem acesso ao sistema coletor e a vazão de água distribuída à população (valor adotado: 0.80);

k1: coeficiente do dia de maior consumo (adotado: 1.25 );

k2: coeficiente da hora de maior consumo (adotado: 1.50 );

N: número de habitantes (200.000 habitantes);

\footnotetext{
${ }^{16}$ Estes dados foram obtidos junto a uma indústria de grande porte, instalada na região de São Carlos (comunicação verbal)
} 
q: consumo médio diário de água per capita $(269,1$ l/hab./dia, de acordo com IPT (2000)).

Os valores adotados para os coeficientes c, k1 e k2 foram obtidos junto ao trabalho de CAMPOS (1991).

Adotando-se para o fator $q$ o valor obtido para o consumo per capita obtido em IPT (2000), de 269.1 litros/hab./dia, e desconsiderando as contribuições provenientes da indústria e da infiltração na rede, temos que a ETE apresentaria uma vazão de aproximadamente 934 l/s.

Ainda de acordo com CAMPOS (1991), a DBO para esgotos sanitários varia na faixa de 150 a 400 mg/l, em média. No presente trabalho, para fins de determinação da aptidão para a instalação de ETE, é adotado o valor de $300 \mathrm{mg} / \mathrm{l}$ para a DBO do esgoto sanitário o que, admitindo-se uma eficiência de remoção de 95\%, resulta num efluente apresentando uma DBO de $15 \mathrm{mg} / \mathrm{l}$.

\subsection{Captação de água para abastecimento}

Finalizando o conjunto de atividades avaliadas, tem-se a captação de água para abastecimento. É avaliada, principalmente, a capacidade de fornecimento de água por parte das sub-bacias consideradas, supondo-se apenas uma única captação (o município utiliza, atualmente, três fontes de captação superficial, sendo que uma delas responde por aproximadamente $80 \%$ do volume captado).

De acordo com IPT (2000), tem-se que para o município de São Carlos são produzidos aproximadamente $404 \mathrm{l} / \mathrm{hab} . / \mathrm{dia}$, sendo que $50 \%$ desse volume é proveniente de captações superficiais. Disso resulta que a demanda de água para abastecimento, proveniente de captação superficial, necessária para o atendimento de uma população de 200.000 habitantes, é da ordem de $0.47 \mathrm{~m}^{3} / \mathrm{s}$.

A avaliação ora efetuada verifica a capacidade de atendimento a essa demanda, considerando que o volume captado não pode resultar numa vazão menor do que a vazão mínima considerada, $Q_{7,10}$. 


\section{RESULTADOS E DISCUSSÃO}

A partir das considerações apresentadas no capitulo anterior, apresenta-se os resultados obtidos empregando-se as ponderações adotadas para cada avaliação efetuada. Os mapas de vulnerabilidades e aptidões ora apresentados possuem caráter ilustrativo, sendo mostrados com um nível maior de detalhamento no Anexo C.

\subsection{Suscetibilidade à erosão.}

Observando os valores apresentados pela tabela 17, percebe-se que o território do município de São Carlos apresenta na maior parte de seu território uma suscetibilidade baixa à erosão (considerando-se as classes de baixa suscetibilidade e não suscetível representada pelos solos hidromórficos). O mapa obtido empregando-se a metodologia adotada pode ser visualizado na figura 9 .

TABELA 17 - Valor das áreas obtidas para as diferentes classes de suscetibilidade à erosão encontradas

\begin{tabular}{lcc} 
Classe de suscetibilidade & área $\left.\mathbf{( k m}^{2}\right)$ & \% do território \\
\hline Não suscetível & 37.1 & 3.26 \\
Baixa & 540.17 & 47.48 \\
Média & 268.54 & 23.61 \\
Alta & 195.33 & 17.17 \\
Muito alta & 96.52 & 8.48 \\
\hline
\end{tabular}




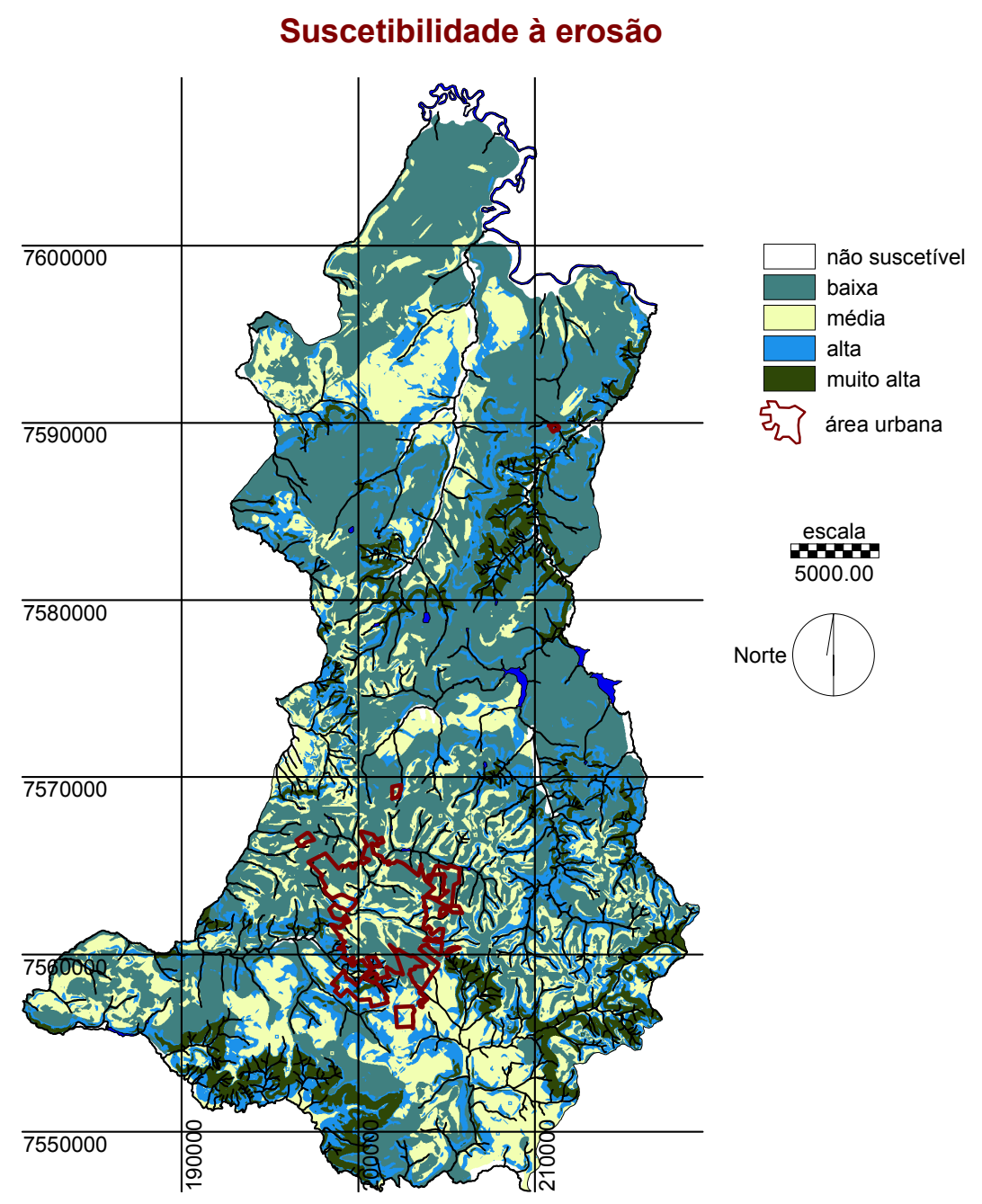

FIGURA 9: Mapa síntese de suscetibilidade à erosão para o município de São Carlos

A metodologia aplicada para a análise da suscetibilidade à erosão apresentada pelo território do município é adequada para avaliar a erosão hídrica, causada pelo escoamento superficial, bastante ligada à qualidade e disponibilidade dos recursos hídricos, seja pela possibilidade de assoreamento dos corpos d'água e pela poluição causada, seja pelo aporte de sedimentos ou pelo carreamento de poluentes provenientes de fontes difusas.

As informações provenientes desta análise indicam, de uma forma simplificada, as áreas mais adequadas para a expansão urbana, bem como as áreas nas quais é necessário um controle mais rigoroso quanto ao uso do solo, especialmente com 
relação à implantação de loteamentos que não apresentem as devidas condições de infra-estrutura (drenagem, impermeabilização do solo, áreas verdes). Sobre esse respeito, observa-se que existe uma região de expansão urbana que ocupa uma área que apresenta uma suscetibilidade à erosão alta e muito alta, representada pelo bairro Cidade Aracy (figura 10), um bairro cujas características permitem concluir que se faz necessário o estabelecimento de algumas providências em termos de prevenção da erosão, no sentido de se evitar maiores danos ao meio ambiente e à população.

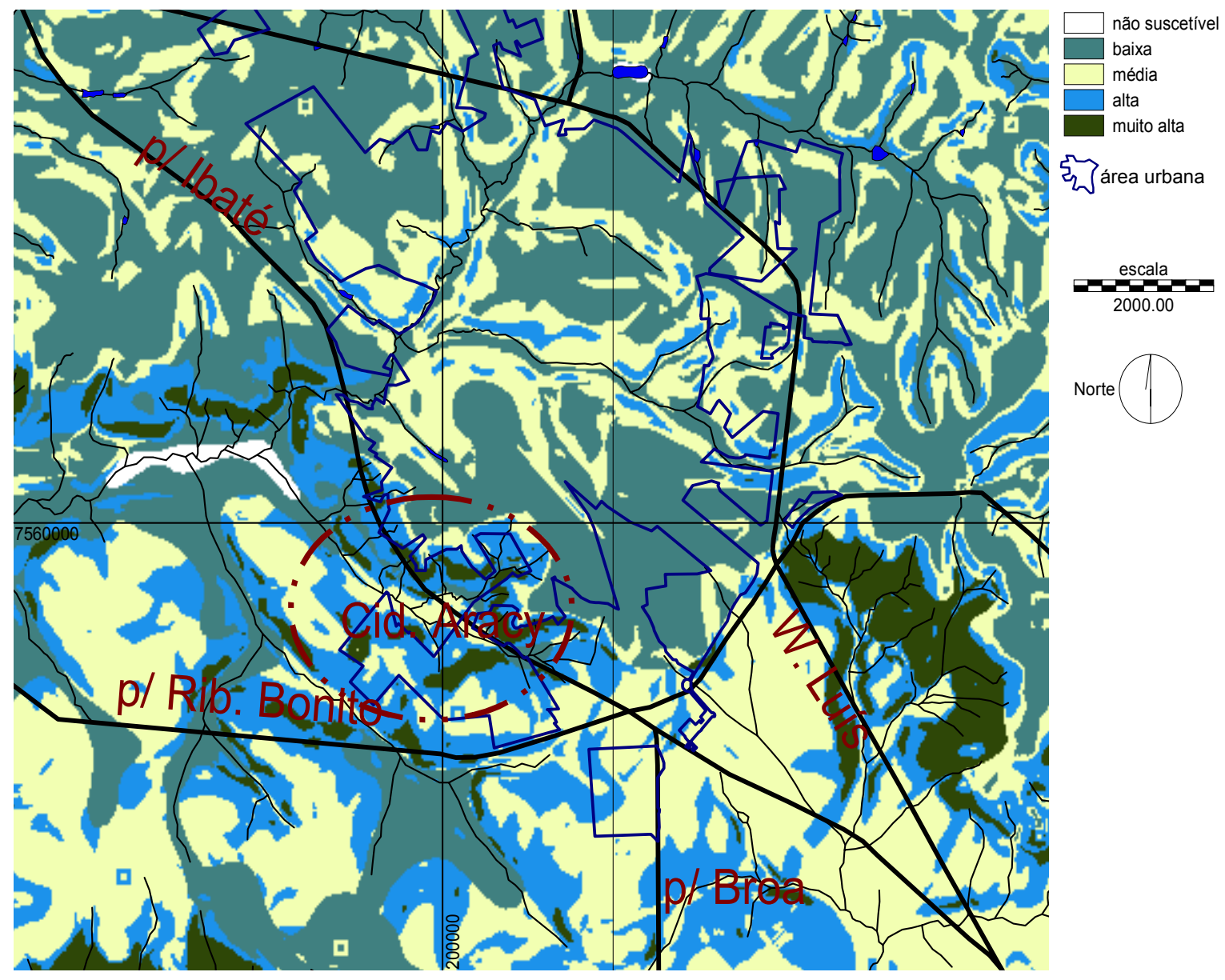

FIGURA 10: Detalhe da região do bairro Cidade Aracy

Uma outra indicação proveniente da análise do mapa obtido diz respeito à prevenção da erosão ao longo do território do município. Um dos fatores que potencializam os efeitos da erosão é a inexistência da cobertura vegetal do solo, ou 
seja, solos expostos apresentam condições muito maiores à erosão do que solos cobertos pela vegetação. Sobrepondo-se as informações relativas à cobertura vegetal do território ao mapa de suscetibilidade apresentado, observa-se que aproximadamente 54 dos $181.85 \mathrm{~km}^{2}$ do território do município classificado nas categorias de alta e muito alta suscetibilidade estão cobertos pela vegetação natural, o que indicaria uma necessidade maior de atuação do poder público no sentido de preservar os fragmentos existentes e estimular a recomposição da vegetação, especialmente nas áreas mais suscetíveis à erosão.

\subsection{Risco de contaminação de águas subterrâneas.}

O resultado da ponderação adotada para os fatores considerados durante a análise do risco de contaminação de águas subterrâneas (considerando-se o aqüífero livre) apresenta, para todo o território do município, o nível de fragilidade com relação à infiltração de contaminantes que pudessem provocar a deterioração da qualidade das águas do aqüífero.

É preciso ressaltar o caráter ilustrativo deste mapa, mostrado na figura 11, uma vez que houve a necessidade de se realizar uma série de adaptações entre a metodologia consultada e a metodologia efetivamente aplicada, o que de maneira alguma inviabiliza a utilização das informações decorrentes desta análise quando da elaboração de políticas de preservação dos mananciais subterrâneos do município, desde que se esteja ciente de suas limitações.

Observando o mapa apresentado, nota-se que, em função da ponderação adotada e da combinação dos fatores considerados, as áreas que apresentam um alto risco de contaminação do aqüífero são aquelas que apresentam declividades baixas, solo permeável e pouco espesso, bem como estão sobre um substrato rochoso considerado vulnerável em relação à infiltração de contaminantes. Aproximadamente 15\% (167,21 $\mathrm{km}^{2}$ ) do território do município apresenta uma vulnerabilidade alta à contaminação do aqüífero subterrâneo. 
Risco de contaminação de água subterrânea

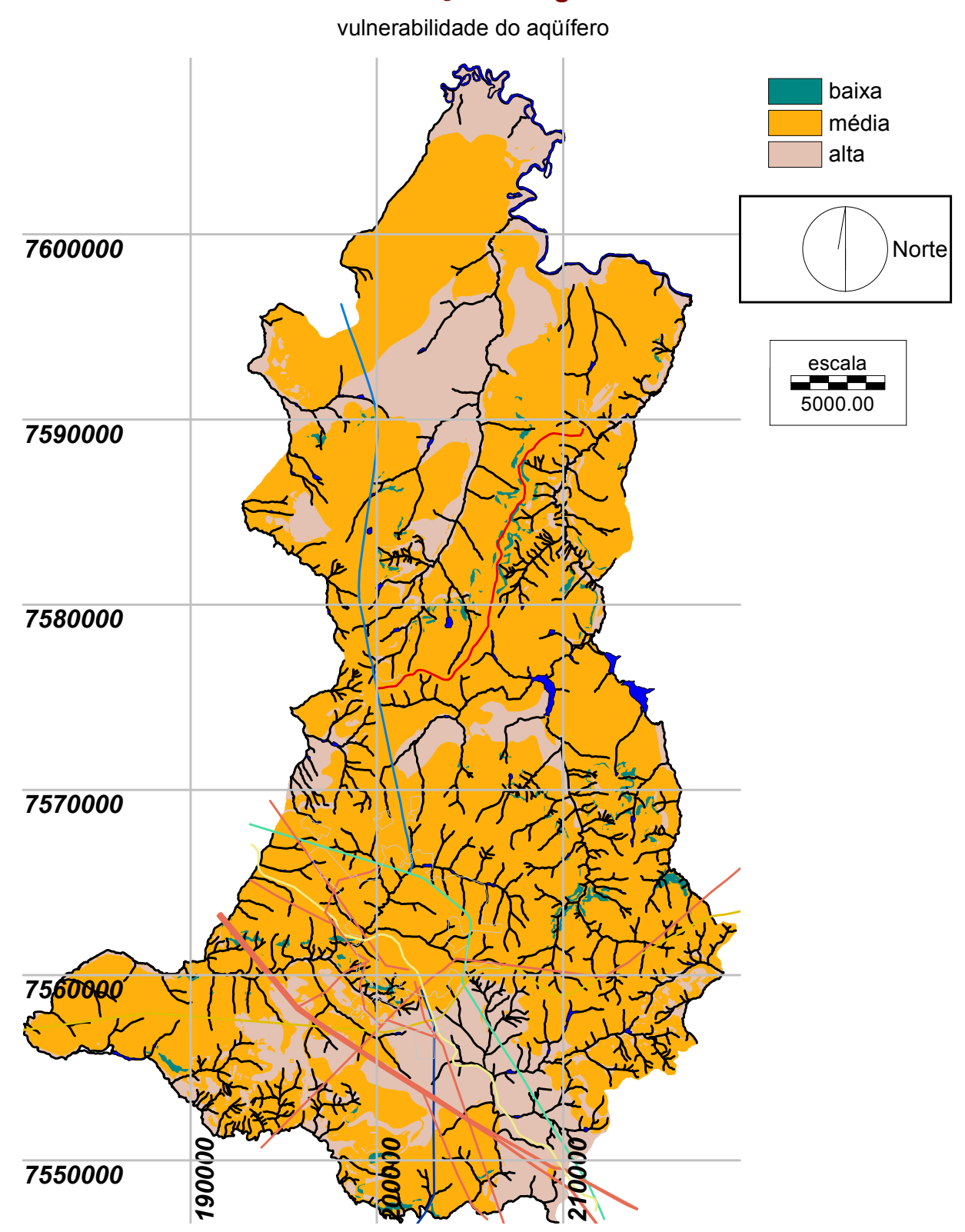

FIGURA 11: Mapa síntese de risco de contaminação de águas subterrâneas

É possível perceber, pela figura 12, que o município possui um distrito industrial e uma fábrica de motores instalados em uma área de alto risco de contaminação do aqüífero, ressaltando a necessidade, mais uma vez, de uma atuação mais rigorosa por parte do poder público no sentido de um controle acurado relativo às fontes de poluição. 


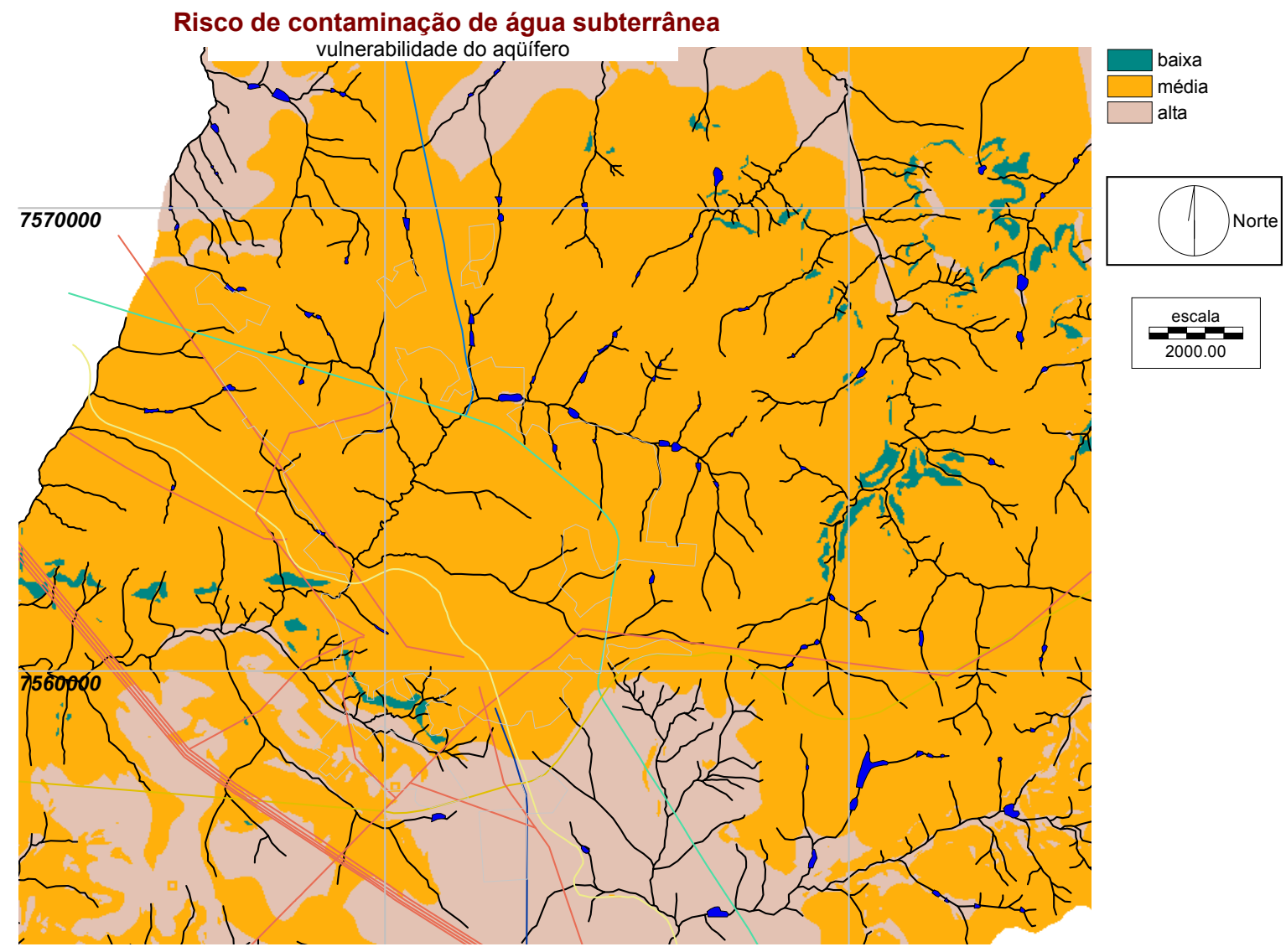

FIGURA 12: Detalhamento sobre a área urbana

\subsection{Risco de assoreamento dos corpos d'água superficiais.}

Observando-se o produto obtido pela execução da análise descrita no item 4.4.3., pode-se identificar com clareza quais trechos ao longo dos corpos d'água apresentam maior ou menor risco de assoreamento, de acordo com a metodologia adotada para este procedimento.

A tabela 18 traz o valor para as áreas de APP do município, e sua relação com as áreas cobertas por vegetação natural.

TABELA 18 - Risco de assoreamento para os corpos d'água do município

\begin{tabular}{|c|c|c|c|c|}
\hline \multirow{2}{*}{ área APP $\left(\mathrm{km}^{2}\right)$} & \multirow{2}{*}{$\begin{array}{c}\text { APP c/ cobertura } \\
\text { vegetal }\left(\mathrm{km}^{2}\right)\end{array}$} & \multicolumn{3}{|c|}{ APP s/ cobertura $\left(\mathrm{km}^{2}\right)$} \\
\hline & & maior risco & menor risco & baixo risco \\
\hline & $46.07(41.8 \%)$ & $17.53(15.6 \%)$ & $39.60(35.2 \%)$ & $9.33(8.3 \%)$ \\
\hline
\end{tabular}


Os corpos d'água que estão em situação de maior risco com relação ao assoreamento são aqueles que não apresentam cobertura vegetal ao longo de suas margens e que atravessam áreas de alta suscetibilidade à erosão. A figura 13 ilustra a situação encontrada.

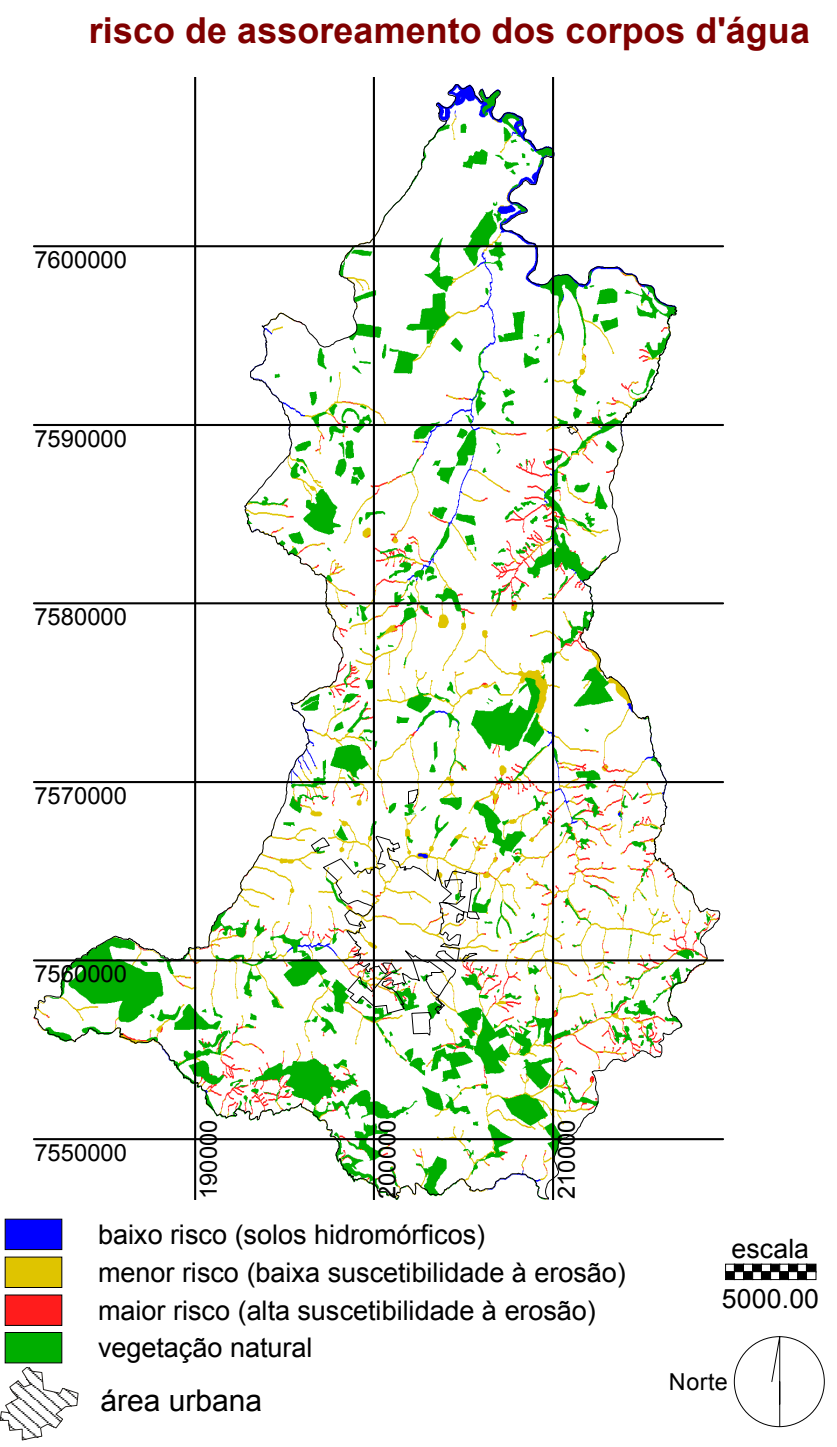

FIGURA 13: Risco de assoreamento dos corpos d'água

As informações provenientes deste mapa são úteis para se determinar ações que atuem no sentido de prevenir o assoreamento dos corpos d'água no território do município, bem como para os órgãos de fiscalização (como o DPRN, por exemplo) atuarem de maneira mais segura e eficiente no seu trabalho de assegurar a existência 
da cobertura vegetal na APPs. Ressalta-se que as informações relativas à cobertura de vegetação natural podem ser atualizadas de maneira satisfatória com o auxílio de trabalhos de campo e/ou imagens de satélite, ampliando as possibilidades de utilização dessa metodologia por parte do poder público.

\subsection{Determinação da aptidão para a instalação de atividades industriais.}

Neste momento, a discussão é fomentada pelos resultados obtidos ao ser aplicada a metodologia adotada para avaliar a aptidão do território da área de estudo com relação à instalação de empreendimentos industriais. Num primeiro momento, a resposta em termos de aptidão é obtida de maneira genérica, levando-se em consideração a capacidade do meio em suportar uma determinada atividade, que apresenta um certo nível de solicitação.

Ao se executar o esquema apresentado na figura 7 , o primeiro plano de informação obtido - denominado Aptidão1 - pode ser visualizado na figura 14, a seguir. A legenda deste mapa indica os valores obtidos após a sobreposição e multiplicação dos fatores considerados até então, e suas respectivas classes de aptidão (nula a máxima), lembrando que aos fatores considerados foram atribuídos valores representativos de suas respectivas aptidões, numa escala de 0 a 3.

O fato de não existir, de acordo com a ponderação adotada, uma classe de aptidão alta (e que, portanto, receberia o valor 3) para o fator geologia impede que seja obtida a nota máxima $(3 \times 3 \times 3)$. Sendo assim, atribui-se para o maior valor obtido (no caso, o valor 18) a aptidão máxima, chamando a atenção para o fato de que se trata do máximo local, e não o máximo que poderia ser obtido aplicando-se a mesma metodologia em outra área de estudo. 


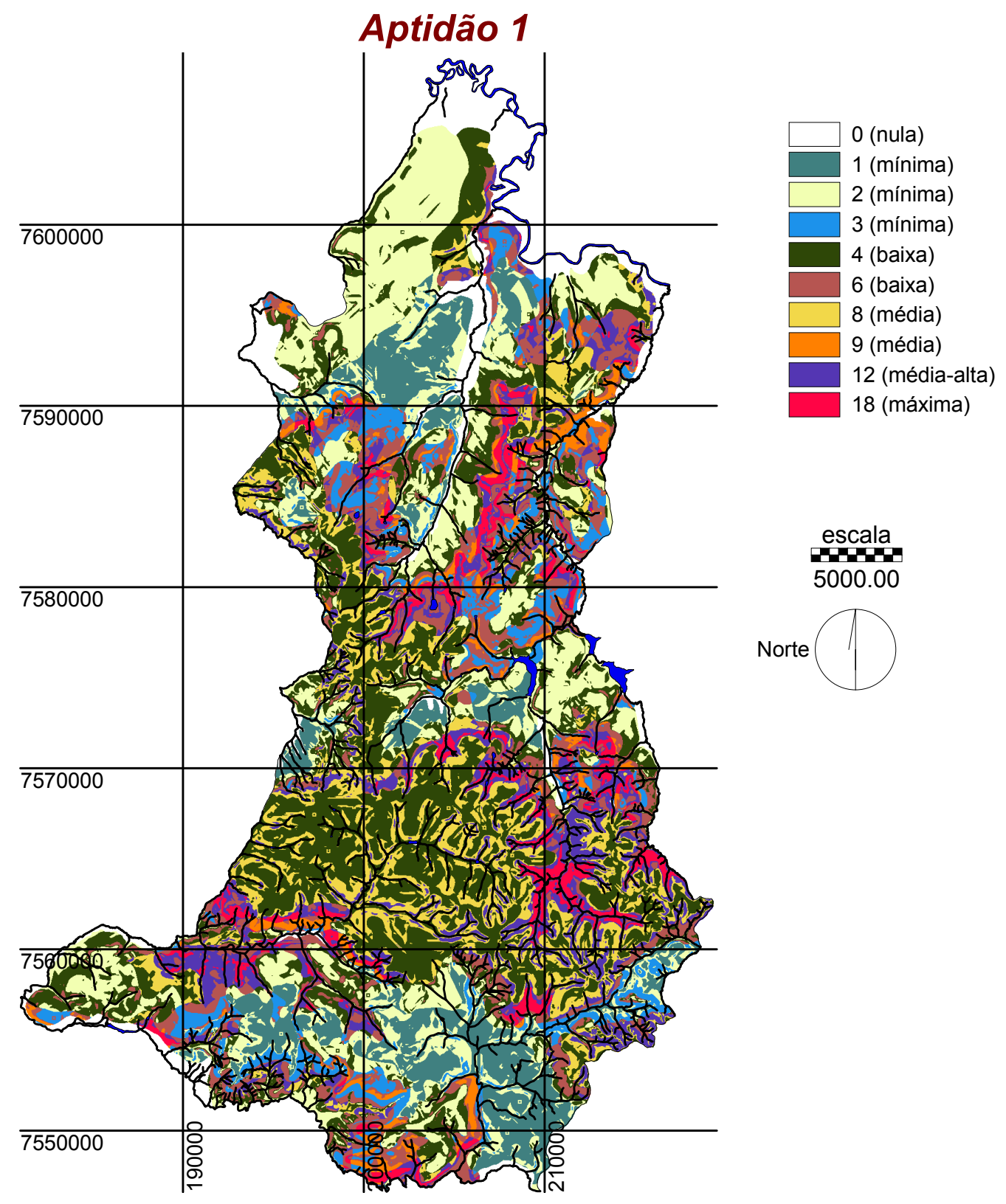

FIGURA 14: Plano de informação Aptidão1.

O plano de informação Aptidão1 é complementado pelas restrições atribuídas ao conjunto de fatores ambientais considerados na análise, nesse caso representadas pelo impedimento de se instalar atividades poluidoras a menos de 200 metros de corpos d'água e pela "sugestão" de se manter os remanescentes de vegetação natural intactos. A figura 15 ilustra a situação descrita: 


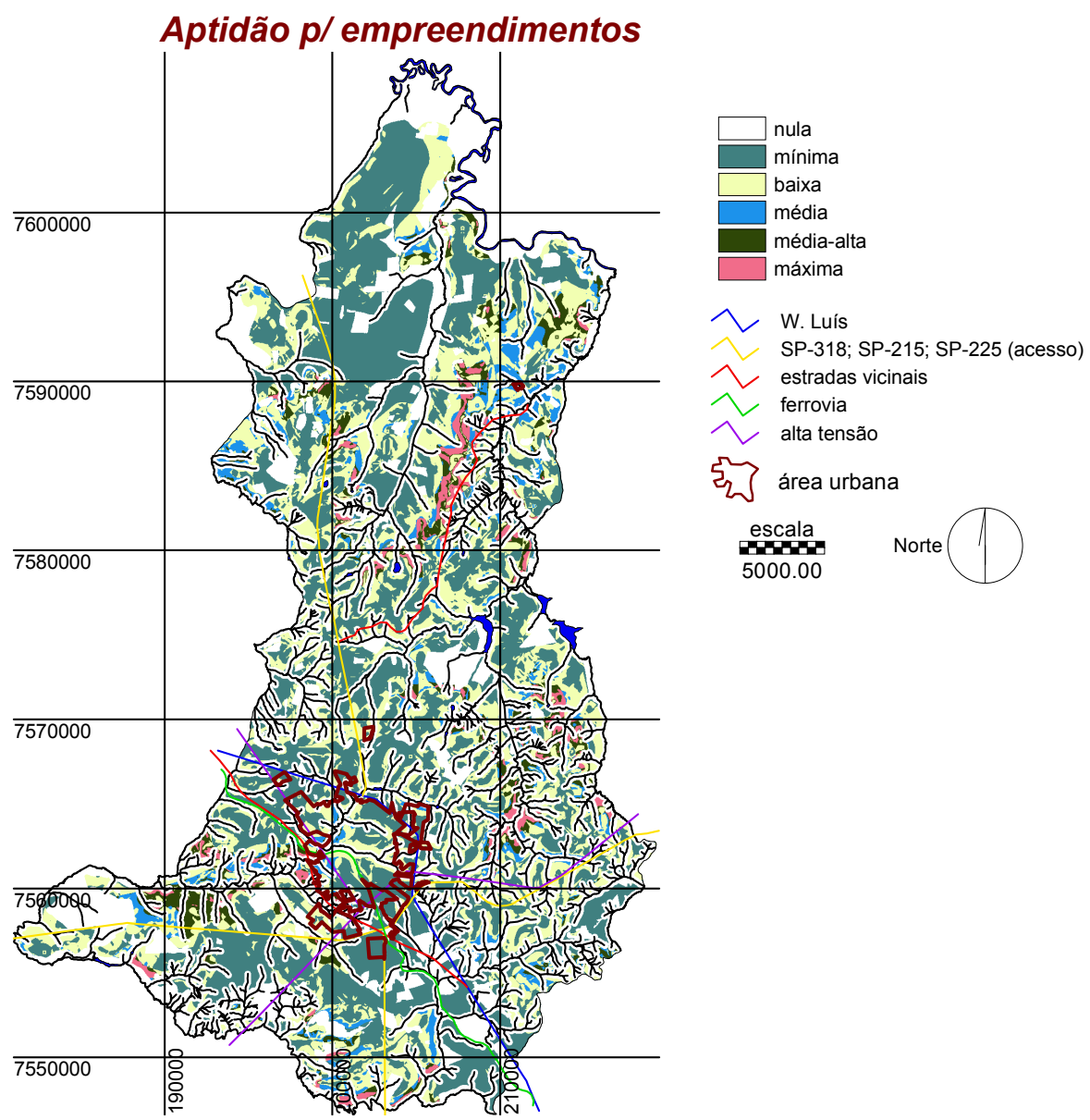

FIGURA 15: Aptidão p/ a instalação de empreendimentos.

O resultado obtido indica que para o território analisado, apenas $16.89 \mathrm{~km}^{2}$ apresenta a máxima aptidão que poderia ser obtida, e $33.33 \mathrm{~km}^{2}$ apresenta a aptidão considerada como média-alta, totalizando uma área de $50.22 \mathrm{~km}^{2}(4.41 \%)$ que poderia ser indicada como apta à instalação de empreendimentos, conforme a metodologia adotada. Para uma área de $1137.66 \mathrm{~km}^{2}$, tem-se que $513.63 \mathrm{~km}^{2}$ (ou $45.15 \%$ ) apresentam restrições à instalação de empreendimentos potencialmente poluidores.

É necessário ressaltar que a aptidão média-alta pode ser considerada apta para a instalação de empreendimentos na medida em que, em virtude da combinação das ponderações atribuídas aos fatores ambientais, é possível saber qual fator está "puxando" a sua aptidão para uma classe inferior. Esta classe de aptidão alcançou o valor 12 , o que significa uma combinação de $2 \times 2 \times 3$ na sobreposição dos fatores. 
Sabendo-se que, nesse caso, o fator geologia sempre contribui com uma classe de aptidão que apresenta o valor 2, pode-se diferenciar os casos em que o outro valor 2 é proveniente do fator pedologia ou do fator declividade, o que permitiria avaliar quais medidas deveriam ser tomadas a fim de contornar esse fato.

Uma simples observação sobre o mapa apresentado permite distinguir, para o território do município, quais são as regiões que apresentam uma maior aptidão para a instalação de empreendimentos. Ao se considerar a infra-estrutura (rodovias, ferrovia, energia) como um fator extremamente atrativo em se tratando da instalação de empreendimentos, percebe-se claramente a necessidade de se ampliar a oferta de condições que sirvam como atrativo aos empreendedores, direcionando a demanda para as regiões de maior potencial, uma vez que a infra-estrutura instalada atualmente serve geralmente às áreas de mínimo e baixo potencial.

\subsubsection{Ponderação sobre os recursos hídricos}

A partir das considerações realizadas nos itens 4.4.4.1 e 4.4.4.2., a discussão recai sobre as possibilidades de atendimento, por parte dos recursos hídricos, às solicitações exercidas por diferentes tipos de atividade. Destaca-se o fato da avaliação ser feita para diferentes períodos, considerando situações nas quais os corpos d'água apresentam as vazões $Q_{\text {méd }}, Q_{95}$ e $Q_{7,10}$.

As diferentes vazões adotadas refletem situações bastante distintas em termos da aptidão apresentada pelos recursos hídricos, quais sejam:

- $Q_{\text {méd: }}$ reflete a situação mais favorável ao longo do tempo, comparada com as demais, em termos de oferta e capacidade de diluição, sendo de duas a três vezes maior do que a vazão $Q_{95}$. Ressalta-se o fato de $Q_{\text {méd }}$ ser o resultado de uma ponderação entre os valores máximo e mínimo ao longo do período considerado, o que significa que existem períodos nos quais o corpo d'água apresenta uma vazão muito superior do que a média, e outros nos quais a vazão será bem menor (na realidade, observando os dados relativos ao posto fluviométrico DAAE 4c-007, localizado no rio Mogi-Guaçu, observa-se em algumas situações uma vazão máxima dez vezes maior do que a mínima); 
- Q95: esse valor reflete a menor vazão que se manteve durante $95 \%$ do período considerado. A utilização deste parâmetro reflete uma situação que pode ser considerada bastante rigorosa em termos de avaliação da oferta e da capacidade de diluição apresentadas pelos corpos d'água. Nos períodos em que a vazão for inferior a este valor é necessário o estabelecimento de algumas medidas, como por exemplo a retenção dos efluentes para serem lançados num período de maior vazão, ou um nível maior de eficiência no tratamento.

- $Q_{7,10}$ : se relaciona à menor vazão que se mantém por sete dias consecutivos, com período de retorno de 10 anos. É o mais restritivo dos valores utilizados, em termos de oferta e capacidade de diluição.

Uma questão sobre a metodologia utilizada para a estimativa da oferta e da capacidade de diluição por parte dos recursos hídricos merece ser discutida mais detalhadamente. A estimativa para as vazões efetuada por meio do software empregado nesta pesquisa não pode ser estendida para toda a sub-bacia avaliada, uma vez que o valor obtido por esta estimativa reflete apenas a situação encontrada no exutório das sub-bacias. De modo a refinar as informações obtidas, o território estudado poderia ser dividido em sub-bacias menores, relacionadas a trechos específicos dos corpos d'água.

A análise efetuada, da maneira como é apresentada, deve ser entendida como um exercício de demonstração da metodologia empregada, não possuindo, portanto, um caráter definitivo em termos da resposta encontrada para a avaliação da aptidão para a instalação de empreendimentos. Mesmo assim, as informações extraídas desta análise são úteis no momento da formulação de políticas de desenvolvimento, uma vez que apresentam indicativos claros da capacidade de atendimento, por parte dos recursos hídricos, das solicitações provenientes das atividades consideradas.

\subsubsection{Indústria do TIPO 1 (indústria têxtil)}

A análise sobre a solicitação sobre os recursos hídricos, para esta atividade, resulta nos valores apresentados nas tabelas 19, 20 e 21, respectivamente relativas às vazões $Q_{\text {méd }}, Q_{95}$ e $Q_{7,10}$. 
TABELA $19^{*}$ - Classes de aptidão para as sub-bacias consideradas, em função dos valores para as concentrações iniciais de DBO e OD (atividade Indústria do TIPO 1), para o período de vazão $Q_{\text {méd }}$

\begin{tabular}{ccccccc} 
Sub-bacia & $\boldsymbol{Q}_{\boldsymbol{m e ́ d}}(\mathrm{I} / \mathbf{s})$ & $\boldsymbol{L}_{\mathbf{0}}(\mathbf{m g} / \mathbf{l})$ & $\boldsymbol{C}_{\mathbf{0}}(\mathbf{m g} / \mathbf{l})$ & índice $L_{0}$ & índice $\boldsymbol{C}_{\boldsymbol{0}}$ & $\begin{array}{c}\text { Classe de } \\
\text { aptidão }\end{array}$ \\
\hline Monjolo** & 2329 & 1.80 & 6.43 & - & 3.22 & apta \\
Jacaré & 7725 & 1.59 & 6.48 & 3.14 & 1.30 & com restrições \\
Feijão & 2275 & 1.81 & 6.43 & 2.76 & 1.29 & com restrições \\
Quilombo & 6613 & 1.61 & 6.48 & 3.11 & 1.30 & com restrições \\
Araras & 3128 & 1.73 & 6.45 & 2.90 & 1.29 & com restrições \\
Cabaceiras & 2463 & 1.79 & 6.43 & 2.80 & 1.29 & com restrições \\
Chibarro & 712 & 2.47 & 6.28 & 4.05 & 1.57 & apta \\
Pântano & 293 & 4.28 & 5.87 & 1.17 & 1.17 & com restrições \\
\hline
\end{tabular}

* Não são apresentados os valores correspondentes às sub-bacias Mogi 1 e Mogi 2 devido ao fato de serem totalmente influenciadas pelo rio Mogi-Guaçu, que obviamente apresenta uma alta aptidão para a implantação das atividades consideradas.

** Não existe restrição quanto à DBO encontrada em corpos d'água classe 4

TABELA 20 - Classes de aptidão para as sub-bacias consideradas, em função dos valores para as concentrações iniciais de DBO e OD (atividade Indústria do TIPO 1), para o período de vazão $Q_{95}$

\begin{tabular}{ccccccc} 
Sub-bacia & $\boldsymbol{Q}_{95}(\mathbf{l} / \mathbf{s})$ & $\boldsymbol{L}_{\mathbf{0}}(\mathbf{m g} / \mathbf{l})$ & $\boldsymbol{C}_{\mathbf{0}}(\mathbf{m g} / \mathbf{l})$ & índice $L_{0}$ & índice $\boldsymbol{C}_{0}$ & $\begin{array}{c}\text { Classe de } \\
\text { aptidão }\end{array}$ \\
\hline Monjolo & 1202 & 2.08 & 6.37 & - & 3.18 & apta \\
Jacaré & 3754 & 1.69 & 6.46 & 2.96 & 1.29 & com restrições \\
Feijão & 1174 & 2.09 & 6.36 & 2.39 & 1.27 & com restrições \\
Quilombo & 2401 & 1.79 & 6.43 & 2.79 & 1.29 & com restrições \\
Araras & 1135 & 2.11 & 6.36 & 2.36 & 1.27 & com restrições \\
Cabaceiras & 894 & 2.28 & 6.32 & 2.20 & 1.26 & com restrições \\
Chibarro & 259 & 4.01 & 5.93 & 2.49 & 1.48 & com restrições \\
Pântano & 106 & 8.05 & 5.01 & 0.62 & 1.00 & s/ aptidão \\
\hline
\end{tabular}


TABELA 21 - Classes de aptidão para as sub-bacias consideradas, em função dos valores para as concentrações iniciais de DBO e OD (atividade Indústria do TIPO 1), para o período de vazão $Q_{7,10}$

\begin{tabular}{ccccccc} 
Sub-bacia & $\boldsymbol{Q}_{7,10}(\mathrm{I} / \mathbf{s})$ & $\boldsymbol{L}_{0}(\mathbf{m g} / \mathbf{l})$ & $\boldsymbol{C}_{0}(\mathbf{m g} / \mathbf{l})$ & índice $L_{0}$ & índice $\boldsymbol{C}_{0}$ & $\begin{array}{c}\text { Classe de } \\
\text { aptidão }\end{array}$ \\
\hline Monjolo & 961 & 2.22 & 6.34 & - & 3.17 & apta \\
Jacaré & 3003 & 1.74 & 6.45 & 2.88 & 1.29 & com restrições \\
Feijão & 939 & 2.24 & 6.33 & 2.23 & 1.27 & com restrições \\
Quilombo & 1609 & 1.94 & 6.40 & 2.58 & 1.28 & com restrições \\
Araras & 761 & 2.41 & 6.29 & 2.08 & 1.26 & com restrições \\
Cabaceiras & 559 & 2.72 & 6.22 & 1.84 & 1.24 & com restrições \\
Chibarro & 173 & 5.10 & 5.68 & 1.96 & 1.42 & com restrições \\
Pântano & 71 & 8.92 & 4.81 & 0.56 & 0.96 & s/ aptidão \\
\hline
\end{tabular}

Percebe-se que, para a atividade analisada, o fator limitante (em função da ponderação adotada) é representado pela concentração de OD apresentada pelo efluente a ser lançado. Desconsiderando-se a sub-bacia do ribeirão do Pântano, por apresentar uma área pequena (24 $\mathrm{km}^{2}$ até o exutório localizado no limite do município), e portanto receber pouca contribuição do escoamento, todas as outras podem ser classificadas como aptas em função do índice $L_{0}$, que leva em consideração a concentração de DBO na mistura.

Uma outra conclusão importante refere-se à aptidão apresentada pela sub-bacia do rio do Monjolinho: o índice $\mathrm{C}_{0}$ obtido (superior a 3.17 para as três vazões consideradas) reflete a maior permissividade do enquadramento atual do rio do Monjolinho (classe 4) em termos de concentrações admissíveis para a DBO e o OD. Caso o rio fosse enquadrado numa classe mais rigorosa, classe 2 por exemplo, o índice $\mathrm{C}_{0}$ resultante seria inferior a 1.29 , resultando numa classe de aptidão com restrições. Adianta-se que este comportamento se repete para as demais atividades avaliadas.

De forma a visualizar os resultados apresentados, as figuras 16 e 17 apresentam a distribuição das áreas de aptidão máxima e média-alta, obtidas de acordo com a 
metodologia adotada, ao longo das sub-bacias consideradas para o território do município.

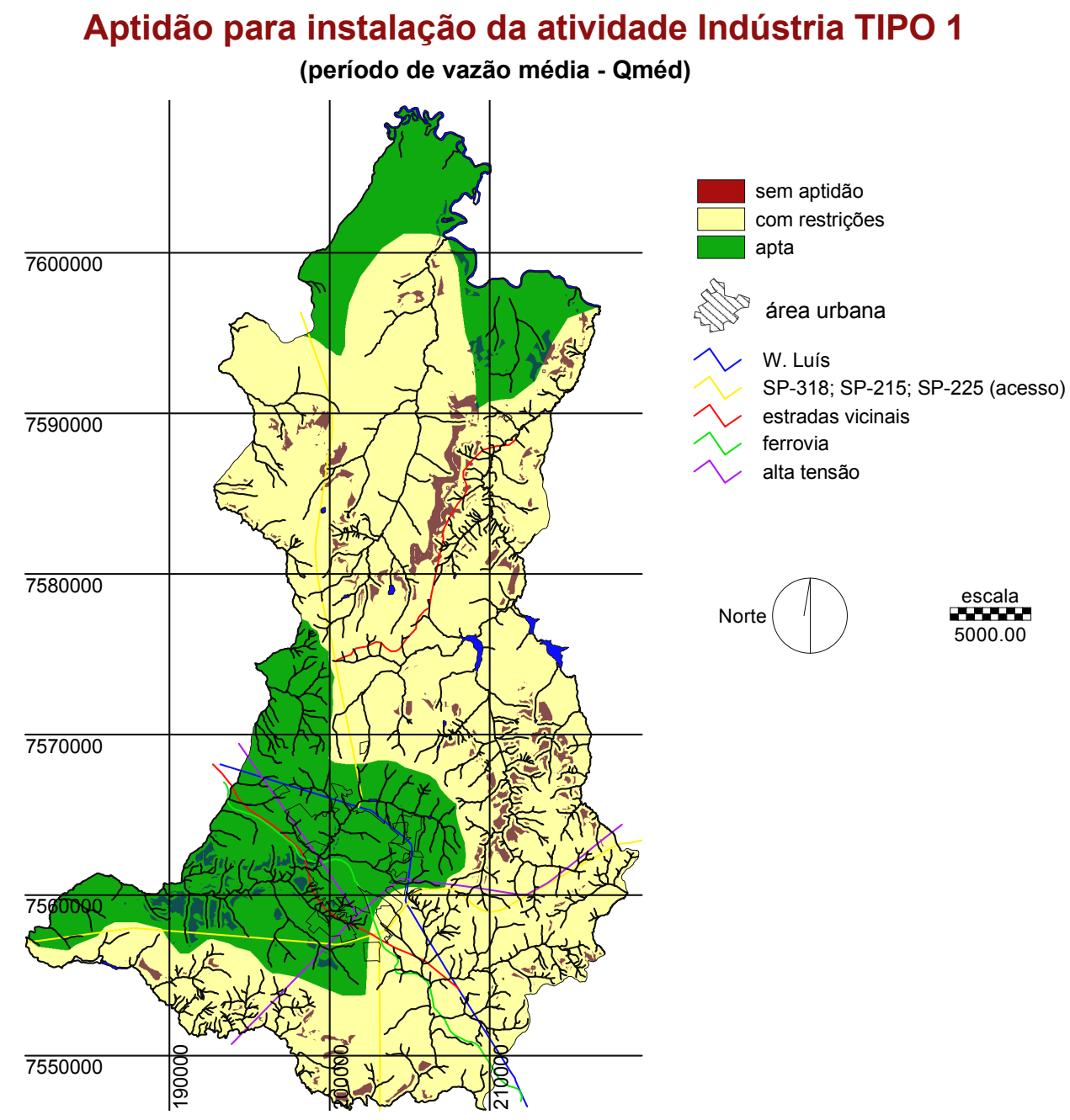

FIGURA 16: Áreas consideradas aptas para a instalação do empreendimento Indústria TIPO 1, associadas às aptidões apresentadas pelas sub-bacias em que se localizam, considerando a vazão $Q_{\text {méd }}$ 


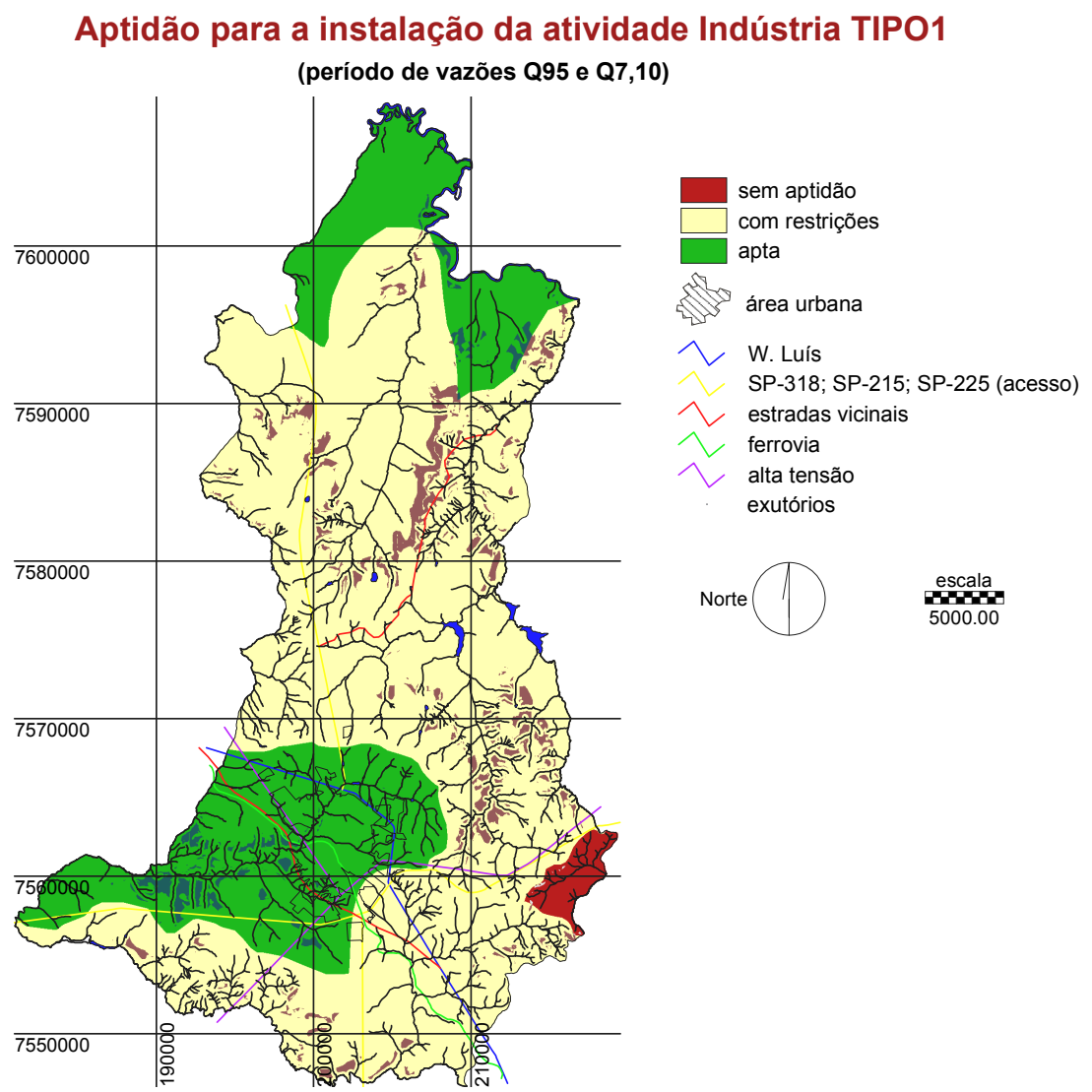

FIGURA 17: Áreas consideradas aptas para a instalação do empreendimento Indústria TIPO 1, associadas às aptidões apresentadas pelas sub-bacias em que se localizam, considerando as vazões $Q_{95}$ e $Q_{7,10}$

Os resultados para a atividade analisada indicam que, para todos os períodos considerados, as vazões encontradas nos exutórios das sub-bacias denominadas Monjolinho, Mogi 1 e Mogi 2, associada ao enquadramento dos respectivos corpos d'água, garantem o atendimento às solicitações desta atividade.

Para os períodos de vazão média (ou superior), a sub-bacia do rio Chibarro (enquadrado como classe 3 ) é classificada como apta para o atendimento às solicitações da atividade, unindo-se às outras áreas mencionadas. Num período de vazão inferior à $Q_{95}$, a sub-bacia denominada Pântano não apresenta aptidão para a instalação da atividade. 


\subsubsection{Indústria do TIPO 2 (suco de laranja)}

A análise sobre a solicitação sobre os recursos hídricos, para esta atividade, resulta nos valores apresentados nas tabelas 22,23 e 24, respectivamente relativas às vazões $Q_{\text {méd }}, Q_{95}$ e $Q_{7,10}$.

TABELA 22 - Classes de aptidão para as sub-bacias consideradas, em função dos valores para as concentrações iniciais de DBO e OD (atividade Indústria do TIPO 2), para o período de vazão $Q_{\text {méd }}$

\begin{tabular}{ccccccc} 
Sub-bacia & $\boldsymbol{Q}_{\text {méd }}(\mathrm{I} / \mathbf{s})$ & $\boldsymbol{L}_{0}(\mathbf{m g} / \mathbf{l})$ & $\boldsymbol{C}_{0}(\mathbf{m g} / \mathbf{l})$ & índice $L_{0}$ & índice $\boldsymbol{C}_{0}$ & $\begin{array}{c}\text { Classe de } \\
\text { aptidão }\end{array}$ \\
\hline Monjolo & 2329 & 2.37 & 6.38 & - & 3.19 & apta \\
Jacaré & 7725 & 1.77 & 6.46 & 2.83 & 1.29 & com restrições \\
Feijão & 2275 & 2.39 & 6.37 & 2.09 & 1.27 & com restrições \\
Quilombo & 6613 & 1.81 & 6.46 & 2.76 & 1.29 & com restrições \\
Araras & 3128 & 2.15 & 6.41 & 2.33 & 1.28 & com restrições \\
Cabaceiras & 2463 & 2.32 & 6.38 & 2.15 & 1.28 & com restrições \\
Chibarro & 712 & 4.22 & 6.11 & 2.37 & 1.53 & apta \\
Pântano & 293 & 7.59 & 5.63 & 0.66 & 1.13 & s/ aptidão \\
\hline
\end{tabular}

TABELA 23 - Classes de aptidão para as sub-bacias consideradas, em função dos valores para as concentrações iniciais de DBO e OD (atividade Indústria do TIPO 2), para o período de vazão $Q_{95}$

\begin{tabular}{ccccccc} 
Sub-bacia & $\mathbf{Q}_{95}(\mathbf{l} / \mathbf{s})$ & $\boldsymbol{L}_{0}(\mathbf{m g} / \mathbf{l})$ & $\boldsymbol{C}_{0}(\mathbf{m g} / \mathbf{l})$ & índice $L_{0}$ & índice $\boldsymbol{C}_{0}$ & $\begin{array}{c}\text { Classe de } \\
\text { aptidão }\end{array}$ \\
\hline Monjolo & 1202 & 3.15 & 6.26 & - & 3.13 & apta \\
Jacaré & 3754 & 2.04 & 6.42 & 2.45 & 1.28 & com restrições \\
Feijão & 1174 & 3.19 & 6.26 & 1.57 & 1.25 & com restrições \\
Quilombo & 2401 & 2.34 & 6.38 & 2.13 & 1.28 & com restrições \\
Araras & 1135 & 3.25 & 6.25 & 1.54 & 1.25 & com restrições \\
Cabaceiras & 894 & 3.69 & 6.19 & 1.35 & 1.24 & com restrições \\
Chibarro & 259 & 8.27 & 5.53 & 1.21 & 1.38 & com restrições \\
Pântano & 106 & 15.12 & 4.55 & 0.33 & 0.91 & s/ aptidão \\
\hline
\end{tabular}


TABELA 24 - Classes de aptidão para as sub-bacias consideradas, em função dos valores para as concentrações iniciais de DBO e OD (atividade Indústria do TIPO 2), para o período de vazão $Q_{7,10}$

\begin{tabular}{ccccccc} 
Sub-bacia & $\boldsymbol{Q}_{7,10}(\mathrm{l} / \mathbf{s})$ & $\boldsymbol{L}_{0}(\mathbf{m g} / \mathbf{l})$ & $\boldsymbol{C}_{0}(\mathbf{m g} / \mathbf{l})$ & índice $L_{0}$ & índice $\boldsymbol{C}_{0}$ & $\begin{array}{c}\text { Classe de } \\
\text { aptidão }\end{array}$ \\
\hline Monjolo & 961 & 3.55 & 6.21 & - & 3.10 & apta \\
Jacaré & 3003 & 2.18 & 6.40 & 2.30 & 1.28 & com restrições \\
Feijão & 939 & 3.59 & 6.20 & 1.39 & 1.24 & com restrições \\
Quilombo & 1609 & 2.75 & 6.32 & 1.82 & 1.26 & com restrições \\
Araras & 761 & 4.06 & 6.13 & 1.23 & 1.23 & com restrições \\
Cabaceiras & 559 & 4.91 & 6.01 & 1.02 & 1.20 & com restrições \\
Chibarro & 173 & 10.94 & 5.15 & 0.91 & 1.29 & s/ aptidão \\
Pântano & 71 & 19.22 & 3.97 & 0.26 & 0.79 & s/ aptidão \\
\hline
\end{tabular}

Novamente percebe-se que, para a atividade analisada, o fator limitante (em função da ponderação adotada) é representado na maioria das vezes pela concentração de OD apresentada pelo efluente a ser lançado, excetuando-se o caso da sub-bacia do rio Chibarro, que para um período de vazão crítica $\left(Q_{7,10}\right)$ foi classificada como "sem aptidão" em função do índice obtido para a DBO da mistura $\left(L_{\circ}\right)$. Para esse mesmo período, nota-se que a sub-bacia do ribeirão das Cabaceiras se apresenta no limite entre as classes de aptidão "com restrições" e "sem aptidão".

Novamente as conclusões referentes à aptidão apresentada pela sub-bacia do rio do Monjolinho se mantêm: a maior permissividade do enquadramento atual do rio do Monjolinho (classe 4) em termos de concentrações admissíveis para a DBO e o OD faz com que esta sub-bacia seja classificada como apta. No caso da atividade avaliada, ainda sobre esse respeito, o mesmo ocorre para a sub-bacia do rio Chibarro (enquadrado atualmente como classe 3 ).

As figuras 18 a 20 apresentam a distribuição das áreas de aptidão máxima e média-alta para a instalação de atividades industriais, de acordo com a metodologia adotada, ao longo das sub-bacias consideradas para o território do município. 


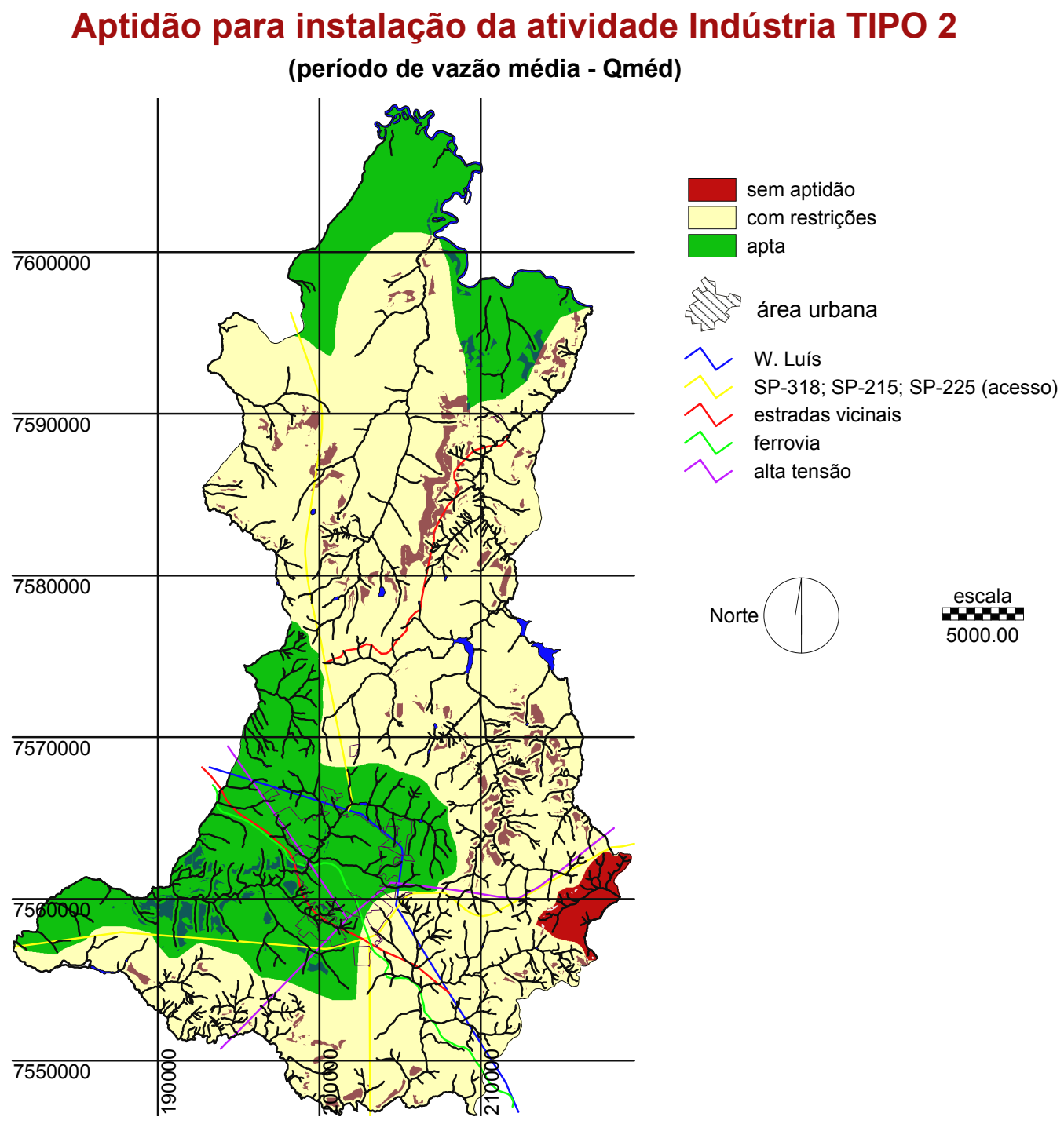

FIGURA 18: Áreas consideradas aptas para a instalação do empreendimento Indústria TIPO 2, associadas às aptidões apresentadas pelas sub-bacias em que se localizam, considerando a vazão $Q_{\text {méd }}$ 


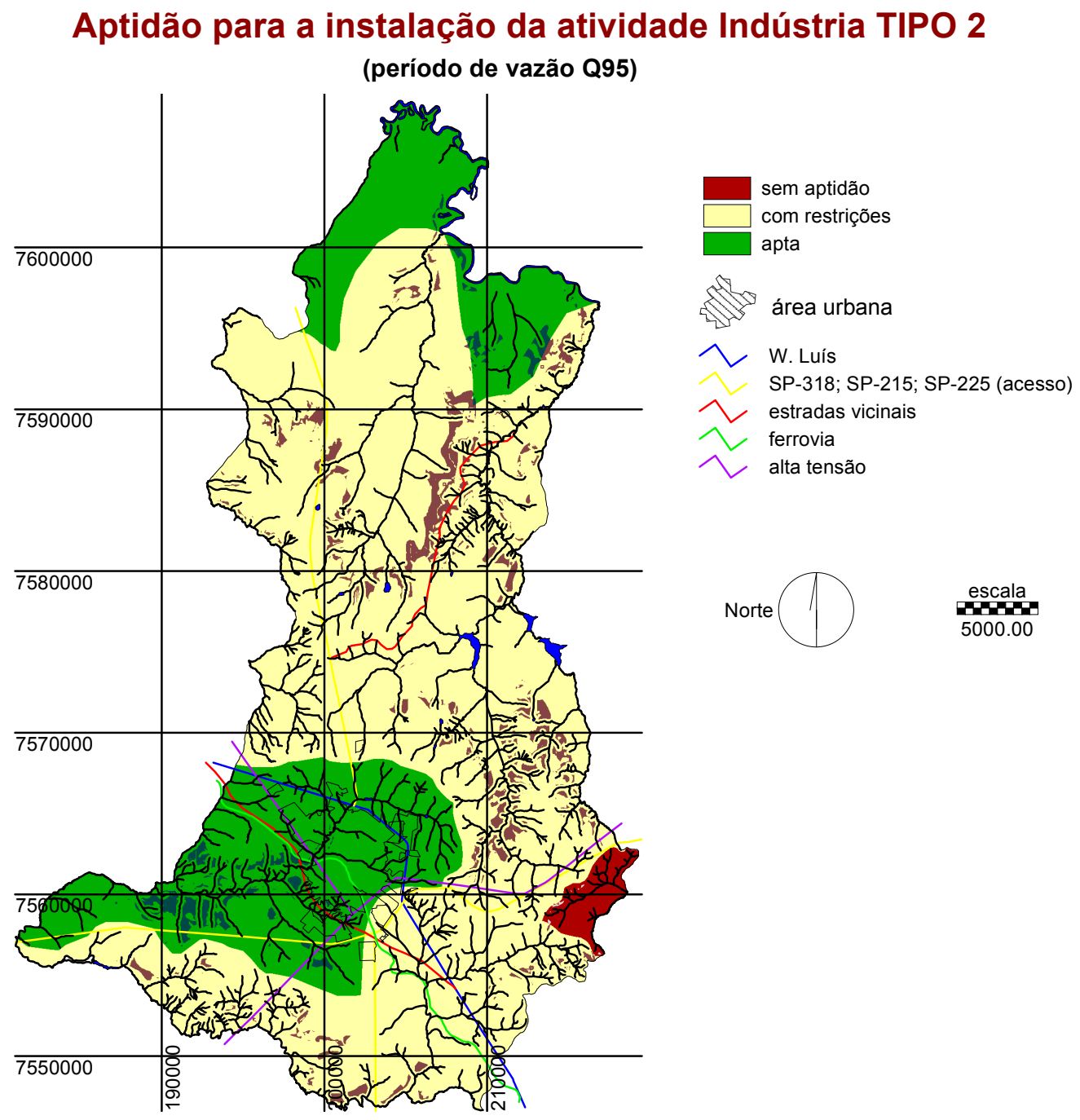

FIGURA 19: Áreas consideradas aptas para a instalação do empreendimento Indústria TIPO 2, associadas às aptidões apresentadas pelas sub-bacias em que se localizam, considerando a vazão $Q_{95}$ 


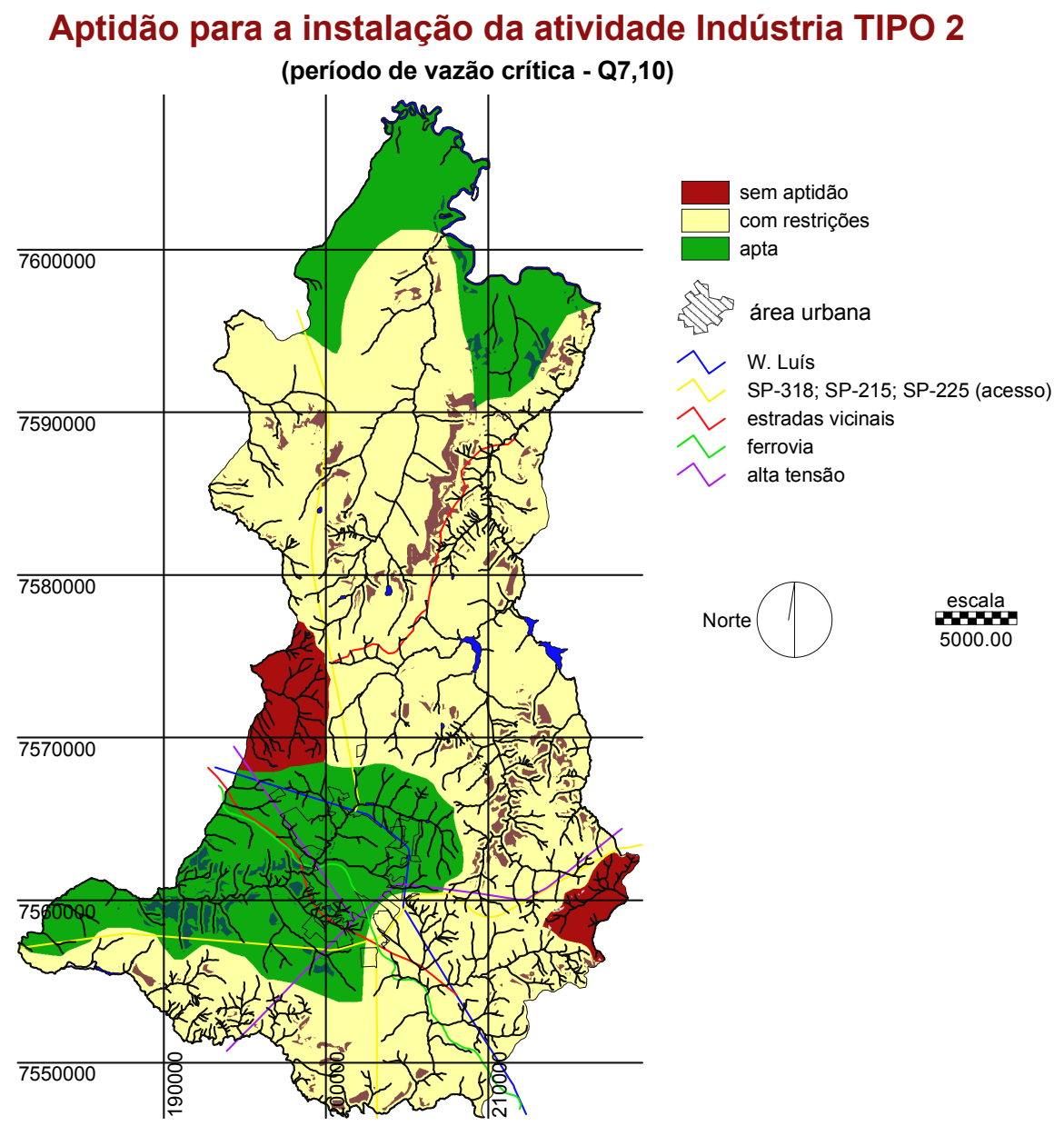

FIGURA 20: Áreas consideradas aptas para a instalação do empreendimento Indústria TIPO 2, associadas às aptidões apresentadas pelas sub-bacias em que se localizam, considerando a vazão $Q_{7,10}$

Percebe-se pelos resultados obtidos que em períodos de regime de vazão superior à média as sub-bacias do Monjolinho e do Chibarro, bem como as sub-bacias denominadas Mogi1 e Mogi 2, apresentam capacidade de atender à solicitação da atividade analisada.

Para os períodos de vazão média (ou superior), a sub-bacia do rio Chibarro (enquadrado como classe 3 ) é classificada como apta para o atendimento às solicitações da atividade, unindo-se às outras áreas mencionadas. Em períodos de vazão próxima à vazão crítica a sub-bacia do rio Chibarro se mostra incompatível com 
a atividade, não apresentando um volume de água suficiente para que suportar o lançamento do efluente resultante da atividade. Ressalta-se que a solicitação sobre os recursos hídricos decorrente da atividade Indústria TIPO 2 é bastante severa: a avaliação efetuada considera a instalação de apenas uma indústria desse tipo, diferente da análise efetuada para a atividade indústria do TIPO 1, quando foi considerada a instalação de um distrito industrial que comportasse 5 indústrias semelhantes.

\subsubsection{Estação de Tratamento de Esgotos (ETE)}

A análise sobre a solicitação sobre os recursos hídricos, para esta atividade, resulta nos valores apresentados nas tabelas 25,26 e 27, respectivamente relativas às vazões $Q_{\text {méd }}, Q_{95}$ e $Q_{7,10}$.

TABELA 25 - Classes de aptidão para as sub-bacias consideradas, em função dos valores para as concentrações iniciais de DBO e OD (atividade ETE), para o período de vazão $Q_{\text {méd }}$

\begin{tabular}{ccccccc} 
Sub-bacia & $\boldsymbol{Q}_{\text {méd }}(\mathrm{I} / \mathbf{s})$ & $\boldsymbol{L}_{0}(\mathbf{m g} / \mathbf{l})$ & $\boldsymbol{C}_{0}(\mathbf{m g} / \mathbf{l})$ & índice $L_{0}$ & índice $\boldsymbol{C}_{0}$ & $\begin{array}{c}\text { Classe de } \\
\text { aptidão }\end{array}$ \\
\hline Monjolo & 2329 & 5.36 & 4.64 & - & 2.32 & apta \\
Jacaré & 7725 & 2.96 & 5.80 & 1.69 & 1.16 & com restrições \\
Feijão & 2275 & 5.43 & 4.61 & 0.92 & 0.92 & s/ aptidão \\
Quilombo & 6613 & 3.17 & 5.70 & 1.58 & 1.14 & com restrições \\
Araras & 3128 & 4.60 & 5.01 & 1.09 & 1.00 & com restrições \\
Cabaceiras & 2463 & 5.21 & 4.71 & 0.96 & 0.94 & s/ aptidão \\
Chibarro & 712 & 9.16 & 2.81 & 1.09 & 0.70 & s/ aptidão \\
Pântano & 293 & 11.78 & 1.55 & 0.42 & 0.31 & s/ aptidão \\
\hline
\end{tabular}


TABELA 26 - Classes de aptidão para as sub-bacias consideradas, em função dos valores para as concentrações iniciais de DBO e OD (atividade ETE), para o período de vazão $Q_{95}$

\begin{tabular}{ccccccc} 
Sub-bacia & $\boldsymbol{Q}_{95}(\mathbf{l} / \mathbf{s})$ & $\boldsymbol{L}_{0}(\mathbf{m g} / \mathbf{l})$ & $\boldsymbol{C}_{0}(\mathbf{m g} / \mathbf{l})$ & índice $L_{0}$ & índice $\boldsymbol{C}_{0}$ & $\begin{array}{c}\text { Classe de } \\
\text { aptidão }\end{array}$ \\
\hline Monjolo & 1202 & 7.40 & 3.66 & - & 1.83 & apta \\
Jacaré & 3754 & 4.19 & 5.20 & 1.19 & 1.04 & com restrições \\
Feijão & 1174 & 7.48 & 3.62 & 0.67 & 0.72 & s/ aptidão \\
Quilombo & 2401 & 5.28 & 4.68 & 0.95 & 0.94 & s/ aptidão \\
Araras & 1135 & 7.59 & 3.57 & 0.66 & 0.71 & s/ aptidão \\
Cabaceiras & 894 & 8.40 & 3.18 & 0.60 & 0.64 & s/ aptidão \\
Chibarro & 259 & 12.07 & 1.41 & 0.83 & 0.35 & s/ aptidão \\
Pântano & 106 & 13.62 & 0.66 & 0.37 & 0.13 & s/ aptidão \\
\hline
\end{tabular}

TABELA 27 - Classes de aptidão para as sub-bacias consideradas, em função dos valores para as concentrações iniciais de DBO e OD (atividade ETE), para o período de vazão $Q_{7,10}$

\begin{tabular}{ccccccc} 
Sub-bacia & $\boldsymbol{Q}_{7,10}(\mathrm{I} / \mathbf{s})$ & $\boldsymbol{L}_{0}(\mathbf{m g} / \mathbf{l})$ & $\boldsymbol{C}_{0}(\mathbf{m g} / \mathbf{l})$ & índice $L_{0}$ & índice $\boldsymbol{C}_{0}$ & $\begin{array}{c}\text { Classe de } \\
\text { aptidão }\end{array}$ \\
\hline Monjolo & 961 & 8.15 & 3.30 & - & 1.65 & apta \\
Jacaré & 3003 & 4.70 & 4.96 & 1.06 & 0.99 & s/ aptidão \\
Feijão & 939 & 8.23 & 3.26 & 0.61 & 0.65 & s/ aptidão \\
Quilombo & 1609 & 6.46 & 4.11 & 0.77 & 0.82 & s/ aptidão \\
Araras & 761 & 8.94 & 2.92 & 0.56 & 0.58 & s/ aptidão \\
Cabaceiras & 559 & 9.95 & 2.43 & 0.50 & 0.49 & s/ aptidão \\
Chibarro & 173 & 12.89 & 1.02 & 0.78 & 0.25 & s/ aptidão \\
Pântano & 71 & 14.05 & 0.46 & 0.36 & 0.09 & s/ aptidão \\
\hline
\end{tabular}

Neste caso, percebe-se que a instalação de uma única estação de tratamento que atenda a todo o município, durante os períodos considerados, só é possível de ser efetuada na sub-bacia do rio do Monjolinho (lançando o efluente da estação no exutório da sub-bacia), essencialmente devido ao enquadramento deste corpo d'água, e nas sub-bacias denominadas Mogi 1 e Mogi 2, devido ao volume de água proveniente do rio Mogi-Guaçu. 
Para os períodos de vazão superior à vazão média apresentada pelos corpos d'água, existe a possibilidade de se instalar a ETE nas sub-bacias dos rios Jacaré, Quilombo e córrego das Araras, desde que observadas algumas medidas de contenção do lançamento durante os períodos nos quais a vazão se apresente inferior ao valor médio.

As figuras 21 a 23 ilustram as considerações apresentadas para esta atividade, mostrando a distribuição das áreas de aptidão máxima e média-alta para a instalação de atividades industriais, de acordo com a metodologia adotada, combinada às aptidões apresentadas pelas sub-bacias consideradas.

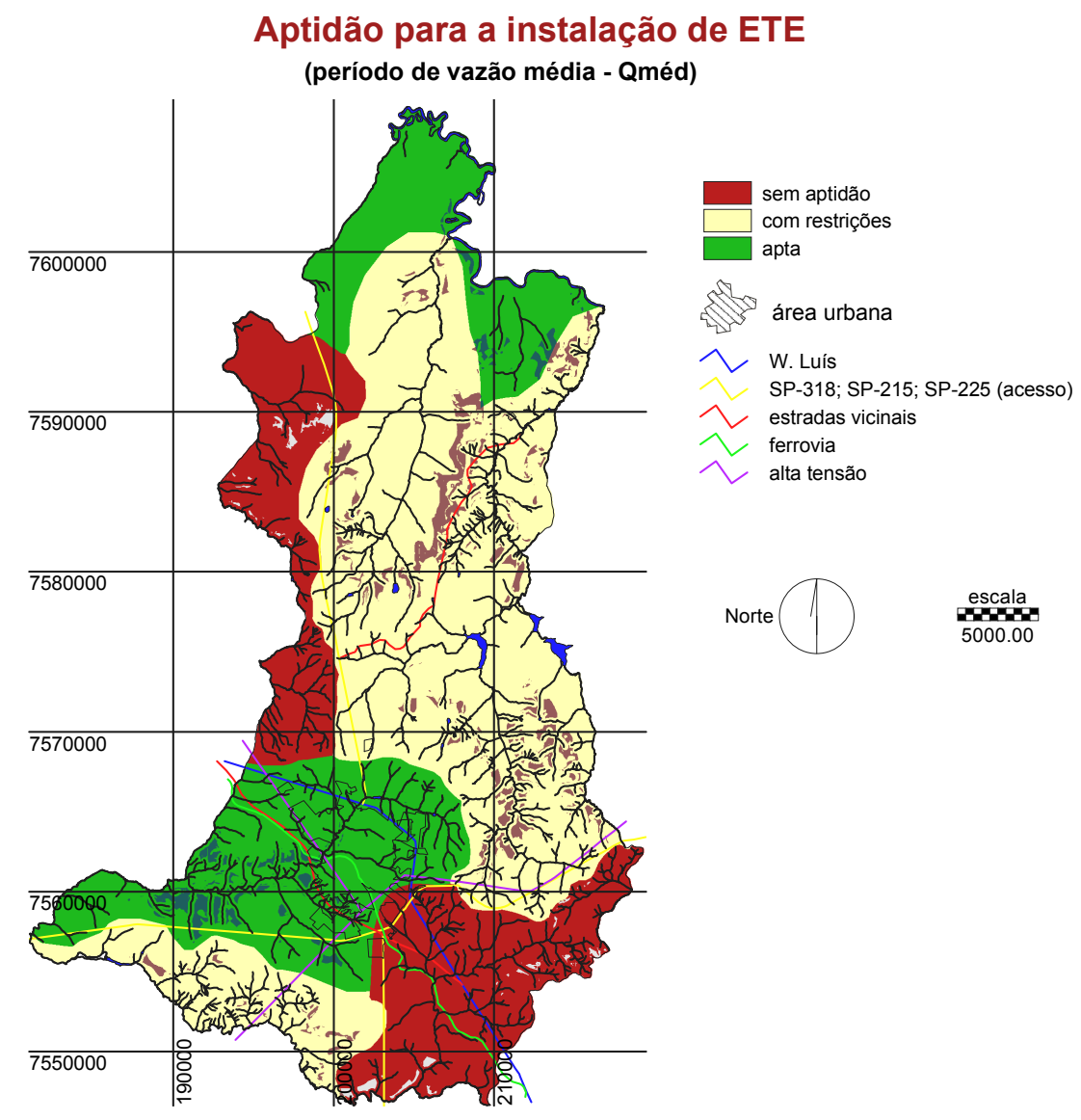

FIGURA 21: Áreas consideradas aptas para a instalação do empreendimento Estação de Tratamento de Esgotos, associadas às aptidões apresentadas pelas sub-bacias em que se localizam, considerando a vazão $Q_{\text {méd }}$ 


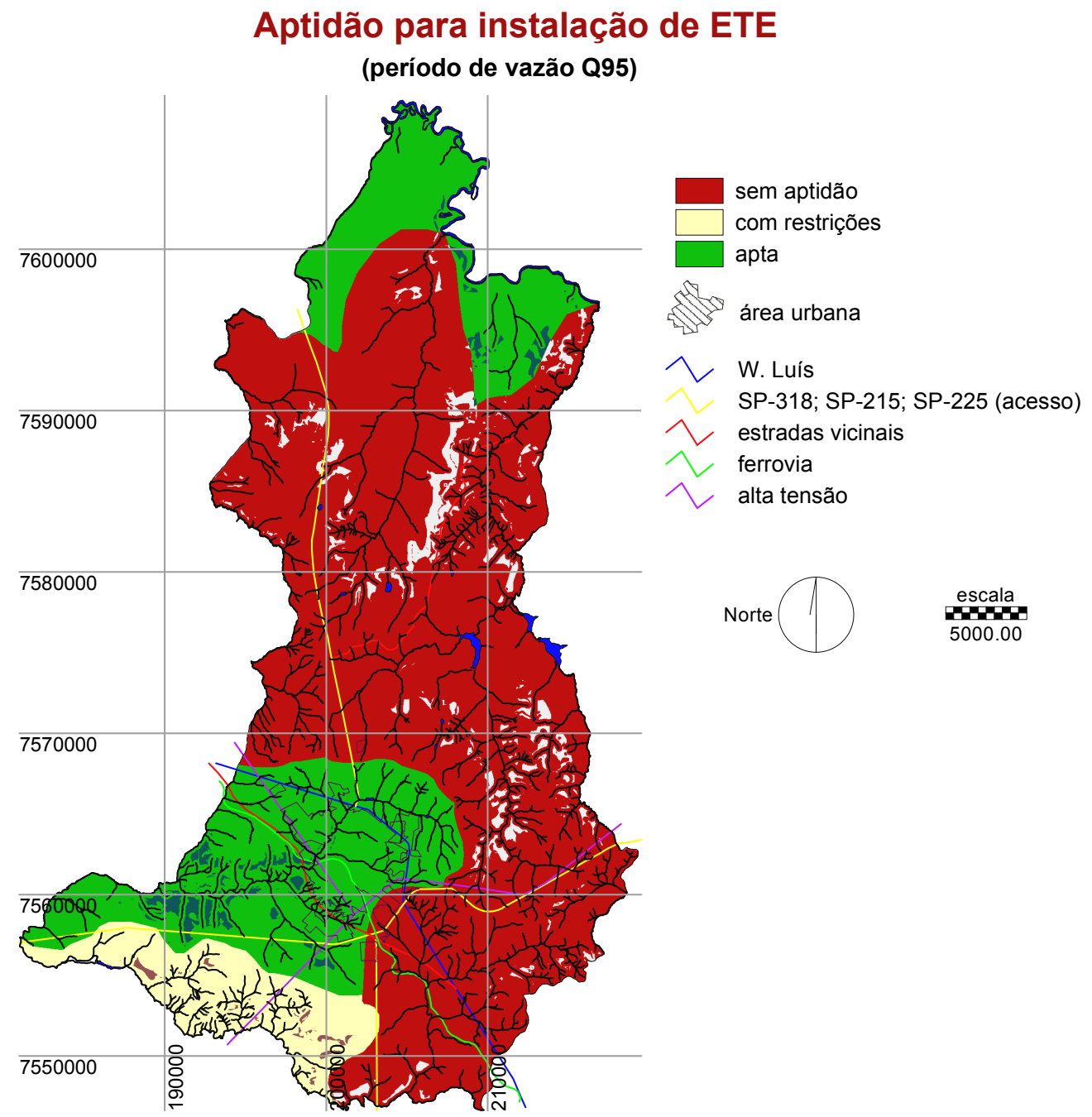

FIGURA 22: Áreas consideradas aptas para a instalação do empreendimento Estação de Tratamento de Esgotos, associadas às aptidões apresentadas pelas sub-bacias em que se localizam, considerando a vazão $Q_{95}$

Observando os resultados apresentados fica claro, por exemplo, que existe a necessidade de se considerar alternativas tecnológicas que possibilitem a instalação de uma ETE no município de São Carlos, quer seja procurando-se aumentar a eficiência do tratamento empregado diminuindo dessa forma a carga a ser lançada), ou introduzindo novas etapas no tratamento (reoxigenação do efluente, por exemplo). 


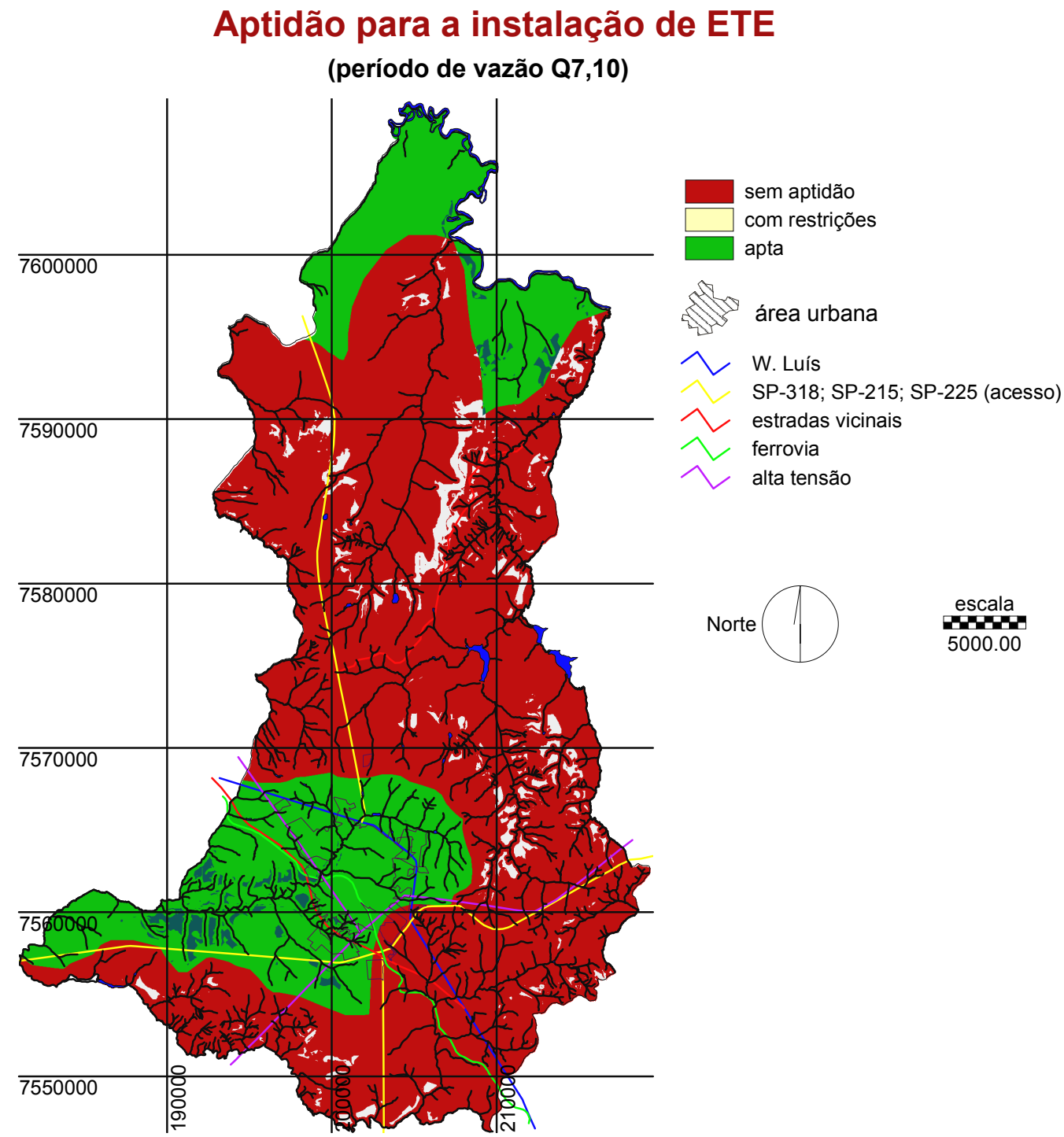

FIGURA 23: Áreas consideradas aptas para a instalação do empreendimento Estação de Tratamento de Esgotos, associadas às aptidões apresentadas pelas sub-bacias em que se localizam, considerando a vazão $Q_{7,10}$

\subsubsection{Captação de água para abastecimento}

A partir das considerações apresentadas no item 4.4.4.2.4, relativo à captação de água para o abastecimento do município, a análise sobre a solicitação sobre os recursos hídricos resulta nos valores apresentados nas tabelas 28 e 29, 
respectivamente relativas às vazões $Q_{\text {méd }}, Q_{95}$, considerando que a demanda exercida pela atividade (470 l/s) não pode provocar uma vazão inferior à $Q_{7,10}$.

TABELA 28 - Classes de aptidão para as sub-bacias consideradas, em função do índice para a oferta, obtido para o período de vazão $Q_{\text {méd }}$

\begin{tabular}{cccccc} 
Sub-bacia & $\boldsymbol{Q}_{\text {méd }}(\mathbf{I} / \mathbf{s})$ & $\boldsymbol{Q}_{\mathbf{7 , 1 0}}(\mathbf{I} / \mathbf{s})$ & oferta $(\mathbf{I} / \mathbf{s})$ & $\begin{array}{c}\text { índice oferta } \\
\left(\mathbf{Q}_{\text {méd }}\right)\end{array}$ & $\begin{array}{c}\text { Classe de } \\
\text { aptidão }\end{array}$ \\
\hline Monjolo & 2329 & 961 & 1368 & 2.91 & apta \\
Jacaré & 7725 & 3003 & 4722 & 10.05 & apta \\
Feijão & 2275 & 939 & 1336 & 2.84 & apta \\
Quilombo & 6613 & 1609 & 5004 & 10.65 & apta \\
Araras & 3128 & 761 & 2367 & 5.04 & apta \\
Cabaceiras & 2463 & 559 & 1904 & 4.05 & apta \\
Chibarro & 712 & 173 & 539 & 1.15 & c/ restrições \\
Pântano & 293 & 71 & 222 & 0.47 & s/ aptidão \\
\hline
\end{tabular}

TABELA 29 - Classes de aptidão para as sub-bacias consideradas, em função do índice para a oferta, obtido para o período de vazão $Q_{95}$

\begin{tabular}{cccccc} 
Sub-bacia & $\boldsymbol{Q}_{95}(\mathrm{I} / \mathbf{s})$ & $\boldsymbol{Q}_{\mathbf{7 , 1 0}}(\mathrm{I} / \mathbf{s})$ & oferta (I/s) & $\begin{array}{c}\text { índice oferta } \\
\left(\mathbf{Q}_{\text {méd }}\right)\end{array}$ & $\begin{array}{c}\text { Classe de } \\
\text { aptidão }\end{array}$ \\
\hline Monjolo & 1202 & 961 & 241 & 0.51 & s/ aptidão \\
Jacaré & 3754 & 3003 & 751 & 1.60 & apta \\
Feijão & 1174 & 939 & 235 & 0.50 & s/ aptidão \\
Quilombo & 2401 & 1609 & 792 & 1.69 & apta \\
Araras & 1135 & 761 & 374 & 0.80 & s/ aptidão \\
Cabaceiras & 894 & 559 & 335 & 0.71 & s/ aptidão \\
Chibarro & 259 & 173 & 86 & 0.18 & s/ aptidão \\
Pântano & 106 & 71 & 35 & 0.07 & s/ aptidão \\
\hline
\end{tabular}

As informações obtidas revelam que, de acordo com a metodologia empregada, apenas a sub-bacia do Pântano não teria condições de prover a água necessária para o abastecimento do município, em situações de vazão igual ou superior à vazão média, desde que o volume a ser captado seja regularizado. Cabe destacar que a sub-bacia do Chibarro apresenta um índice para a oferta que a coloca num limiar entre a capacidade de atendimento e a impossibilidade de prover a água necessária para o desenvolvimento da atividade. O fato de apresentar restrições num período de vazão 
média não significa necessariamente que a captação de água para abastecimento não poderá ser realizada, mas que existem períodos ao longo do ano nos quais deverá ser efetuada uma gestão adequada em relação à demanda sobre esta sub-bacia.

Num outro extremo, em situações de vazão igual ou inferior à vazão $Q_{95}$, as subbacias do Jacaré e do Quilombo e, obviamente, as sub-bacias Mogi 1 e Mogi 2 teriam condições de fornecer a quantidade necessária sem maiores conseqüências. As figuras 24 e 25 ilustram a situação descrita.

Aptidão para captação de água para abastecimento (período de vazão média - Qméd)

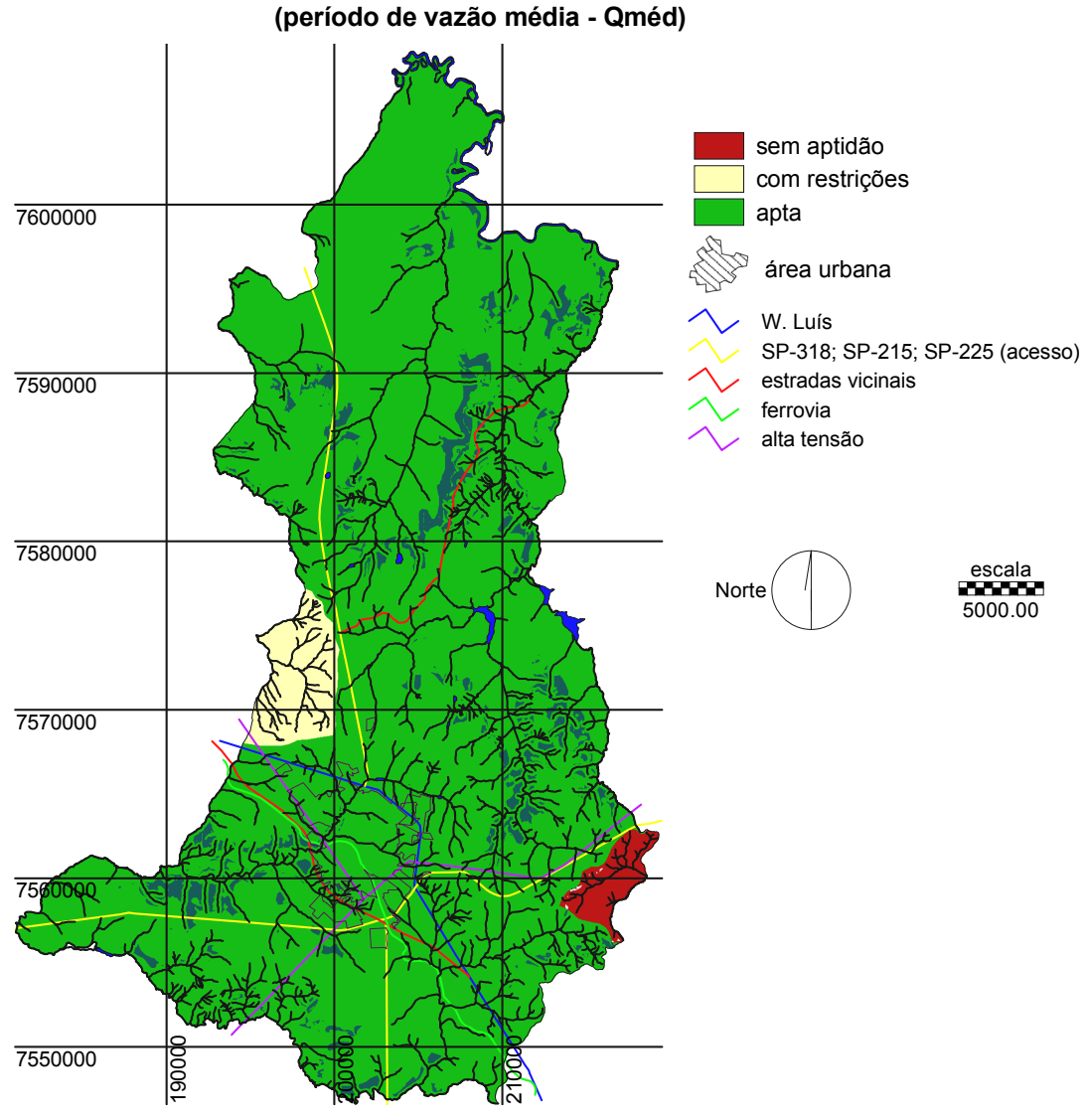

FIGURA 24: Áreas aptas p/ instalação de empreendimentos sobre aptidão para captação de água para abastecimento, para a vazão $Q_{\text {méd }}$ 
Aptidão para captação de água para abastecimento (período de vazão Q95)

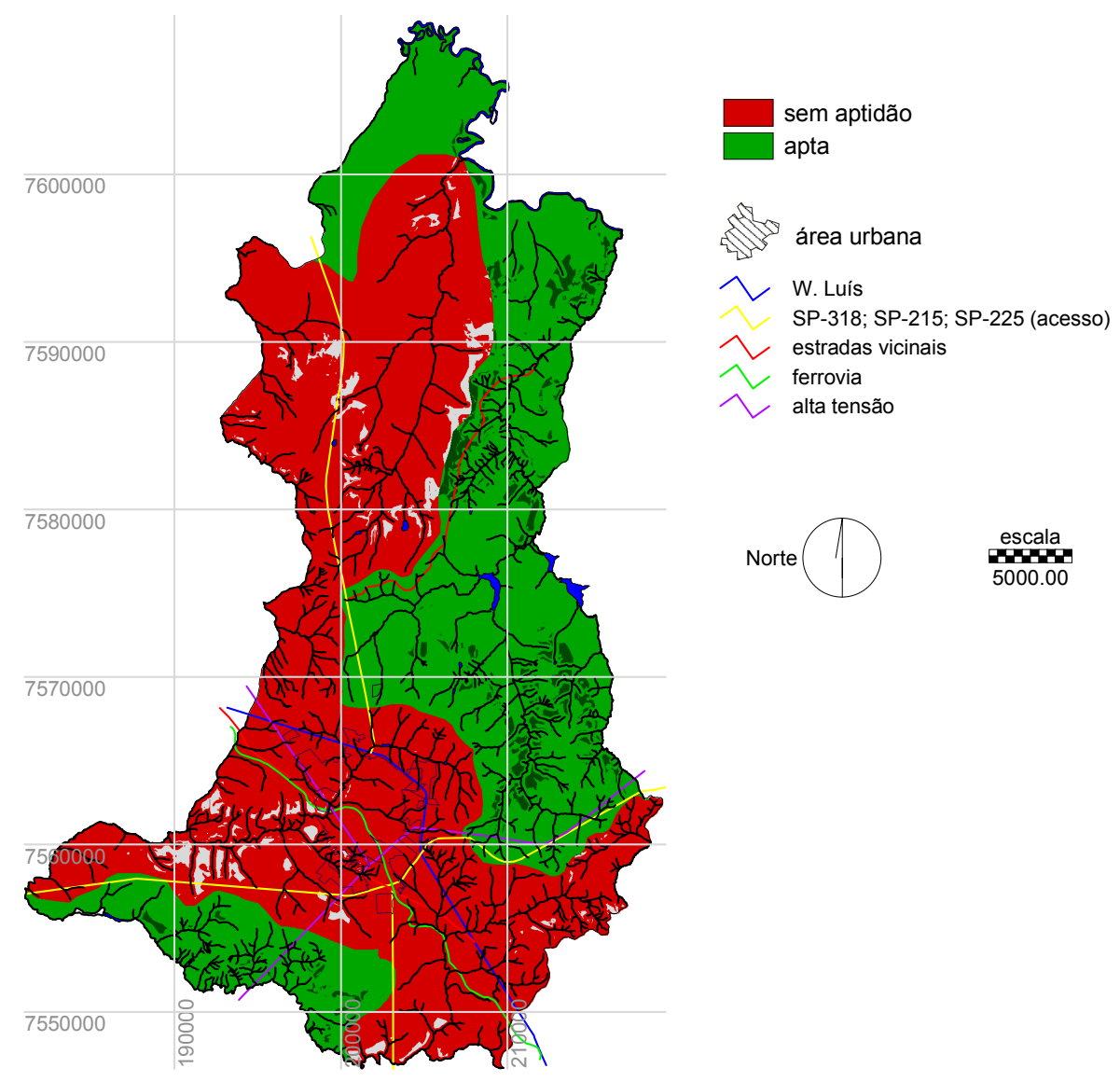

FIGURA 25: Áreas aptas p/ instalação de empreendimentos sobre aptidão para captação de água para abastecimento, para a vazão $Q_{95}$

De forma a compreender as diferentes aptidões apresentadas pelo território do município, em função das diferentes vazões consideradas e das diferentes atividades, a tabela 30 apresenta o conjunto de resultados obtidos: 
TABELA 30 - Síntese das aptidões apresentadas pelo território do município frente às diferentes situações consideradas

\begin{tabular}{|c|c|c|c|c|c|c|c|c|c|c|c|}
\hline \multirow{2}{*}{ Sub-bacia } & \multicolumn{3}{|c|}{ indústria TIPO 1} & \multicolumn{3}{|c|}{ indústria TIPO 2} & \multicolumn{3}{|c|}{ ETE } & \multicolumn{2}{|c|}{ captação } \\
\hline & $Q_{\text {méd }}$ & $Q_{95}$ & $Q_{7,10}$ & $Q_{\text {méd }}$ & $Q_{95}$ & $Q_{7,10}$ & $Q_{\text {méd }}$ & $Q_{95}$ & $Q_{7,10}$ & $\mathbf{Q}_{\text {méd }}$ & $Q_{95}$ \\
\hline Monjolinho & $a$ & $a$ & $a$ & $a$ & $a$ & $a$ & $a$ & $a$ & $a$ & $a$ & $\mathrm{~s}$ \\
\hline Jacaré & $r$ & $r$ & $r$ & $r$ & $r$ & $r$ & $r$ & $r$ & $\mathrm{~s}$ & a & a \\
\hline Feijão & $r$ & $r$ & $r$ & $r$ & $r$ & $r$ & $\mathrm{~s}$ & $\mathrm{~s}$ & $\mathrm{~s}$ & a & $\mathrm{s}$ \\
\hline Quilombo & $r$ & $r$ & $r$ & $r$ & $r$ & $r$ & $r$ & s & s & a & a \\
\hline Araras & $r$ & $r$ & $r$ & $r$ & $r$ & $r$ & $r$ & $\mathrm{~s}$ & $\mathrm{~s}$ & a & $\mathrm{s}$ \\
\hline Cabaceiras & $r$ & $r$ & $r$ & $r$ & $r$ & $r$ & $s$ & $\mathrm{~s}$ & $s$ & a & $s$ \\
\hline Chibarro & a & $r$ & $r$ & a & $r$ & $\mathrm{~s}$ & $\mathrm{~s}$ & $\mathrm{~s}$ & $\mathrm{~s}$ & $r$ & $\mathrm{~s}$ \\
\hline Pântano & $r$ & $\mathrm{~s}$ & $\mathrm{~s}$ & $\mathrm{~s}$ & $\mathrm{~s}$ & $\mathrm{~s}$ & $\mathrm{~s}$ & $\mathrm{~s}$ & $\mathrm{~s}$ & $\mathrm{~s}$ & $\mathrm{~s}$ \\
\hline Mogi 1 & a & a & a & a & a & a & a & a & a & a & a \\
\hline Mogi 2 & $a$ & a & a & a & a & a & $\mathrm{a}$ & a & a & a & $a$ \\
\hline
\end{tabular}




\section{CONCLUSÕES}

A respeito das informações obtidas a partir do emprego da metodologia adotada, observa-se que o território do município de São Carlos, apesar de possuir uma rede de drenagem relativamente abundante, apresenta algumas limitações relacionadas ao atendimento a uma eventual demanda sobre os recursos hídricos, em termos de capacidade de diluição de efluentes e de fornecimento de água para o abastecimento público. Por esse motivo, é necessário o estabelecimento de políticas que orientem a ocupação do território considerando-se a capacidade apresentada pelo meio ambiente de suportar as solicitações advindas da implantação de empreendimentos.

Sendo assim, é fundamental que sejam produzidas informações que atuem como subsídio para que o poder público, em conjunto com a sociedade, possa incorporar a questão ambiental no momento da tomada de decisões, considerando-a como parte integrante do processo decisório. A elaboração de um zoneamento ambiental, a partir de análises semelhantes às efetuadas pelo presente trabalho, vem atuar nesse sentido, uma vez que possibilita de forma bastante clara a visualização das regiões mais adequadas para o recebimento de certas atividades.

Pode-se afirmar, portanto, que o presente trabalho cumpre com sua proposta inicial, observadas as escalas em que as informações primárias foram geradas originalmente, e as incertezas associadas às informações produzidas. Dessa maneira, as informações geradas não devem ser utilizadas para implantação real de empreendimentos na área de estudo, servindo apenas como um indicativo das aptidões e vulnerabilidades apresentadas.

A determinação das aptidões e vulnerabilidades apresentadas nos mapas de suscetibilidade à erosão, risco de assoreamento dos corpos d'água, risco de contaminação de águas subterrâneas e aptidão para a implantação de 
empreendimentos industriais, elaboradas a partir da adaptação de algumas metodologias encontradas na literatura, possibilitam traçar um panorama acerca da situação encontrada, em termos do conjunto de fatores ambientais considerados, relativa à prevenção de impactos e manutenção da qualidade dos recursos hídricos.

A metodologia apresentada para a determinação da aptidão para o atendimento às solicitações sobre os recursos hídricos, provenientes das atividades consideradas, mostra-se compatível com os objetivos do trabalho, ressaltando-se a necessidade de um refinamento nas informações e um detalhamento maior que permita estimar as vazões por trechos dos corpos d'água, de acordo com a necessidade. Isso poderia ser feito subdividindo-se o território do município em bacias menores, de modo a obter-se uma gama de informações mais detalhada.

O ideal, sem dúvida, seria que houvesse o estabelecimento de uma rede de monitoramento para todo o território do município, que possibilitasse uma maior confiabilidade em relação aos parâmetros adotados, especialmente os referentes às vazões estimadas e às concentrações de outros parâmetros, além de DBO e OD, encontradas ao longo dos corpos d'água.

Por fim, é possível perceber a necessidade de se incluir os recursos hídricos como um fator ambiental a ser considerado no momento do estabelecimento de políticas de desenvolvimento para o território. O presente trabalho mostra, de maneira bastante clara, que existem situações nas quais uma ponderação sobre os fatores ambientais que não considere a capacidade de atendimento, apresentada pelos recursos hídricos, às eventuais solicitações provenientes de certas atividades (usuárias do recurso) não é suficiente para que se garanta a viabilidade ambiental dos empreendimentos em questão. Isso se deve ao fato de que certas áreas indicadas como aptas para o recebimento da atividade podem não oferecer condições, em se tratando do fornecimento de água para o abastecimento da atividade ou para a diluição de seus efluentes, que possibilitem um relacionamento satisfatório entre a atividade e o meio em que esta se desenvolve.

O município de São Carlos apresenta uma escassez relativa de água, considerando o atendimento ao abastecimento público e a capacidade de diluição de 
efluentes domésticos, que num raciocínio extremo chegaria até mesmo a limitar o tamanho da população que seria admissível.

Soluções técnicas e tecnológicas existem e sempre existirão, que demandam investimentos vultosos, o que muitas vezes inviabiliza sua aplicação. A opção seria além do caminho óbvio de reduzir o desperdício - rever o estilo de desenvolvimento adotado, inclusive em nível regional, de modo a orientar o tipo de atividade a ser instalada e, ainda, incrementar novas práticas de consumo doméstico, procurando-se minimizar a quantidade de água consumida. 


\section{ANEXO A}

MAPAS BÁSICOS 


\section{TOPOGRAFIA}

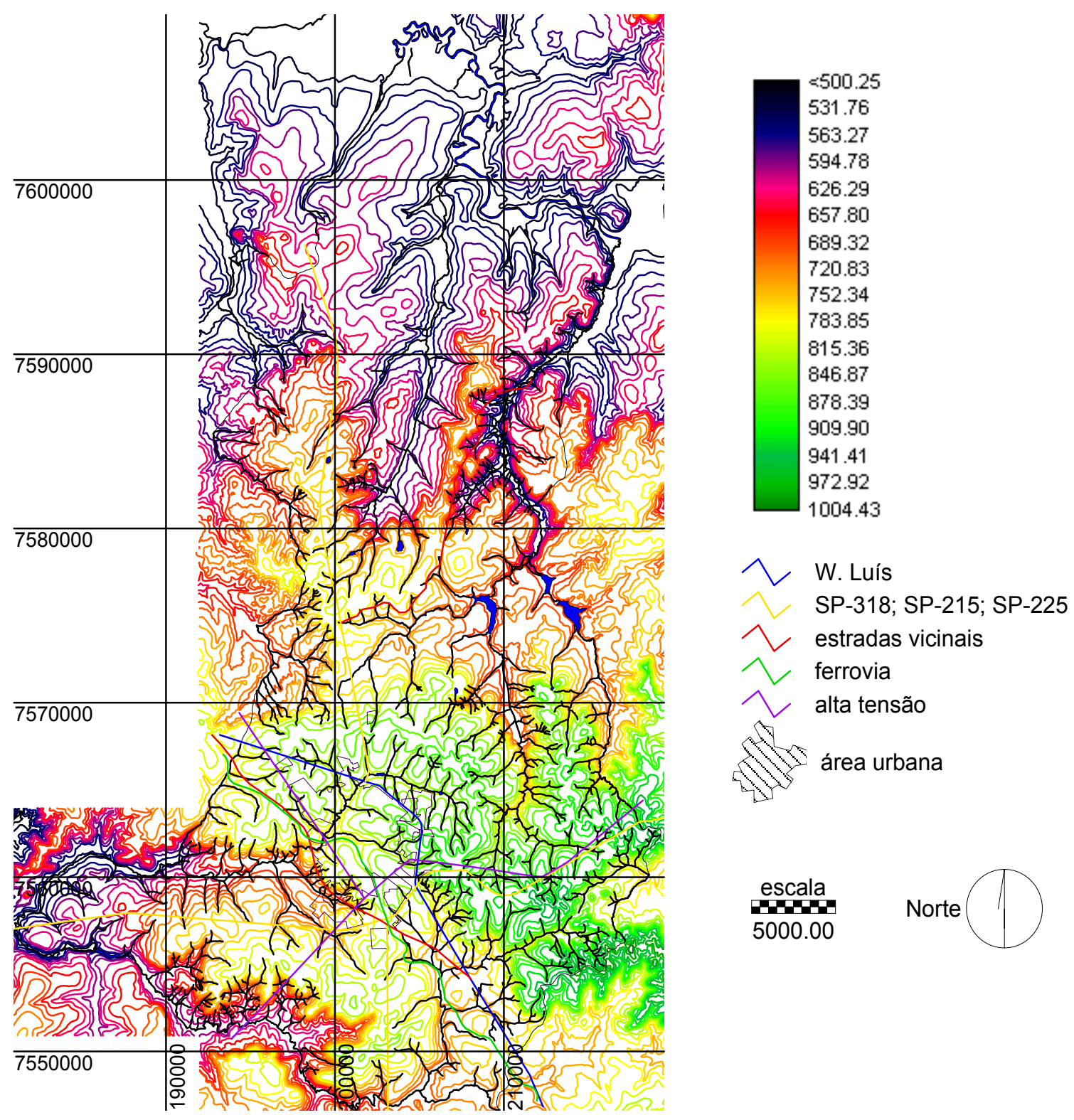

ANEXO A.1. MAPA DE TOPOGRAFIA (IBGE, 1:50.000) 


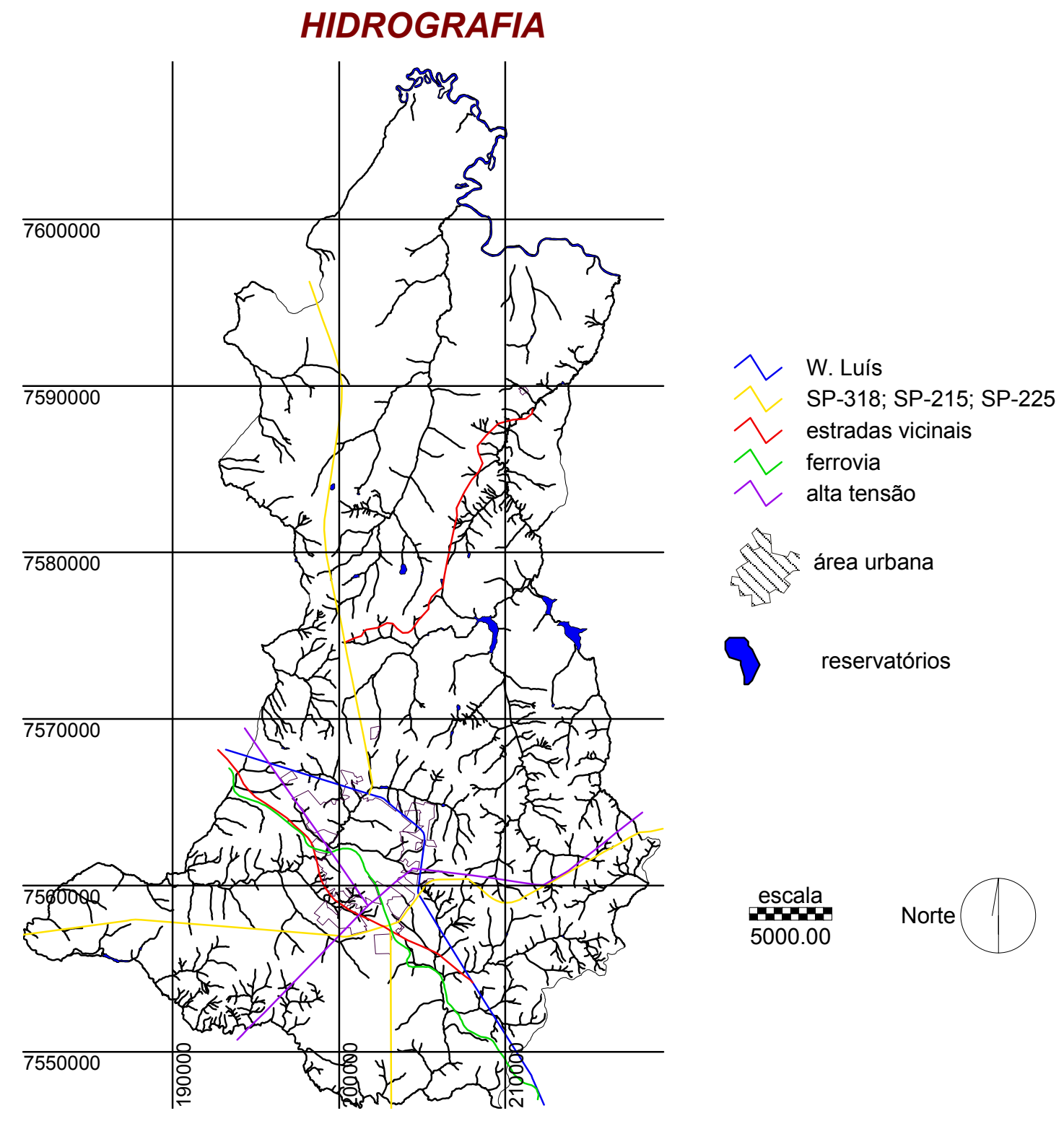

ANEXO A.2. - RIOS, CÓRREGOS E RESERVATÓRIOS (IBGE, 1:50.000) 


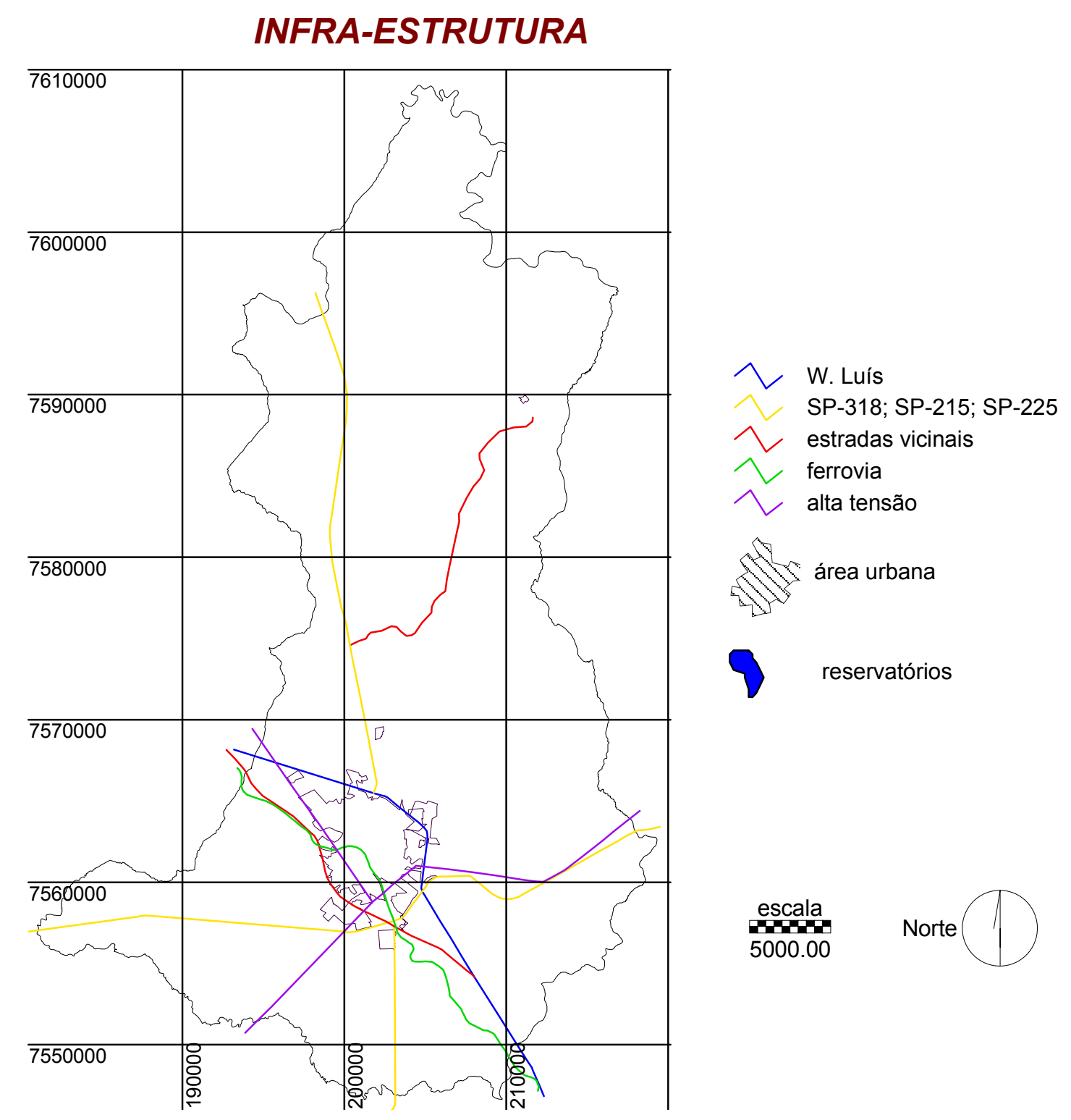

ANEXO A.3. INFRA-ESTRUTURA (malha rodoviária, rede de alta tensão e ferrovia) (IBGE, 1:50.000) 


\section{PEDOLOGIA}

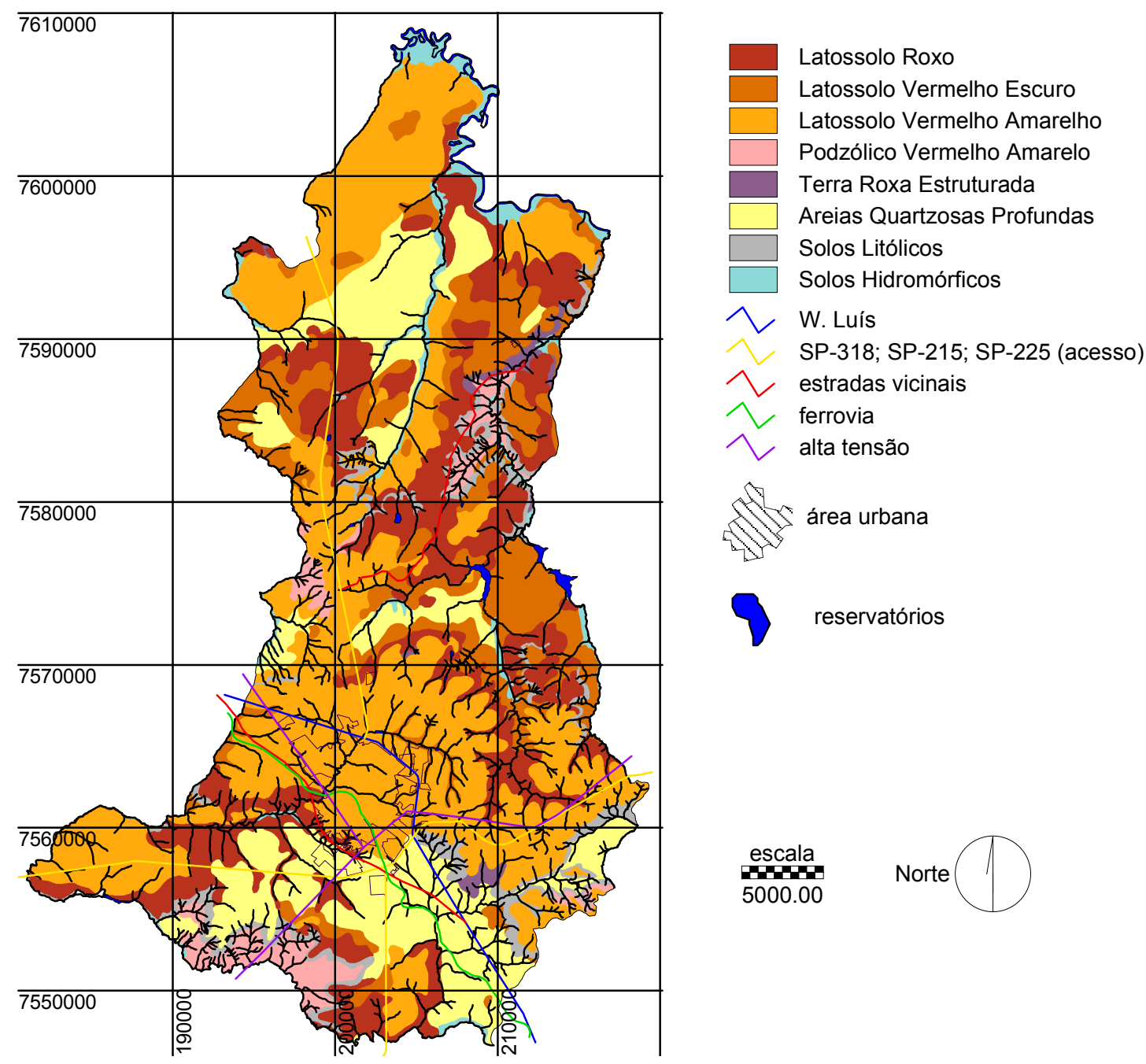

ANEXO A.4. PEDOLOGIA (IAC, 1:100.000) 


\section{GEOLOGIA}

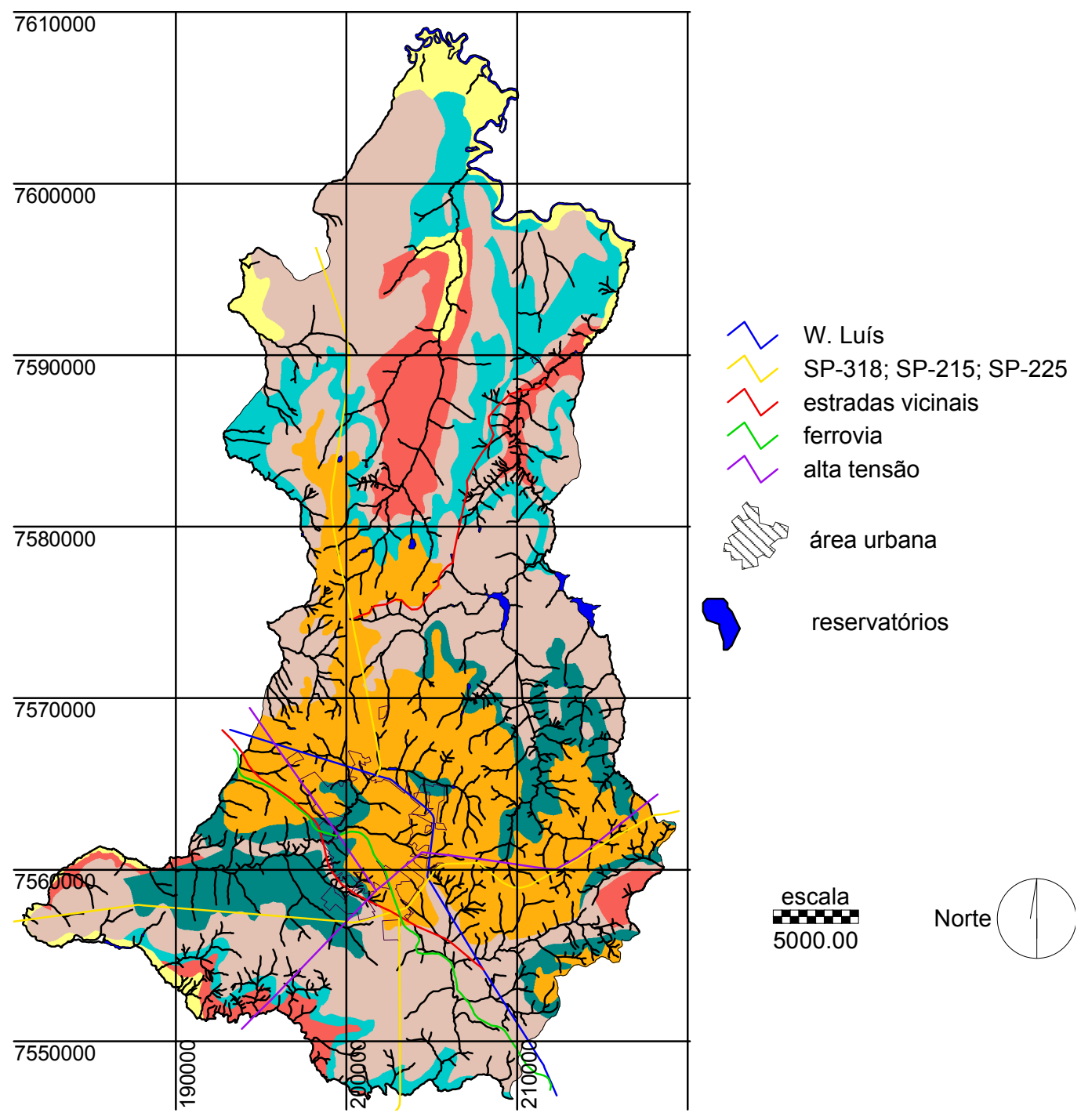

Formação Serra Geral

Depósitos de cimeira - cobertura da Serra de São Carlos

Formação Botucatu

Formação Pirambóia

depósitos aluviais

magmatitos básicos

ANEXO A.5. GEOLOGIA (DAEE, 1:250.000) 


\section{REMANESCENTES DE VEGETAÇÃO}

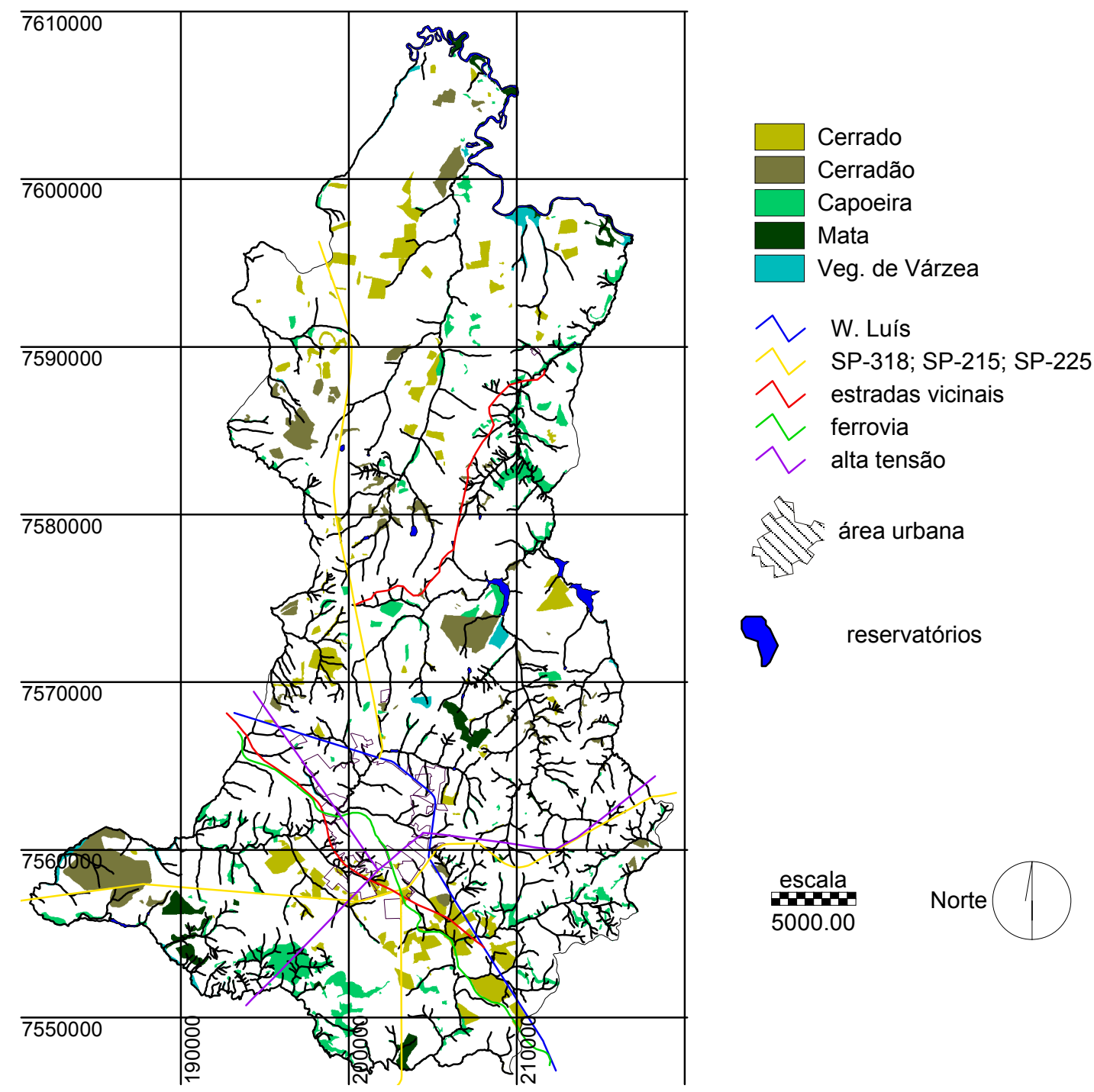

ANEXO A.6. REMANESCENTES DE VEGETAÇÃO (DPRN, 1:50.000) 
ANEXO B

PLANOS INTERMEDIÁRIOS DE INFORMAÇÃO 


\section{MODELO DIGITAL DE ELEVAÇÃO}

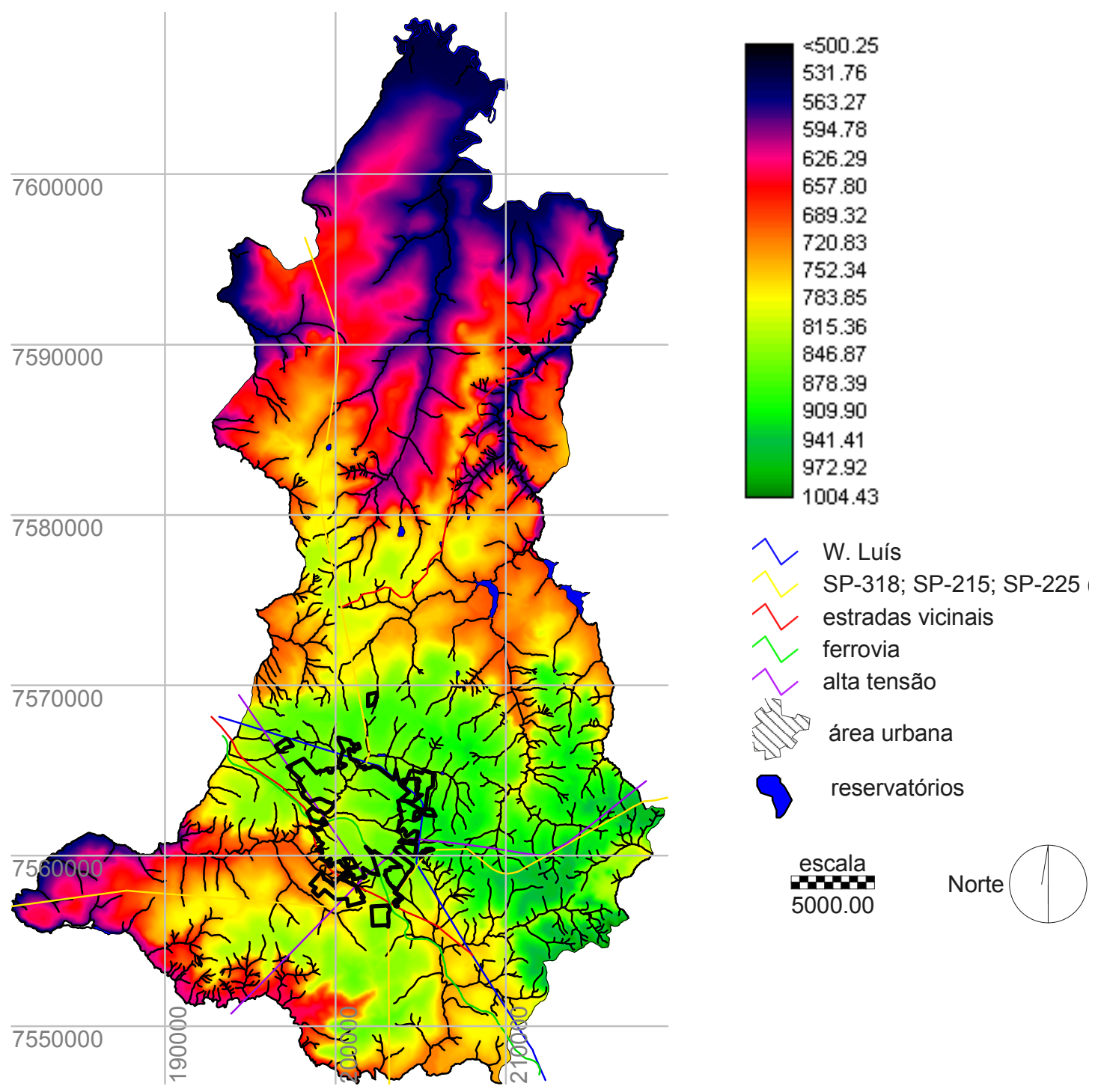

ANEXO B.1. MODELO DIGITAL DE ELEVAÇÃO 


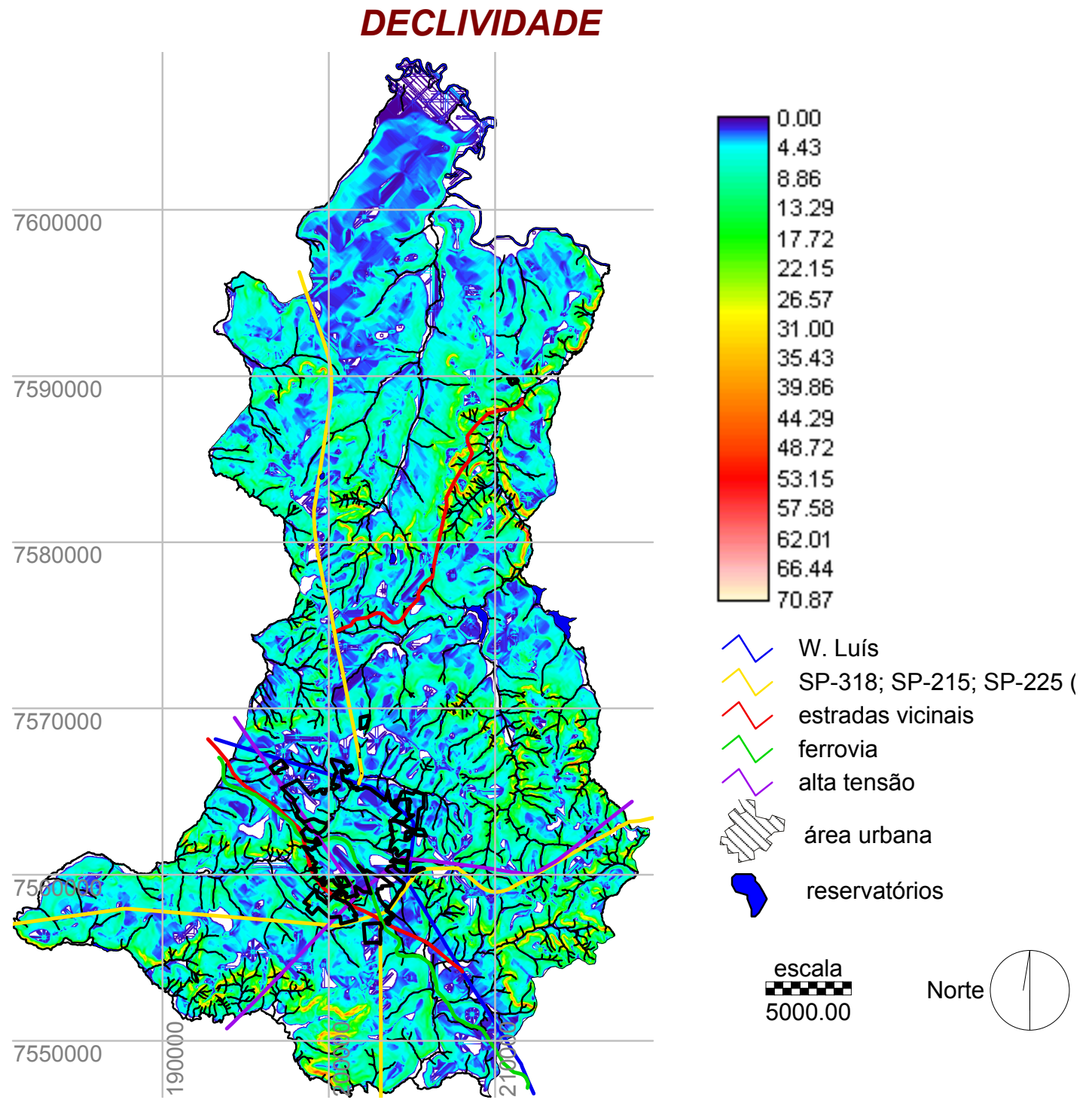

ANEXO B.2. DECLIVIDADE DO TERRENO 


\section{ÁREAS DE PRESERVAÇÃO PERMANENTE} (entorno de rios, reservatórios e nascentes)

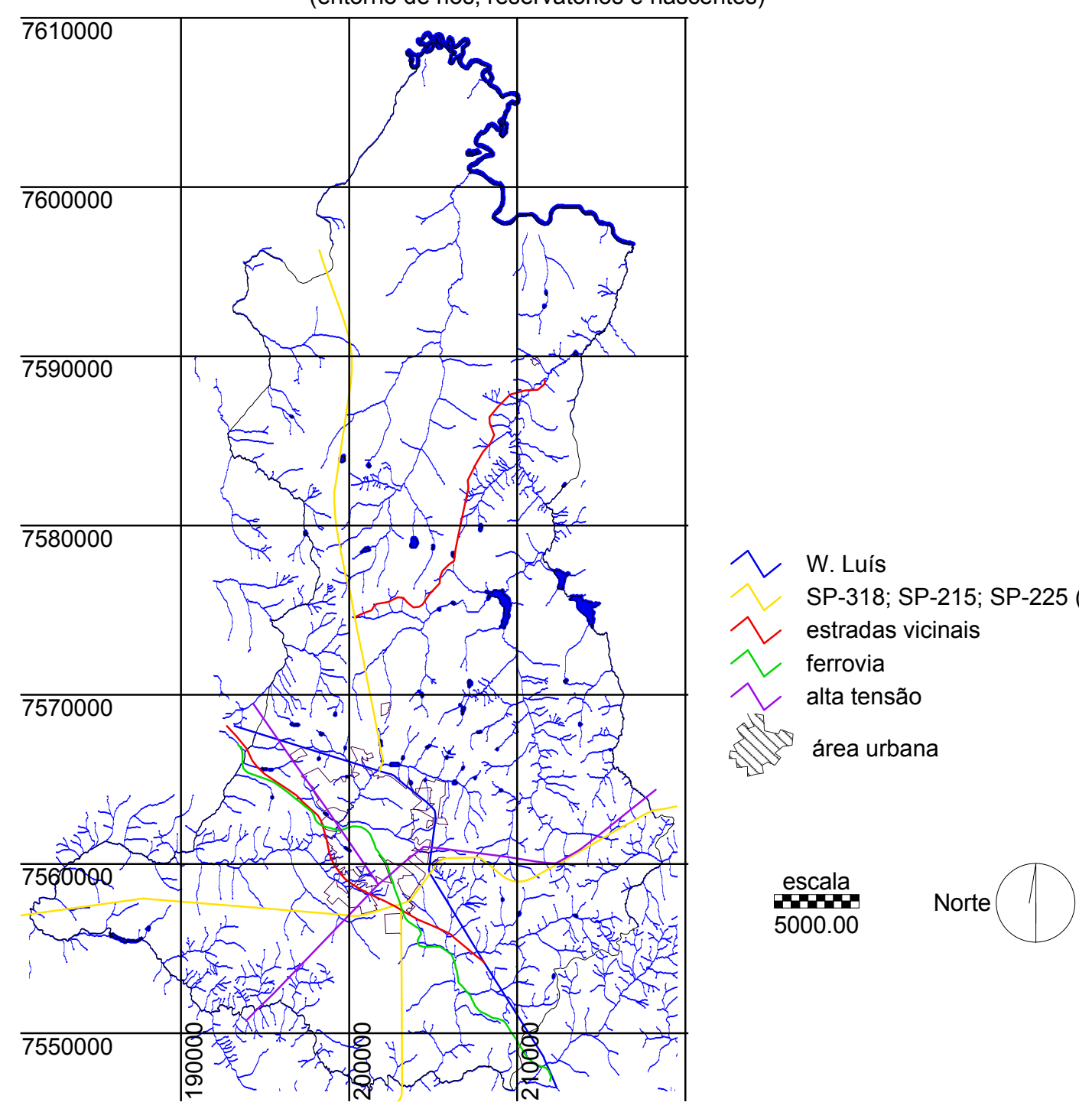

ANEXO B.3. ÁREAS DE PRESERVAÇÃO PERMANENTE 


\section{RESTRIÇÕES À OCUPAÇÃO}

(200 m de corpos d'água e remanescentes de vegetação)

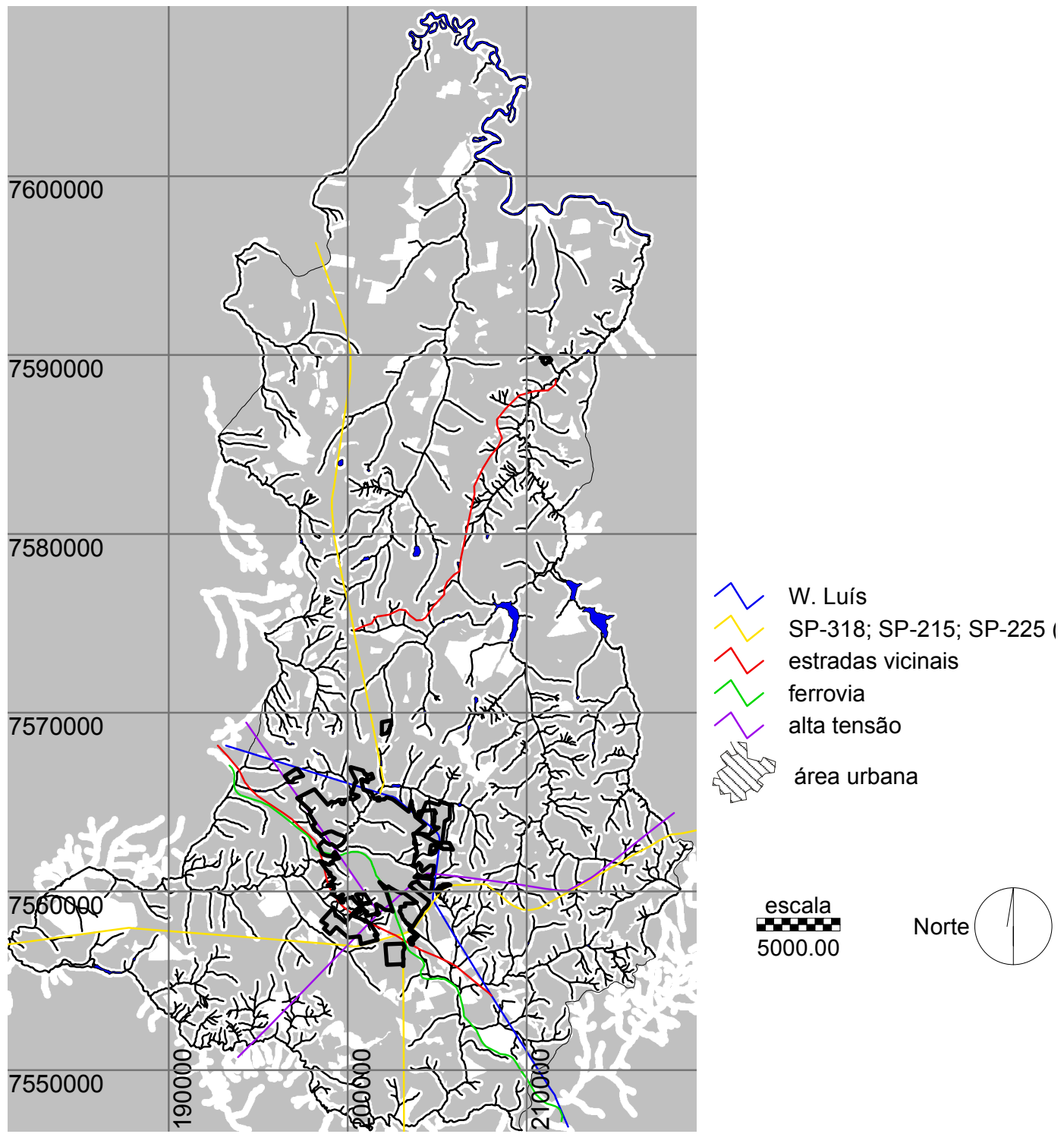

ANEXO B.4. RESTRIÇÕES À OCUPAÇÃO (200 m DE CORPOS D'ÁGUA E REMANESCENTES DE VEGETAÇÃO) 
ANEXO C

MAPAS-SÍNTESE DE VULNERABILIDADES E APTIDÕES 


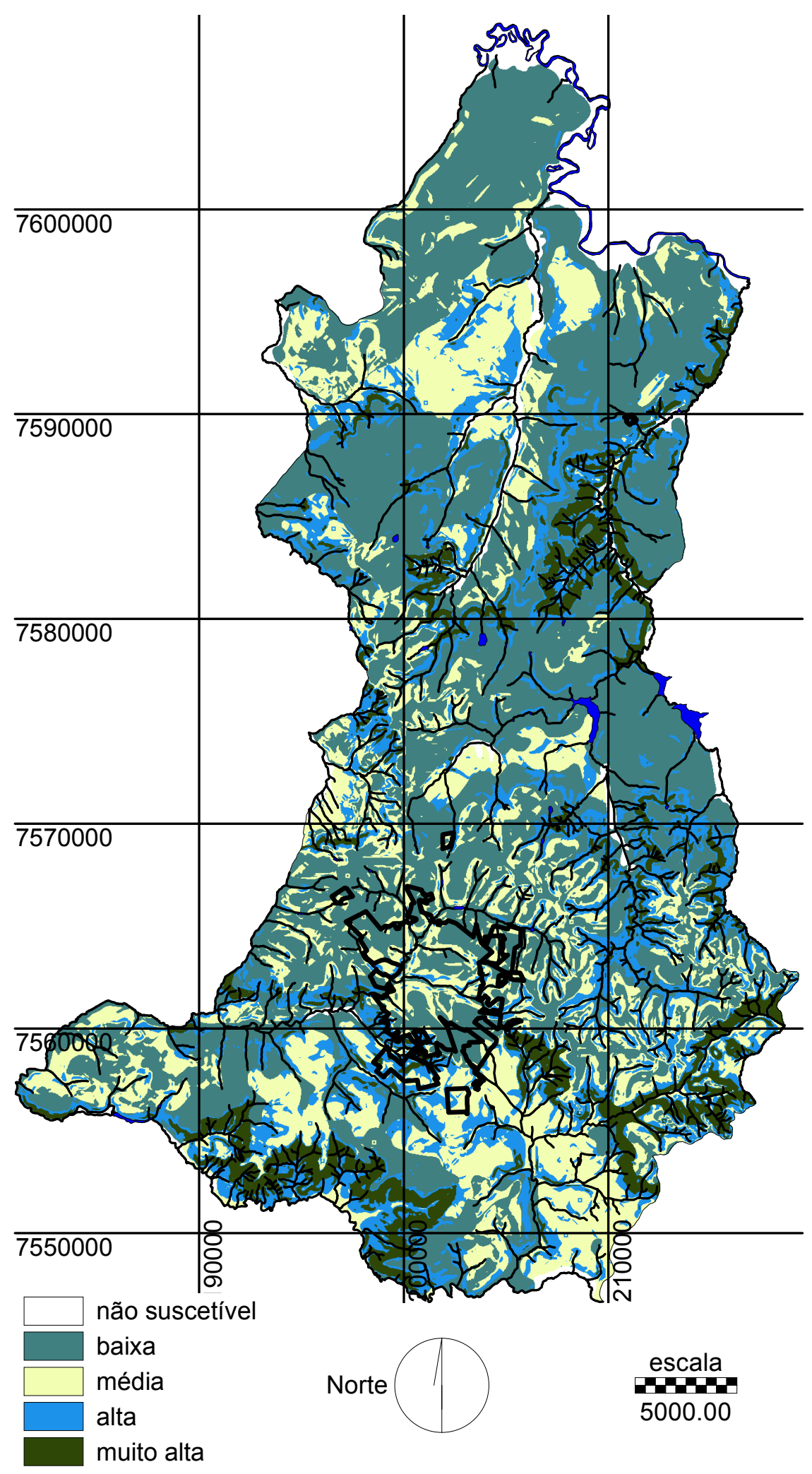

ANEXO C.1. SUSCETIBILIDADE À EROSÃO 
Risco de contaminação de água subterrânea

vulnerabilidade do aqüífero

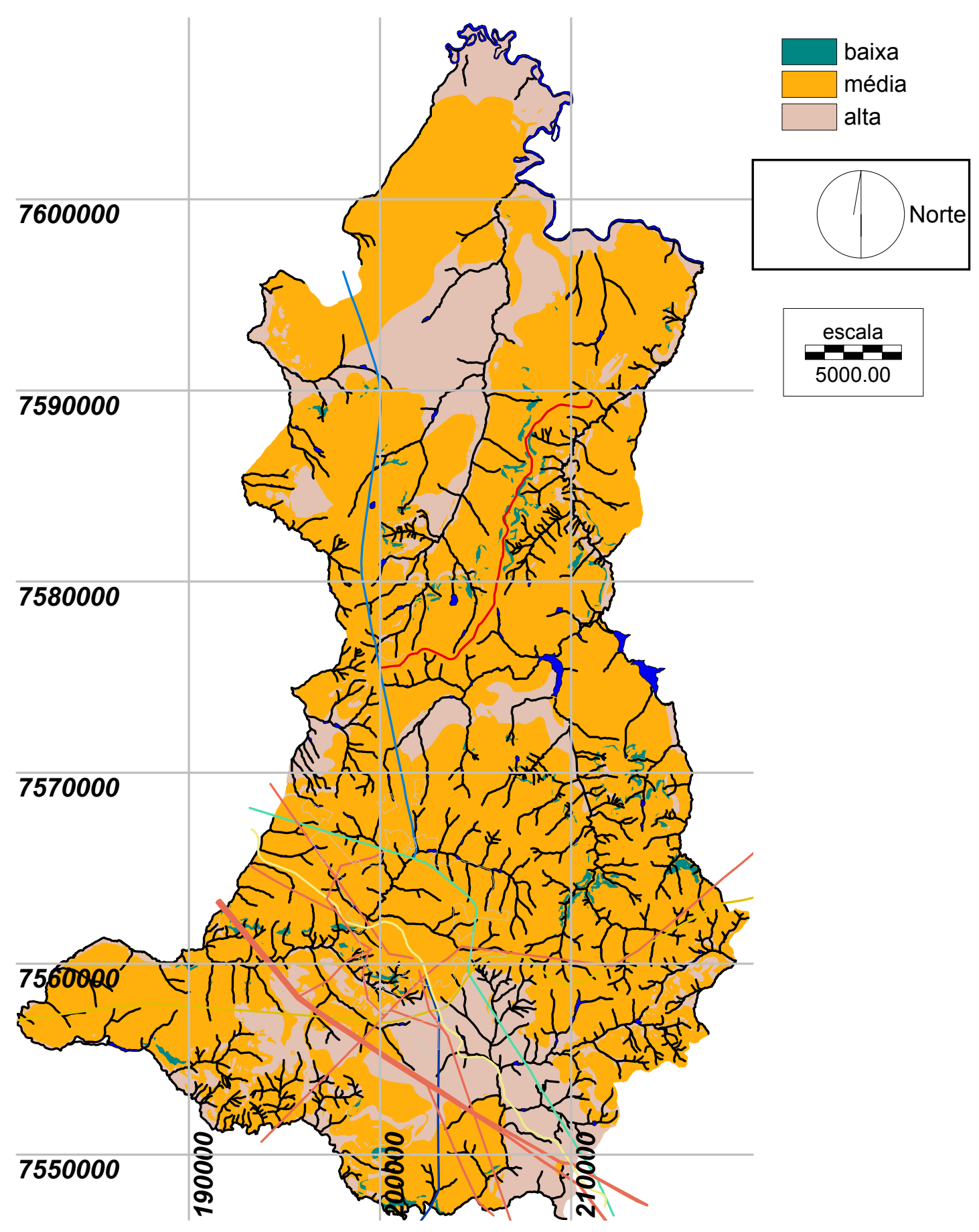

ANEXO C.2. RISCO DE CONTAMINAÇÃO DE ÁGUA SUBTERRÂNEA (vulnerabilidade do aqüífero) 


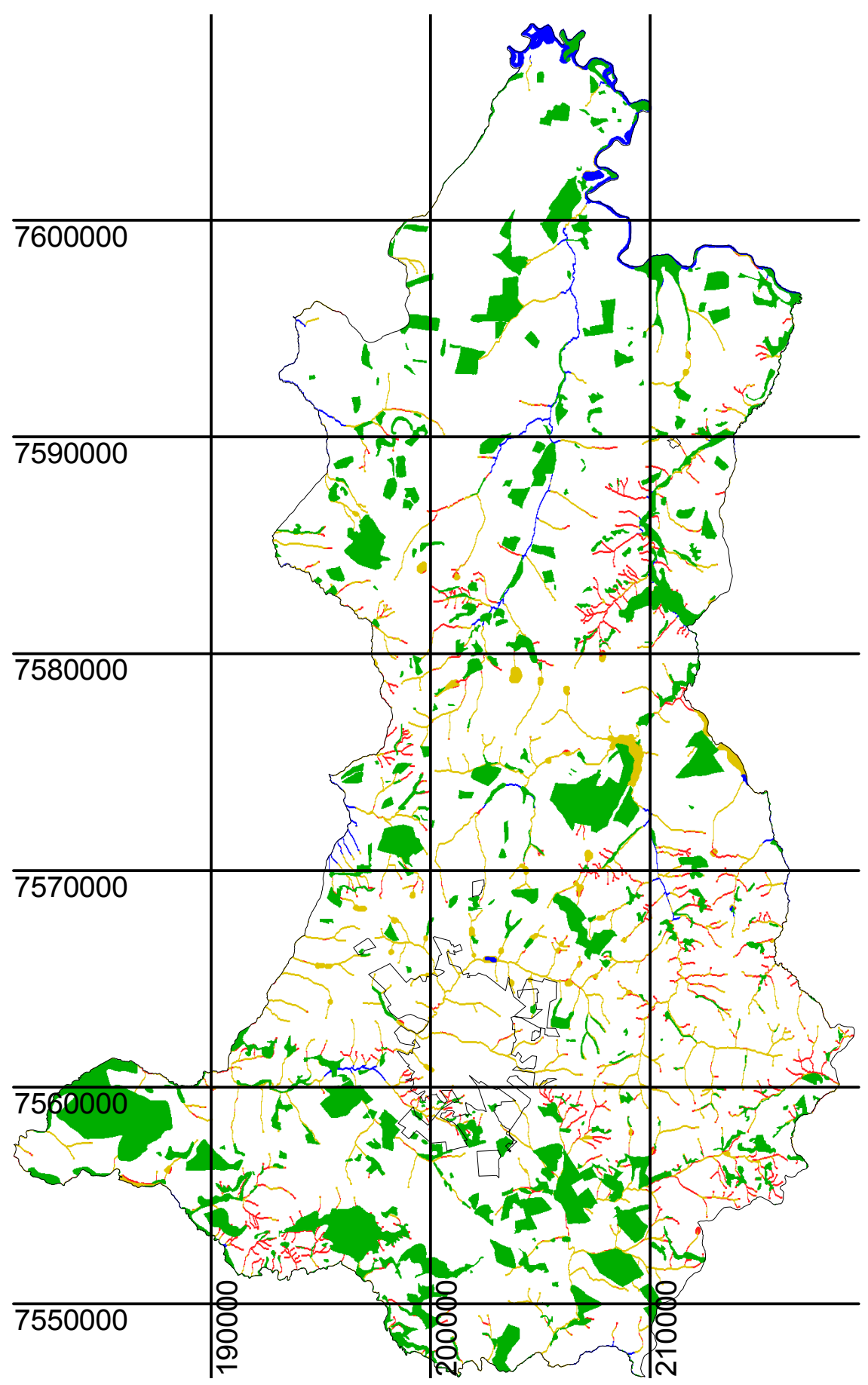

baixo risco (solos hidromórficos)

$\square$ menor risco (baixa suscetibilidade à erosão)

escala maior risco (alta suscetibilidade à erosão) vegetação natural área urbana 5000.00 Norte

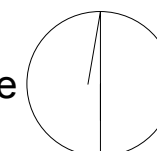




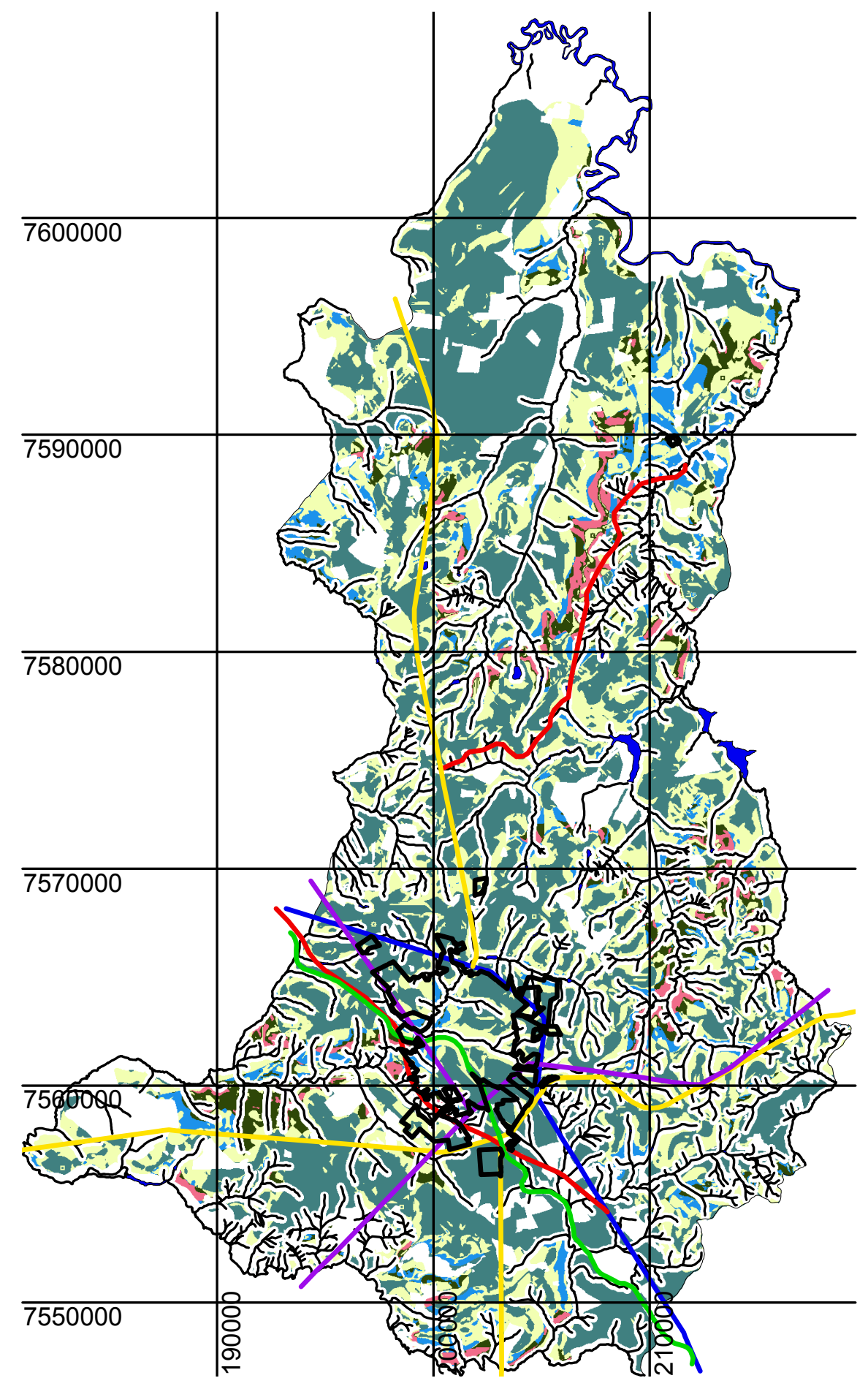

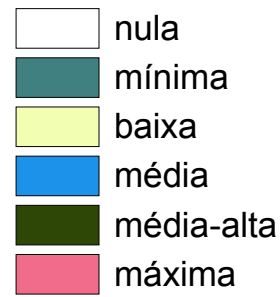

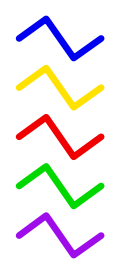

W. Luís

SP-318; SP-215; SP-225 (acesso)

escala

5000.00 estradas vicinais

ferrovia

alta tensão

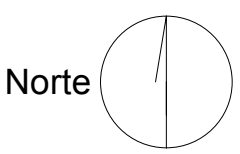

ANEXO C.4. APTIDÃO P/ INSTALAÇÃO DE EMPREENDIMENTOS 
Aptidão para instalação da atividade Indústria TIPO 1 (período de vazão média - Qméd)

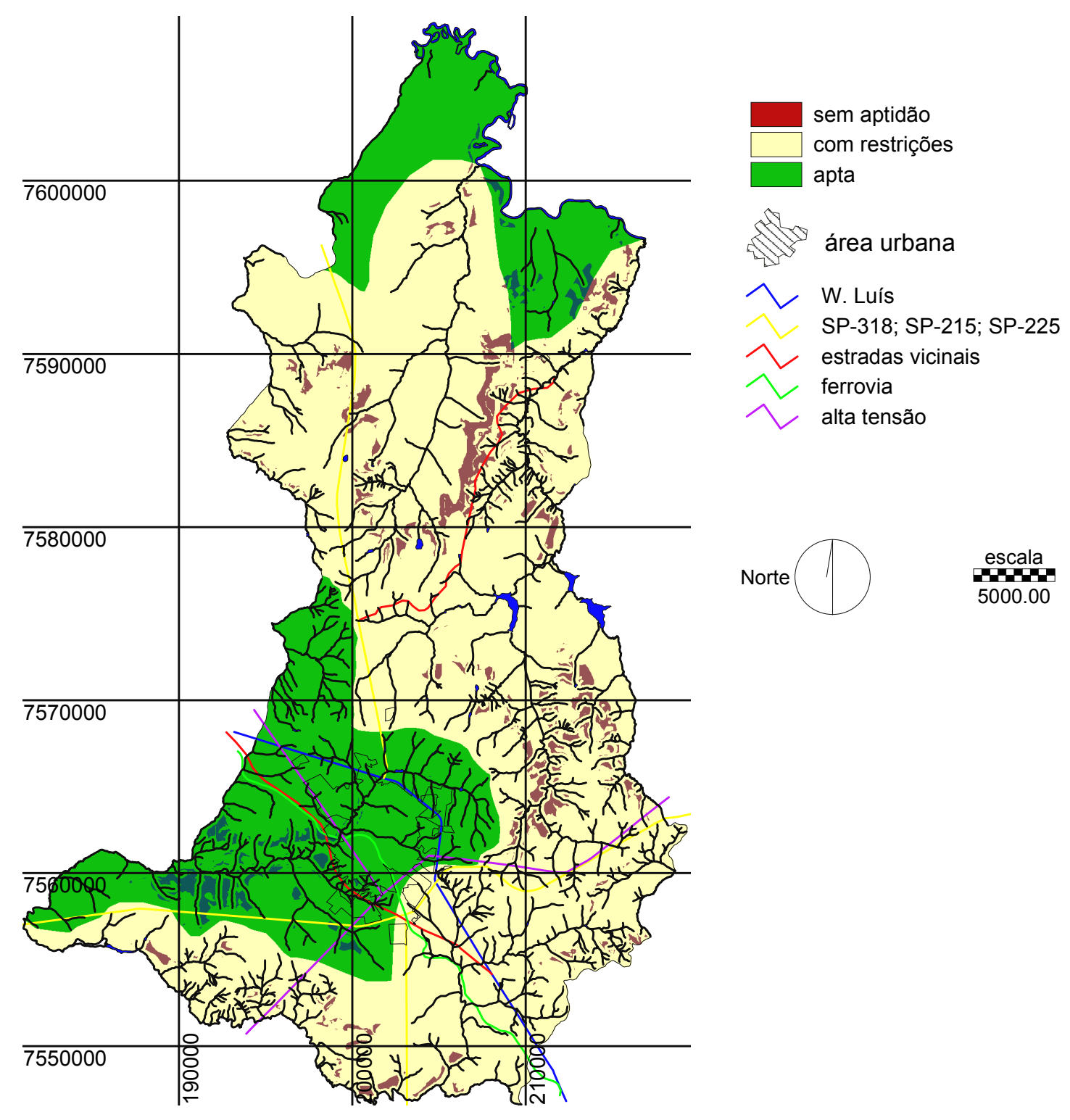

ANEXO C.5. ÁREAS APTAS P/ INSTALAÇÃO DE EMPREENDIMENTOS SOBRE APTIDÃO PARA ATIVIDADE INDÚSTRIA TIPO1, PARA A VAZÃO $\mathbf{Q}_{\text {méd }}$ 
Aptidão para a instalação da atividade Indústria TIPO1 (período de vazões Q95 e Q7,10)

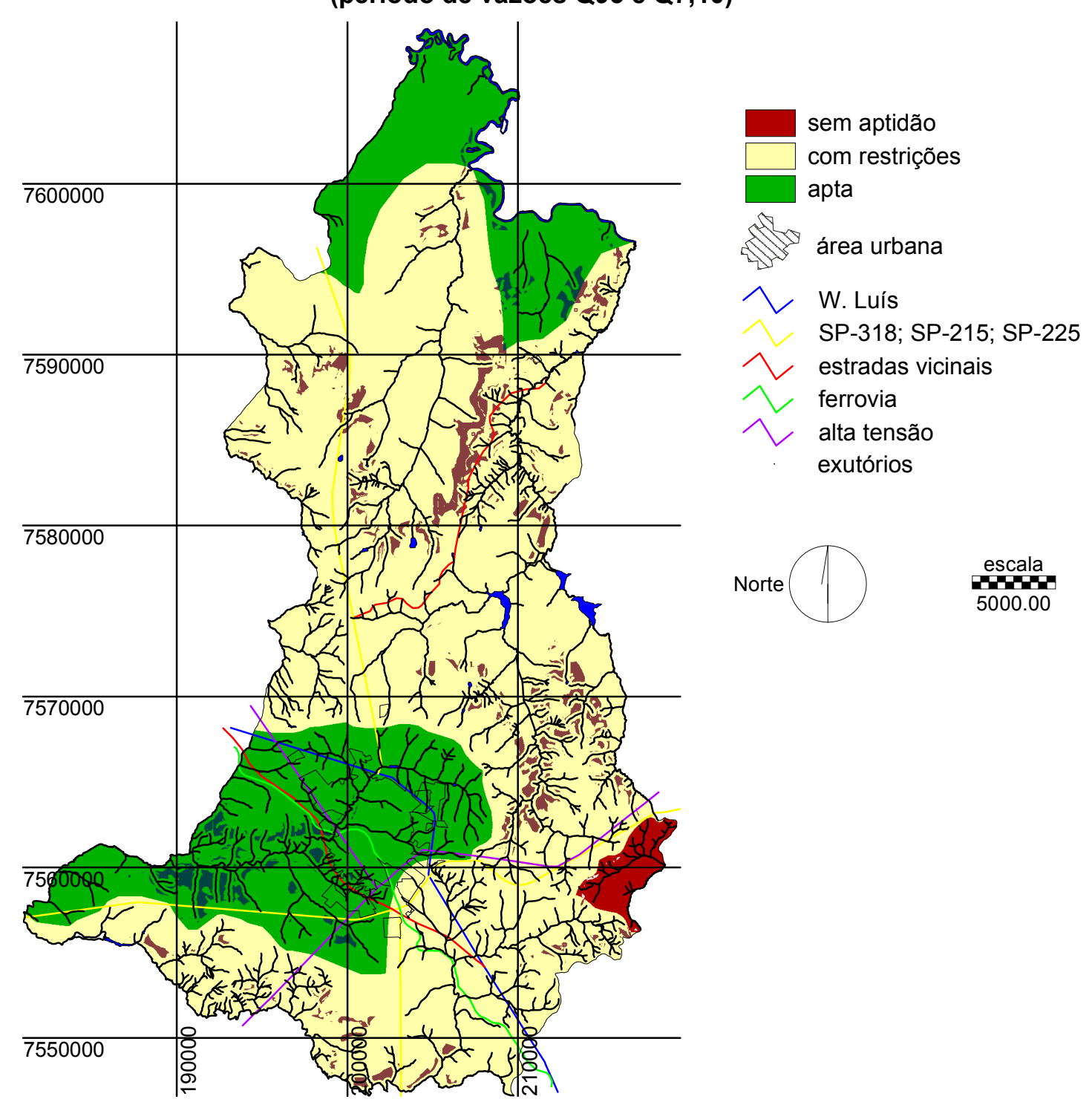

ANEXO C.6. ÁREAS APTAS P/ INSTALAÇÃO DE EMPREENDIMENTOS SOBRE APTIDÃO PARA ATIVIDADE INDÚSTRIA TIPO1, PARA AS VAZÕES $\mathbf{Q}_{95} E \mathbf{Q}_{7,10}$ 
Aptidão para instalação da atividade Indústria TIPO 2 (período de vazão média - Qméd)

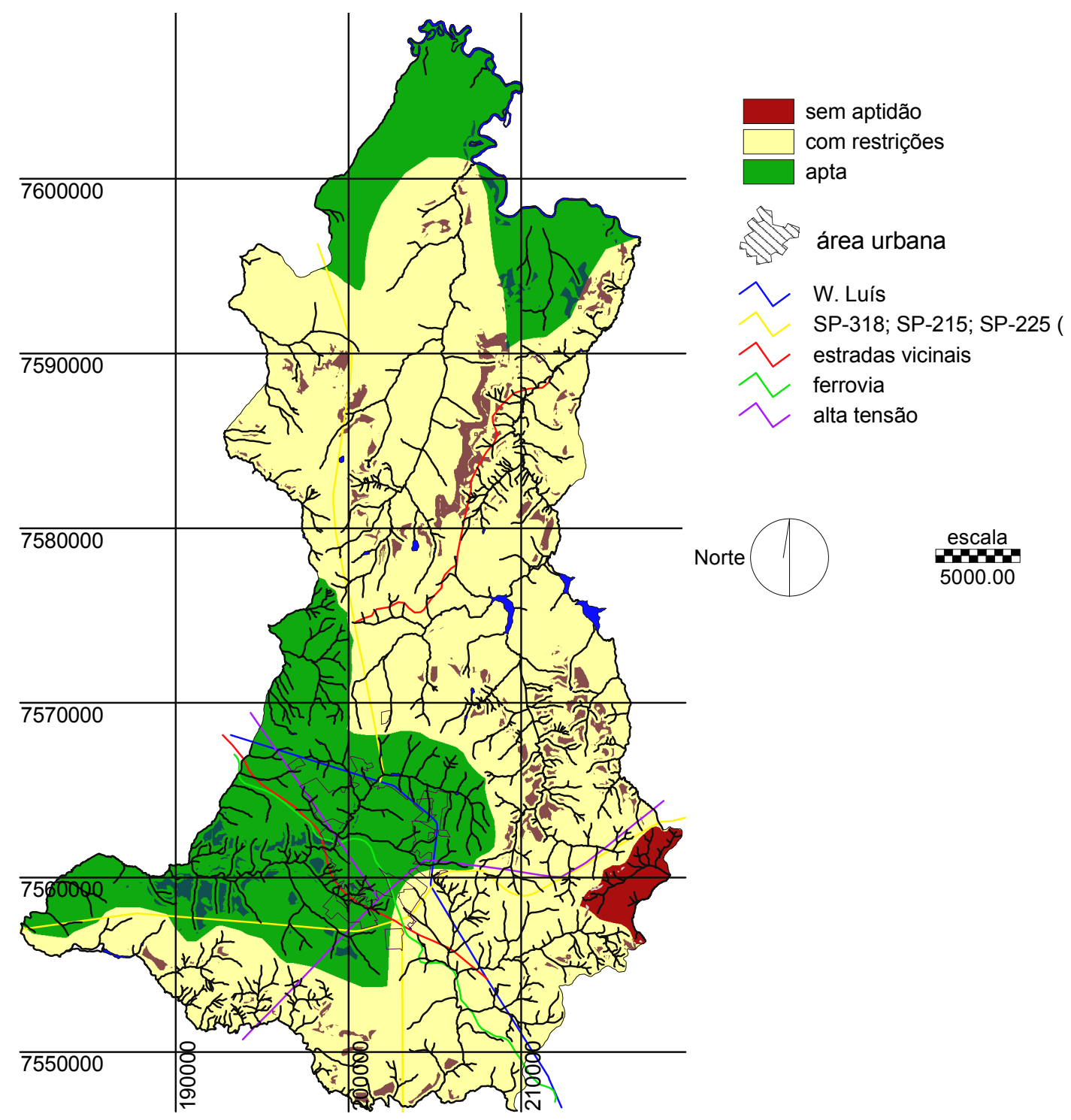

ANEXO C.7. ÁREAS APTAS P/ INSTALAÇÃO DE EMPREENDIMENTOS SOBRE APTIDÃO PARA ATIVIDADE INDÚSTRIA TIPO2, PARA A VAZÃO $\mathbf{Q}_{\text {méd }}$ 
Aptidão para a instalação da atividade Indústria TIPO 2 (período de vazão Q95)

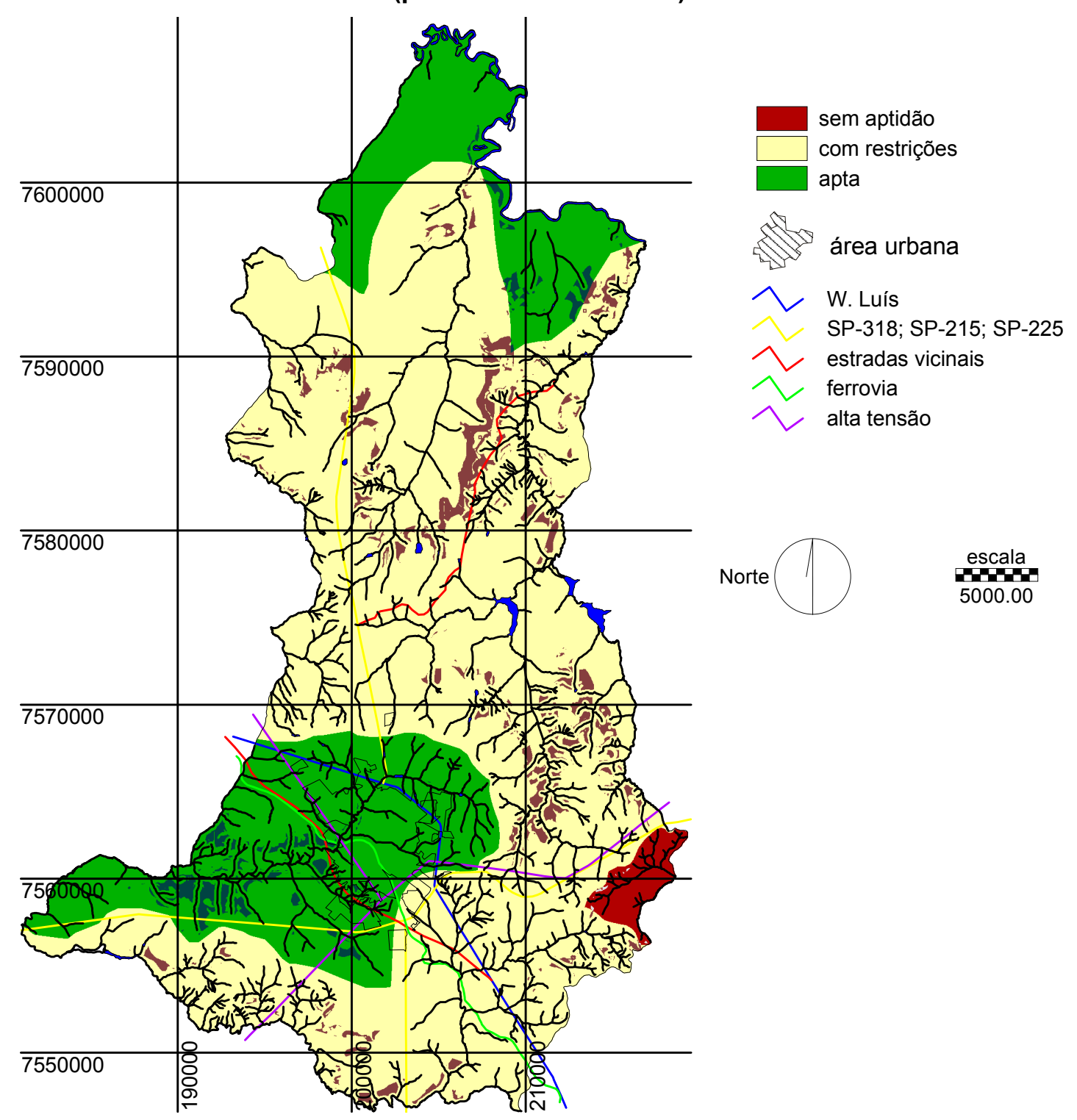

ANEXO C.8. ÁREAS APTAS P/ INSTALAÇÃO DE EMPREENDIMENTOS SOBRE APTIDÃO PARA ATIVIDADE INDÚSTRIA TIPO2, PARA A VAZÃO $Q_{95}$ 
Aptidão para a instalação da atividade Indústria TIPO 2 (período de vazão crítica - Q7,10)

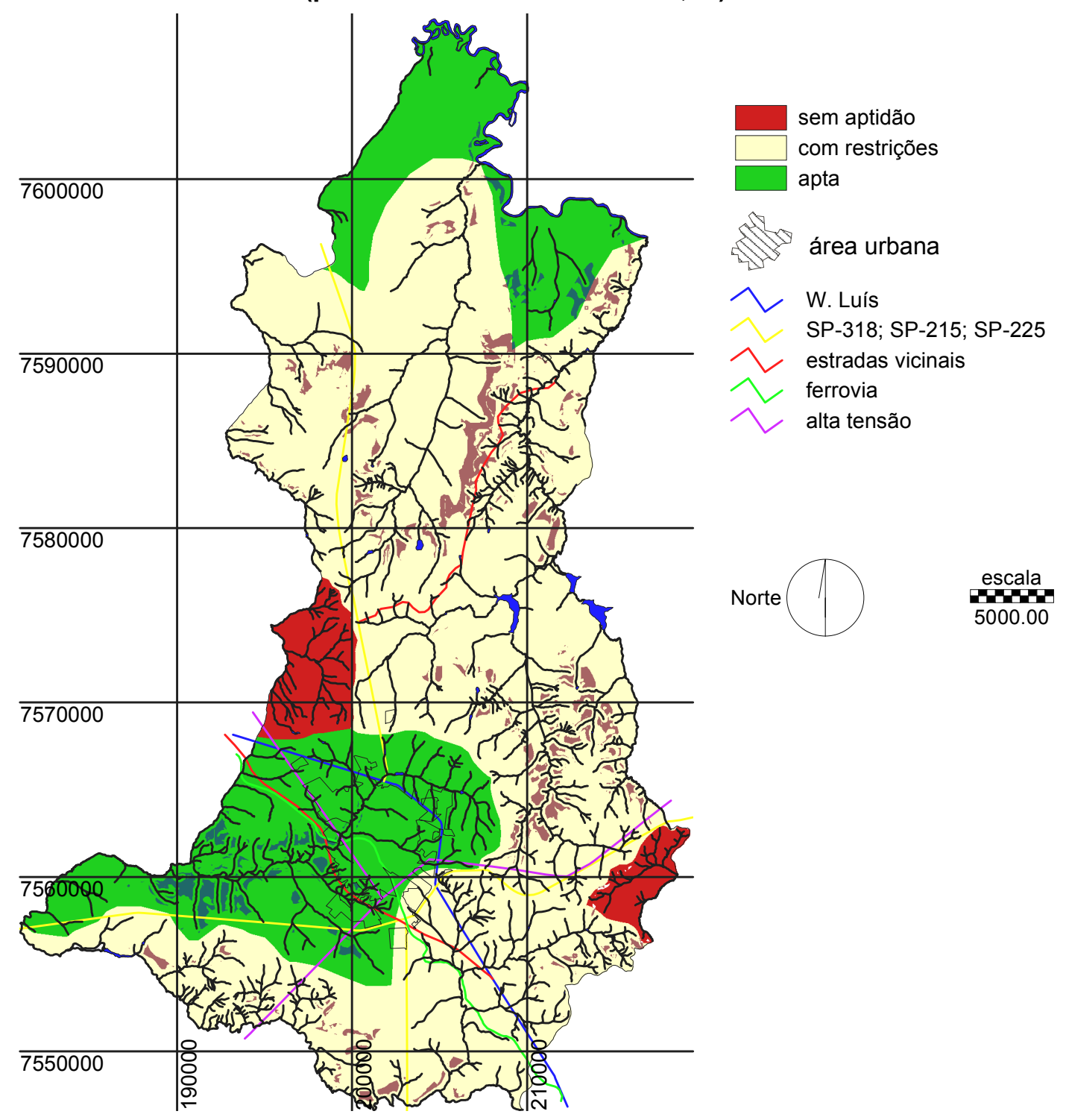

ANEXO C.9. ÁREAS APTAS P/ INSTALAÇÃO DE EMPREENDIMENTOS SOBRE APTIDÃO PARA ATIVIDADE INDÚSTRIA TIPO2, PARA A VAZÃO $\mathbf{Q}_{7,10}$ 
Aptidão para a instalação de ETE (período de vazão média - Qméd)

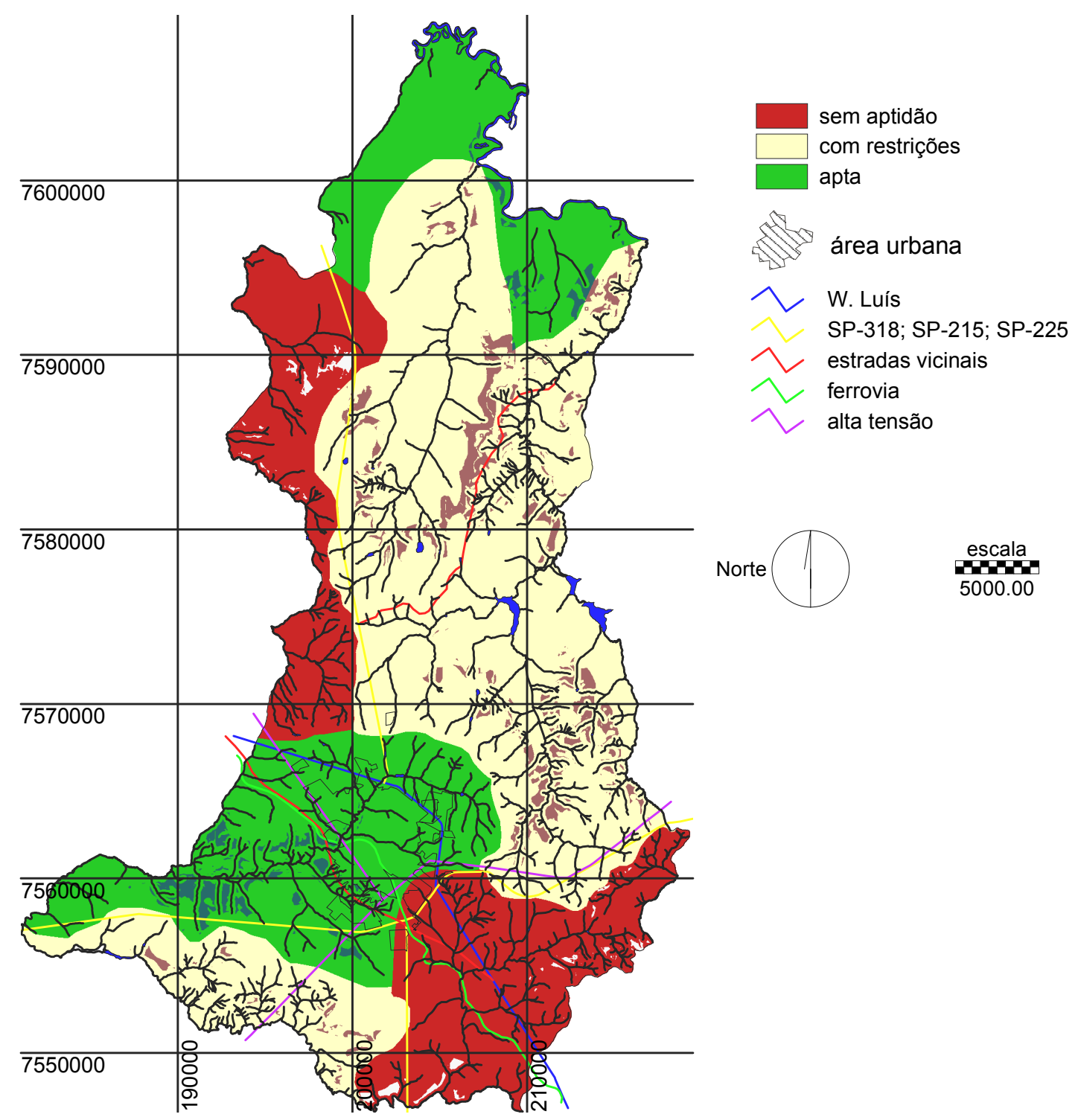

ANEXO C.10. ÁREAS APTAS P/ INSTALAÇÃO DE EMPREENDIMENTOS SOBRE APTIDÃO PARA ETE, PARA A VAZÃO $\mathbf{Q}_{\text {méd }}$ 


\section{Aptidão para instalação de ETE} (período de vazão Q95)

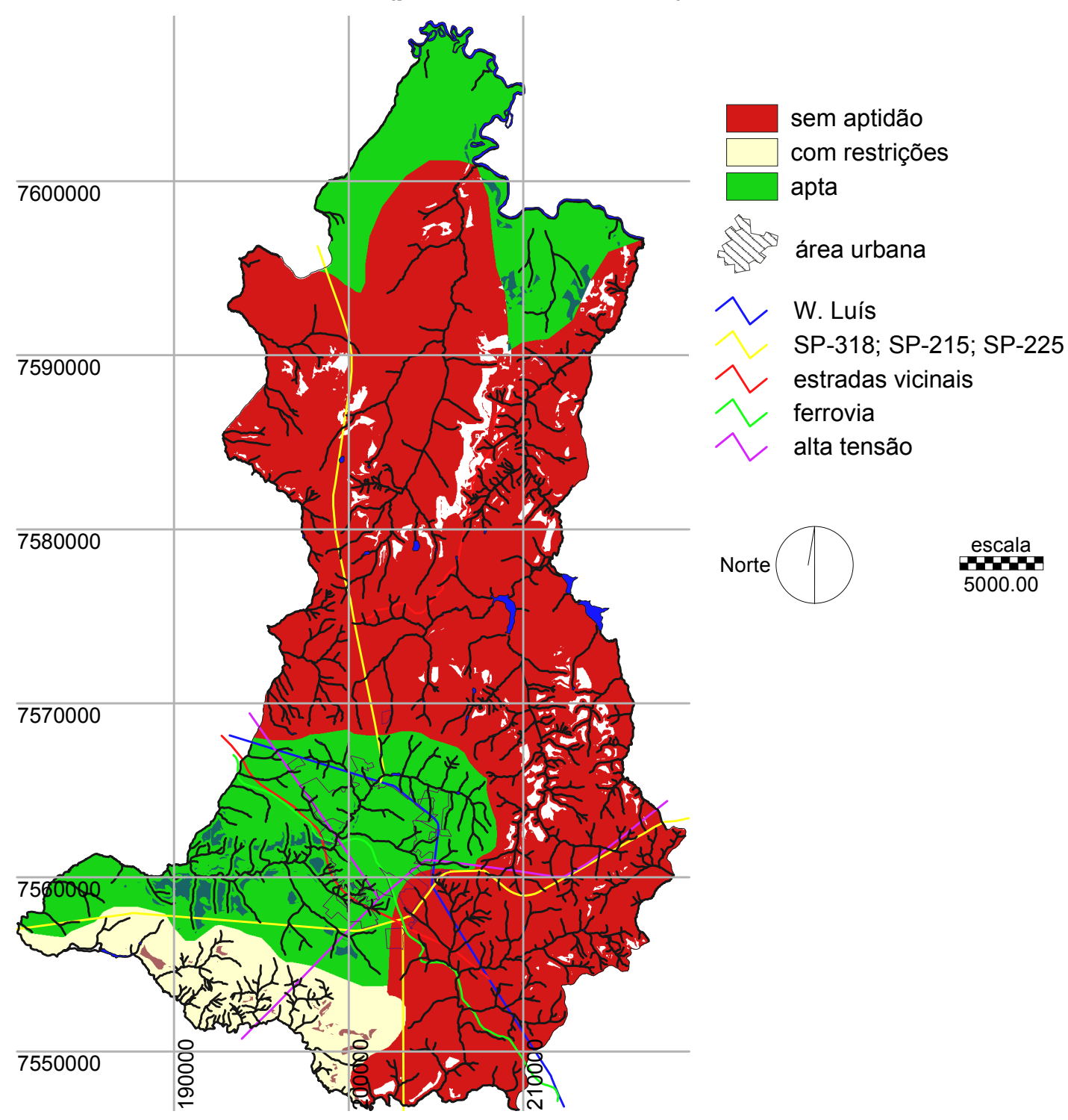

ANEXO C.11. ÁREAS APTAS P/ INSTALAÇÃO DE EMPREENDIMENTOS SOBRE APTIDÃO PARA ETE, PARA A VAZÃO $\mathbf{Q}_{95}$ 


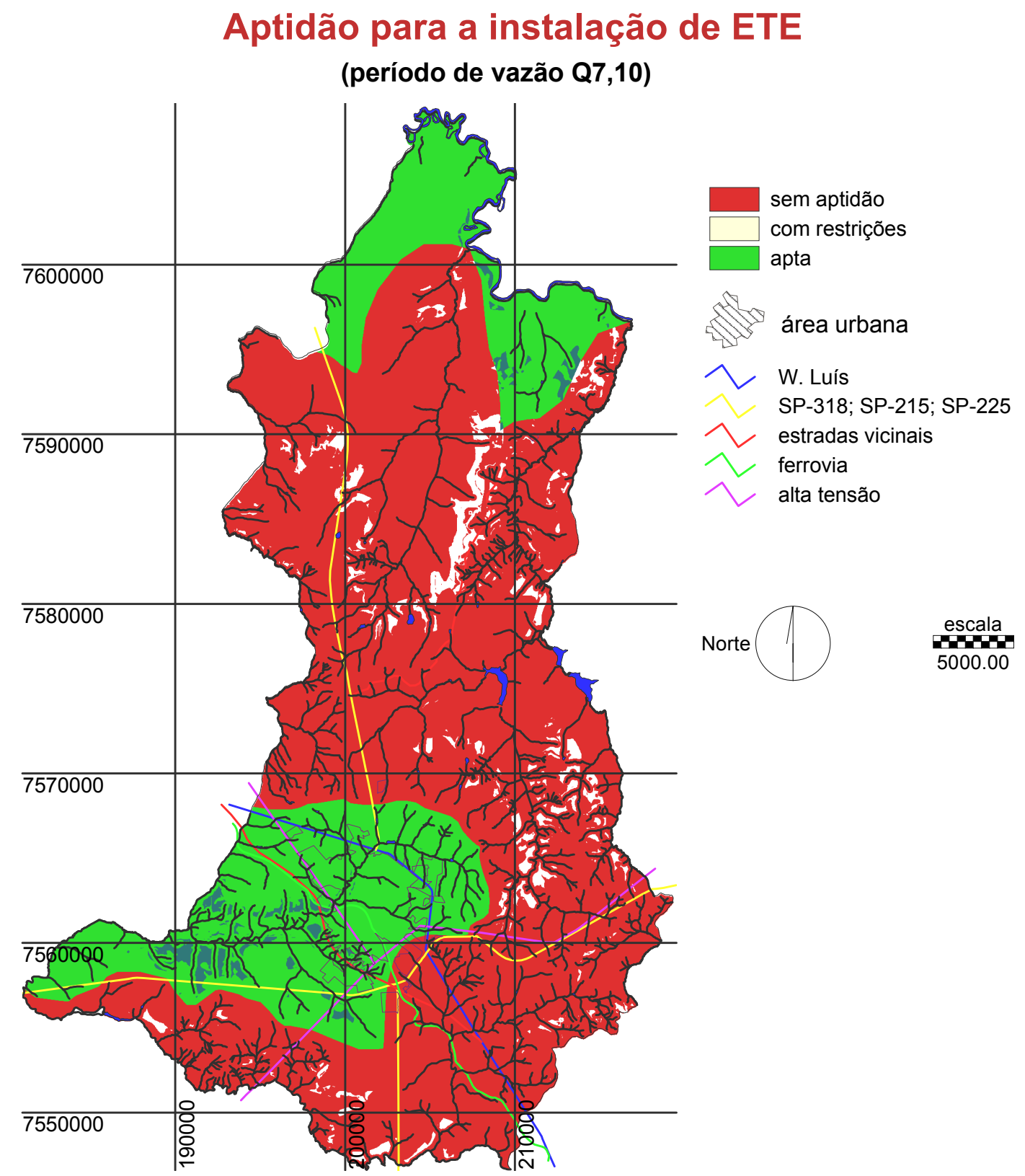

ANEXO C.12. ÁREAS APTAS P/ INSTALAÇÃO DE EMPREENDIMENTOS SOBRE APTIDÃO PARA ETE, PARA A VAZÃO $\mathbf{Q}_{7,10}$ 
Aptidão para captação de água para abastecimento (período de vazão média - Qméd)

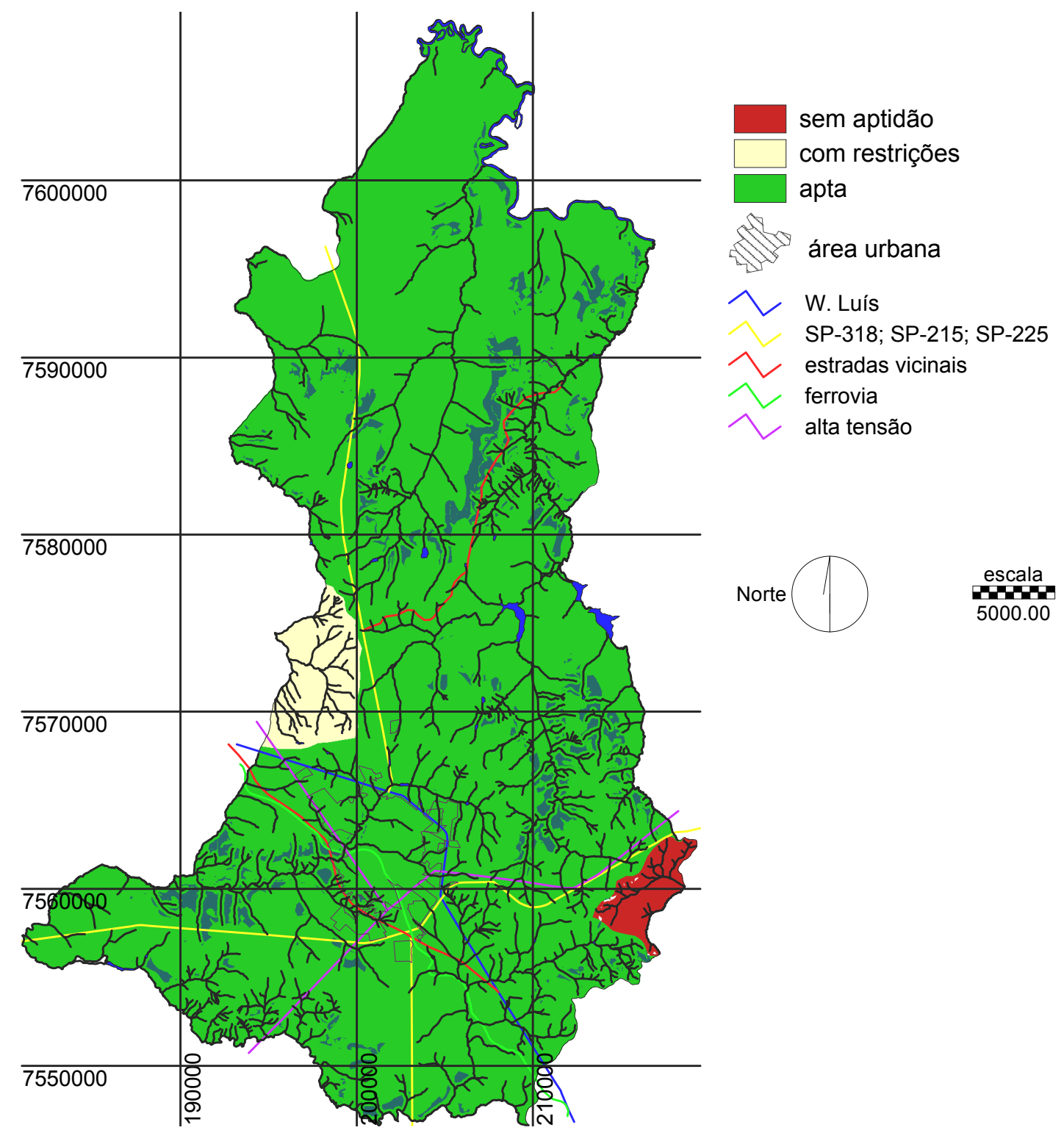

ANEXO C.13. ÁREAS APTAS P/ INSTALAÇÃO DE EMPREENDIMENTOS SOBRE APTIDÃO PARA CAPTAÇÃO DE ÁGUA PARA ABASTECIMENTO, PARA A VAZÃO $\mathbf{Q}_{\text {méd }}$ 


\section{Aptidão para captação de água para abastecimento} (período de vazão Q95)

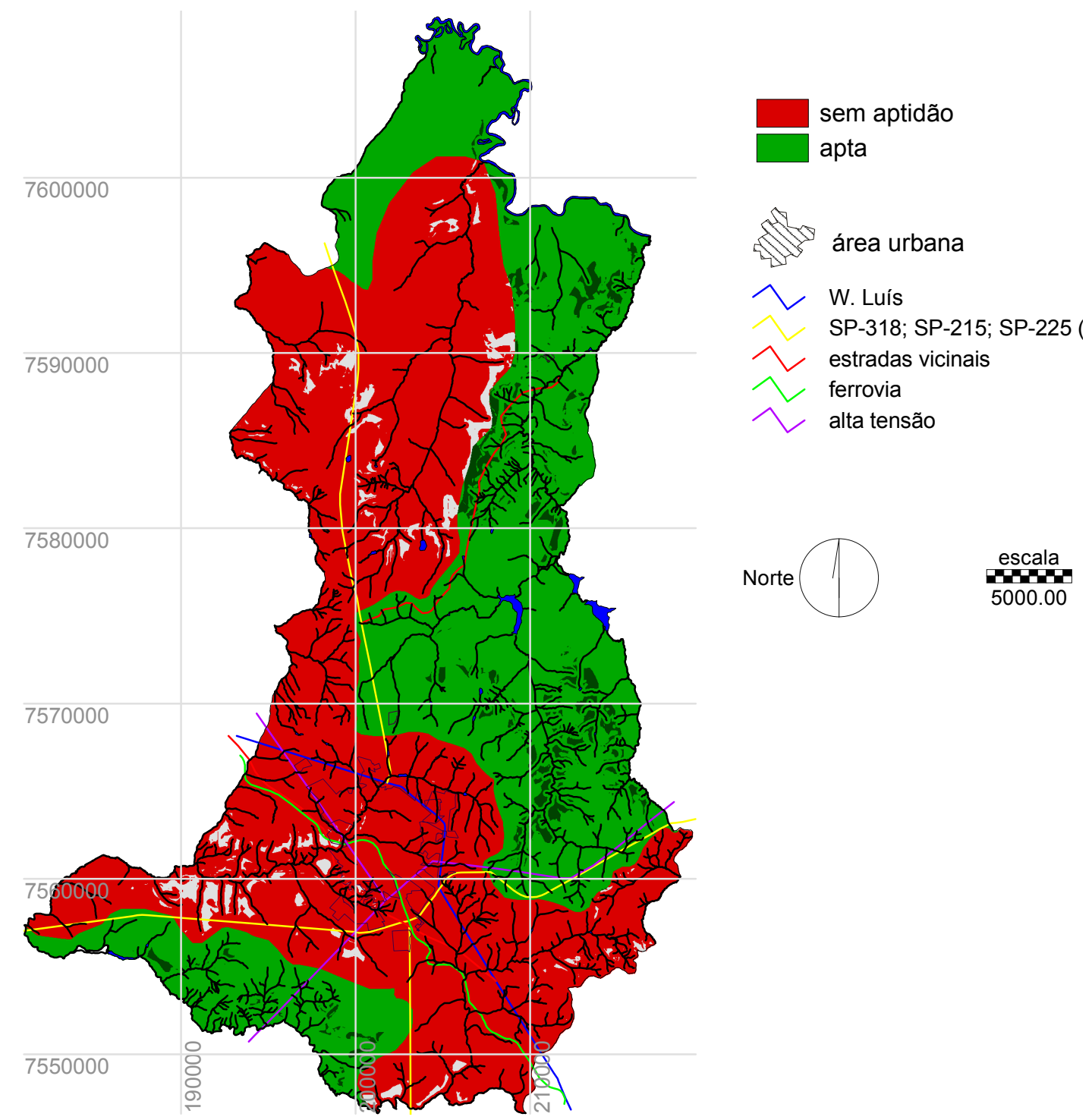

ANEXO C.14. ÁREAS APTAS P/ INSTALAÇÃO DE EMPREENDIMENTOS SOBRE APTIDÃO PARA CAPTAÇÃO DE ÁGUA PARA ABASTECIMENTO, PARA A VAZÃO $Q_{95}$ 


\section{REFERÊNCIAS BIBLIOGRÁFICAS}

Ab'SABER, A. N. (1989). Zoneamento Ecológico-Econômico na Amazônia questões de escala e método. In: Estudos Avançados, v. 3, n. 5, p. 4-19, jan./abr. São Paulo.

ACRE (2000). Governo do Estado do Acre. Programa Estadual de Zoneamento Ecológico-Econômico do Estado do Acre. Zoneamento ecológico-econômico: indicativos para a gestão territorial do Acre - documento final. Rio Branco: SECTMA. Vol. III.

ALMEIDA, J. R. de et al. (1999). Planejamento ambiental: caminho para participação popular e gestão ambiental para nosso futuro comum: uma necessidade, um desafio. 2. ed. Rio de Janeiro. Thex Editora. Biblioteca Estácio de Sá.

ARAÚJO, I. de C. P; FREITAS, M. A. V; RIBEIRO, E. S.; SABBAG, S. K. (1999). Monitoramento da qualidade das águas no Brasil. In: FREITAS, M. A. V (org.). O estado das águas no Brasil. $2^{\mathrm{a}}$ impressão. Brasília, DF. ANEEL, SIH; MMA, $\mathrm{SRH}$; MME.

ASHWORT, G. J. (1995). Planning for Environmental Quality. Research Program for Urban and Regional Planning. University of Gröening, Holanda. http://www.frw.rug.nl/plan/plan1uk.htm (04/01/2001).

AYRES, E. de O. J. (1991). Parâmetros para Localização de Áreas e Distritos Industriais, com o objetivo de Avaliação de Impactos sobre a Estrutura Urbana. São Paulo. 137 p. Dissertação (Mestrado). Faculdade de Arquitetura e Urbanismo, Universidade de São Paulo.

BARBIERI, J. C. (1997). Desenvolvimento e Meio Ambiente: as estratégias de mudança da Agenda 21. Petrópolis. Ed. Vozes. 
BASTOS, A. C. S.; FREITAS, A. C. (2000). Agentes e processos de interferência, degradação e dano ambiental. In: CUNHA, S. B; GUERRA, A. J. T. (orgs.). Avaliação e Perícia Ambiental. 2. ed. Rio de Janeiro. Bertrand Brasil, p. 17-76.

BATTY, M.; DENSHAM, P. J. (1996). Decision Support, GIS, And Urban Planning. http://www.geolog.ocl.ac.uk/ pdensham (20/07/00).

BECKER, B. K.; EGLER, C. A. G. (1996). Detalhamento da metodologia para execução do zoneamento ecológico-econômico pelos estados da Amazônia Legal. Brasília. 43 p. Secretaria de Assuntos Estratégicos da Presidência da República (SAE/PR) e Ministério do Meio Ambiente, dos Recursos Hídricos e da Amazônia Legal.

BEGOSSI, A. (2001). Escalas, economia ecológia e a conservação da biodiversidade. In: CAVALCANTI, C. (org.). Meio Ambiente, Desenvolvimento Sustentável e Políticas Públicas. 3. ed. São Paulo: Ed. Cortez; Recife: Fundação Joaquim Nabuco, p. 56-71.

BERTONI, J. \& LOMBARDI Neto, F. (1990). Conservação do solo. São Paulo. 355 p. Ed. Ícone.

BINSWANGER, H. C. (2001). Fazendo a sustentabilidade funcionar. In: CAVALCANTI, C. (org.). Meio Ambiente, Desenvolvimento Sustentável e Políticas Públicas. 3. ed. São Paulo; Ed. Cortez; Recife: Fundação Joaquim Nabuco, p. 41-55.

BRANCO, S. M. (1997). O meio ambiente em debate. 26. ed. São Paulo, 96 p. Ed. Moderna.

BUSTRÖM, F. \& KORHONEN, J. (2001). Municipalities and Industrial Ecology: reconsidering municipal environmental management. Sustainable Development, $n^{\circ}$ 9, p. 36-46. John Wiley \& Sons e ERP Environment.

CAMPOS, J. R. (1991). Alternativas para tratamento de esgotos sanitários. Texto preparado para o $1^{\circ}$ CURSO DE RECICLAGEM EM SANEAMENTO, RECURSOS HÍDRICOS E MEIO AMBIENTE, promovido pelo Consórcio Intermunicipal das Bacias dos Rios Piracicaba e Capivari. São Paulo. Édile.

CANTER, L. W. (1996). Environmental Impact Assessment. 2. ed. Nova lorque. 660 p. McGraw-Hill. 
CAVALCANTI, C. (2001). Política de governo para o desenvolvimento sustentável: uma introdução ao tema e a esta obra coletiva. In: CAVALCANTI, C. (org.). Meio Ambiente, Desenvolvimento Sustentável e Políticas Públicas. 3. ed. São Paulo: Ed. Cortez; Recife: Fundação Joaquim Nabuco, p. 23-40.

CETESB (2001). Relatório de Qualidade das Águas Interiores do Estado de São Paulo 2000. São Paulo, 138 p. Série Relatórios/CETESB.

CHARLES, A. J. (1998). Beyond Zoning: Land Use Controls in the Digital Economy. Policy Summary $\mathrm{n}^{\circ}$ 106s. Cascade Policy Institute. Portland. http://www.cascadepolicy.org/publications.asp (21/12/2000).

DAEE (1988). Regionalização Hidrológica no Estado de São Paulo. Revista Águas e Energia Elétrica. DAEE. Ano 5, n. 14. In: Sistema de Informações para Gerenciamento de Recursos Hídricos do Estado de São Paulo - SIGRH. (CDROM). São Paulo. Fundação Centro Tecnológico de Hidráulica.

DALY, H. (1991). Ecological Economics and Sustainable Development: from concept to policy. World Bank Environment Department, Divisional Working Paper n. ${ }^{\circ}$ 1991-24. Washington, D.C. World Bank.

DAVIS, C.; FONSECA, F. (2001). Introdução aos Sistemas de Informação Geográficos. Curso de Especialização em Geoprocessamento. Belo Horizonte. UFMG - Instituto de Geociências, Departamento de Cartografia.

DAVIS Jr., C. A. (1999). Múltiplas representações em bancos de dados geográficos. (CD-ROM). In: CONGRESSO E FEIRA PARA USUÁRIOS DE GEOPROCESSAMENTO DA AMÉRICA LATINA, 5., Salvador, 1999. Anais. Curitiba.

Di BONA (2000). Environmental Zoning to Help Check Sprawl. The Streamer Newsletter - Spring 2000. Charles River Watershed Association. Boston - MA. http://www.crwa.org (21/12/2000).

EASTMAN, J. R. (1997). IDRISI for Windows User's Guide version 2.0. Introduction. Worcester - MA. Graduate School of Geography. Clark University.

EASTMAN, J. R. (1998). IDRISI for Windows: Introdução e Exercícios Tutoriais. Editores da versão em português: Heinrich Hasenack e Eliseu Weber. Porto Alegre. UFRGS, Centro de Recursos IDRISI. 
ESPÍNDOLA, E. L. G.; SILVA, J. S. V.; MARINELLI, C. E.; ABDON, M. M. (orgs.) (2000). A Bacia Hidrográfica do Rio do Monjolinho: uma abordagem ecossistêmica e a visão interdisciplinar. São Carlos, 188 p. Ed. RIMA.

FILET, M. (1995). Plano de gerenciamento da região lagunar de lguape e Cananéia. In: Tauk, S.M. (org.). Análise ambiental: uma visão multidisciplinar. São Paulo, UNESP, p.141-142.

FLAVIN, C. (2001). Planeta Rico, Planeta Pobre. In: O Estado do Mundo 2001: bíblia do meio ambiente. Relatório anual do Worldwatch Institute em direção a uma sociedade sustentável. WWI/UMA - Universidade Livre da Mata Atlântica. Curitiba. UMA Editora.

FONTES, A. T. (1997). Aspectos do macrozoneamento utilizando SIG enquanto instrumento de gestão ambiental: diagnósticos e cenários regionais no estudo de caso da região de Ribeirão Preto. São Carlos. 67 p. Dissertação (Mestrado). Escola de Engenharia de São Carlos, Universidade de São Paulo.

GOODCHILD, M. F. (1993). The state of GIS for environmental problem-solving. In: GOODCHILD et al. Environmental Modelling and GIS. New York. Oxford University Press. p. 8-15.

GRECCHI, R. C. (1998). Zoneamento geoambiental da região de Piracicaba - SP, com auxílio de geoprocessamento. São Carlos. 132 p. Dissertação (Mestrado). Escola de Engenharia de São Carlos, Universidade de São Paulo.

GRINOVER, L. (1989). O planejamento físico-territorial e a dimensão ambiental. Cadernos FUNDAP. São Paulo, ano 9, n. ${ }^{\circ} 16$, junho, 1989. Págs. 25-32.

HOMMA, A. (2000). Zoneamento da Amazônia é a solução? Gazeta Mercantil, Belém, 29/06/2000, p.2.

IPT (1981). Mapa Geológico do Estado de São Paulo. Escala 1:500 000. Vol. I. São Paulo. Instituto de Pesquisas Tecnológicas - IPT. Divisão de Minas e Geologia Aplicada.

IPT (2000). Diagnóstico da situação atual dos Recursos Hídricos e estabelecimento de diretrizes técnicas para a elaboração do Plano da Bacia Hidrográfica do Tietê/Jacaré - Relatório Zero. (CD-ROM). São Paulo. Relatório IPT 40.674/00. Instituto de Pesquisas Tecnológicas - IPT. 
JOHN, L. (2001). O zoneamento de cada um. Texto eletrônico. O Estado de São Paulo, seção ECOS da Terra, http://www.estadao.com.br/ciencia/colunas/ ecos/2001. (08/09/2001).

JOURAVLEV, A. (2001). Administración del agua en América Latina y el Caribe en el umbral del siglo XXI. Comissão Econômica para América Latina e Caribe. (CEPAL). Série Recursos Naturales e Infraestructura, $n^{\circ} 27$, julho. Santiago Chile. 77 pág.

KRONEMBERGER, D. M. P; CARVALHO, C. N. (1999). Modelagem e análise de cenários de uso do solo como auxílio à tomada de decisão para o desenvolvimento sustentável do Município de Angra dos Reis (RJ). Trabalho apresentado no evento Meio Ambiente 99, organizado pela Universidade Técnica de Hamburgo-Harburgo. http://www.projekte.org/ meioambiente99/tema03/text.html. (12/12/2000).

LIMA, C. A. A. (1997). O uso do modelo QUAL2E na simulação da qualidade das águas do rio Jacaré-Guaçu. São Carlos. 179 p. Dissertação (Mestrado). Escola de Engenharia de São Carlos, Universidade de São Paulo.

LIMA-E-SILVA, P. P.; GUERRA, A. J. T.; DUTRA, L. E. D. (2000). Subsídios para avaliação econômica de impactos ambientais. In: CUNHA, S. B; GUERRA, A. J. T. (orgs.). Avaliação e Perícia Ambiental. $2^{a}$ edição. Rio de Janeiro. Bertrand Brasil. págs. 217-261.

MACEDO, R. K. de (1998). O que são e para que servem os zoneamentos ambientais. Texto eletrônico. Portal Brazilian Environmental Mall. http://www.bem.com.br (20/09/2001).

MACEDO, R. K. de (2001). Zonear é sinônimo de ordenar. Texto eletrônico. Portal Brazilian Environmental Mall. http://www.bem.com.br. (14/11/2001).

MACHADO, P. A. L. 1992. Direito Ambiental Brasileiro. 4ª edição. São Paulo. 606 p. Editora Malheiros.

MAGNANI, M. (2000). Abordagem integrada de aspectos conceituais relacionados à adequação ambiental em manufatura. São Carlos. 123 p. Dissertação (Mestrado). Escola de Engenharia de São Carlos, Universidade de São Paulo. 
MAGNANI, M.; MONTAÑO, M.; FONTES, A. T.; SOUZA, M. P. (1999). Utilização de SIG na análise de fatores ambientais para localização de atividades industriais no município de São Carlos - SP. (CD-ROM). In: CONGRESSO E FEIRA PARA USUÁRIOS DE GEOPROCESSAMENTO DA AMÉRICA LATINA, 5, Salvador, 1999. Anais. Curitiba.

MERCADANTE, M. (2001). O ZEE de Rondônia. mercadante@terra.com.br $(13 / 03 / 2001)$.

MERICO, L. F. K. (1996). Introdução à Economia Ecológica. Blumenau. 160 p. Editora da FURB.

MILARÉ, E. (1999). Instrumentos legais e econômicos aplicáveis aos municípios. Sistema Municipal de Meio Ambiente - SISMUNA/SISNAMA. In: PHILIPPI Jr., A. et al. (editores) (1999). Municípios e meio ambiente: perspectivas para a municipalização da gestão ambiental no Brasil. São Paulo. Associação Nacional de Municípios e Meio Ambiente.

MILLIKAN, B. H. (1998). Zoneamento Sócio-Econômico-Ecológico e Políticas Públicas no Estado de Rondônia: Oportunidades, Limites e Desafios para o Desenvolvimento Sustentável. Projeto BRA/94/007, Cooperação Técnica do PNUD ao PLANAFLORO. Porto Velho/RO.

MILLIKAN, B. H. \& PRETTE, M. E. (2000). SEMINÁRIO: AVALIAÇÃO DA METODOLOGIA DO ZONEAMENTO ECOLÓGICO-ECONÔMICO PARA A AMAZÔNIA LEGAL, Manaus - AM, 03 a 05 de outubro de 2000. Documento Base para Discussão. Ministério do Meio Ambiente. Secretaria de Coordenação da Amazônia - SCA. Secretaria de Políticas para o Desenvolvimento Sustentável - SDS. Brasília.

MITTERMEIER, A. R.; MEYERS, N.; GIL P. R.; MITTERMEIER, C. G. (2000). Hotspots: Earth's biologically richest and most endangered terrestrial ecoregions. CEMEX/Conservation International. Ed. Agrupación Sierra Madre.

NITSCH, M. (1998). Planejamento sem rumo. Avaliação crítica da metodologia do "Zoneamento Ecológico-Econômico" nos estados da Amazônia brasileira. Parecer elaborado para a Secretaria de Planejamento do Estado de Rondônia - Projeto de Cooperação Técnica PNUD/PLANAFLORO. Porto Velho/RO. Obtido em www.rondonia.ro.gov.br (21/08/2001). 
OLIVEIRA, J. B. de; PRADO, H. do (1984). Levantamento pedológico semidetalhado do Estado de São Paulo: Quadrícula de São Carlos. II Memorial descritivo. Campinas, 188 p. Instituto Agronômico de Campinas. Boletim Técnico $n^{\circ} 98$.

PARIZZI, M. G. et al (2001). Environment, tourism and land use planning Riachinho Basin - Brazil. Environmental Management and Health, vol. 12, n. ${ }^{\circ}$, p. 57-66. MCB University Press.

PONÇANO, W. L. et al. (1981). Mapa geomorfológico do Estado de São Paulo. Série Monografias. São Paulo. Instituto de Pesquisas Tecnológicas do Estado de São Paulo - IPT. Divisão de Minas e Geologia Aplicada.

RANIERI, S. (1996). Avaliação de métodos e escalas de trabalho para determinação de risco de erosão em bacia hidrográfica utilizando sistema de informações geográficas (SIG). São Carlos, 129 p. Dissertação (Mestrado). Escola de Engenharia de São Carlos, Universidade de São Paulo.

RANIERI, V. E. L (2000). Discussão das potencialidades e restrições do meio como subsídio para o zoneamento ambiental: o caso do município de Descalvado (SP). São Carlos, 87 p. Dissertação (Mestrado). Escola de Engenharia de São Carlos, Universidade de São Paulo.

RONDÔNIA (ESTADO) (2001). Zoneamento Sócioeconômico-Ecológico. Governo do Estado de Rondônia. www.rondonia.ro.gov.br (08/04/2001).

de ROO, G. (2000). Current research projects of theme "Shaping the built environment'. Faculty of Spatial Sciences. University of Gröening, Netherlands. http://www.frw.rug.nl/plan/plan2uk.htm(08/01/2001).

SACHS, I. (1993). Estratégias de transição para o século XXI: desenvolvimento e meio ambiente. São Paulo. 103 p. Estúdio Nobel, FUNDAP.

SAE/PR (2000). Coordenação-Geral de Macrozoneamento Geopolítico e Econômico do Território Nacional (COGEC). Secretaria de Assuntos Estratégicos da Presidência da República. Brasília. http://www.sae.gov.br /cogec.html (12/12/2000).

SÁNCHEZ, L. E. (2001). Desengenharia: o Passivo Ambiental na Desativação de Empreendimentos Industriais. São Paulo, 254 p. EDUSP. 
SANTOS, M. (1993). Subsídios para o planejamento conservacionista da bacia hidrográfica do ribeirão do Feijão (São Carlos, Itirapina e Analândia, SP). São Carlos, 222 p. Vol. I. Dissertação (Mestrado). Escola de Engenharia de São Carlos, Universidade de São Paulo.

SANTOS, M. A.; NASCIMENTO, J. A. S. (1992). A inserção da variável ambiental no planejamento do território. Revista da Administração Pública. Vol. 26, $\mathrm{n}^{\circ} 1$. p. 6-12.

SÃO PAULO (ESTADO) (1991). Manual para adequação ambiental na implantação de distritos industriais. Secretaria de Meio Ambiente. Coordenadoria de Planejamento Ambiental. $1^{a}$ edição. São Paulo, 55 p. CETESB

SÃO PAULO (ESTADO) (1995). Macrozoneamento das bacias dos rios MogiGuaçu, Pardo e Médio Grande - questões sócio-ambientais regionais. Volume 1. São Paulo. Secretaria de Meio Ambiente / Secretaria da Agricultura e Abastecimento / Secretaria de Economia e Planejamento.

SÃO PAULO (ESTADO) (1997). Cerrado: bases para a conservação e uso sustentável das áreas de cerrado do Estado de São Paulo. São Paulo, 55 p. Secretaria de Estado do Meio Ambiente.

SATO, M.; SANTOS, J. E. (1999). Agenda 21 em sinopse. São Carlos, 60p. EdUFSCar.

SÉ, J. A. S. (1992). O Rio do Monjolinho e sua Bacia Hidrográfica como integradores de sistemas ecológicos: um conjunto de informações para o início de um processo de Pesquisas Ecológicas, de Educação, Planejamento e Gerenciamento Ambientais a longo prazo. São Carlos. Dissertação (Mestrado). Escola de Engenharia de São Carlos, Universidade de São Paulo.

SEMADS (2000). Projeto de Zoneamento Ecológico-Econômico. Secretaria de Estado de Meio Ambiente e Desenvolvimento Sustentável. Rio de Janeiro. Disponível em http://www.semads.rj.gov.br/zee.htm. (16/12/2000).

SOUZA, H. de (1992). Ecologia e Democracia: Duas Vertentes Questionam o Desenvolvimento. In: Acselrad, H. (org). (1992). Meio Ambiente e Democracia. Rio de Janeiro. IBASE, p. 11-17.

SOUZA, M. P. (2000). Instrumentos de Gestão Ambiental: Fundamentos e Prática. São Carlos. 112 p.Ed. Riani Costa. 
VIEIRA, P. F. (2001). Meio Ambiente, Desenvolvimento e Planejamento. In: Meio Ambiente, Desenvolvimento e Cidadania: desafios para as Ciências Sociais. Pág. 45-98. 3ª edição. São Paulo, Ed. Cortez; Florianópolis, UFSC. 220 p.

WCED (1987). Our Commom Future. World Commission on Environment and Development. Oxford, 400 p. Oxford University Press.

ZHOU, C. (1998). GIS monitors our fragile Earth. GIS World. V. 11, n. ${ }^{\circ} 10$, Outubro, 1998, Fort Collins - CO - USA. 